\title{
Characterization of lipids and the protein co-products from various food sources using a one-step organic solvent extraction process
}

\author{
Alleda Rose \\ amrose@mix.wvu.edu
}

Follow this and additional works at: https://researchrepository.wvu.edu/etd

Part of the Entomology Commons, Food Chemistry Commons, and the Food Processing Commons

\section{Recommended Citation}

Rose, Alleda, "Characterization of lipids and the protein co-products from various food sources using a one-step organic solvent extraction process" (2019). Graduate Theses, Dissertations, and Problem Reports. 3944.

https://researchrepository.wvu.edu/etd/3944

This Thesis is protected by copyright and/or related rights. It has been brought to you by the The Research Repository @ WVU with permission from the rights-holder(s). You are free to use this Thesis in any way that is permitted by the copyright and related rights legislation that applies to your use. For other uses you must obtain permission from the rights-holder(s) directly, unless additional rights are indicated by a Creative Commons license in the record and/ or on the work itself. This Thesis has been accepted for inclusion in WVU Graduate Theses, Dissertations, and Problem Reports collection by an authorized administrator of The Research Repository @ WVU. For more information, please contact researchrepository@mail.wvu.edu. 
Characterization of lipids and the protein co-products from various food sources using a one-step organic solvent extraction process

\author{
Alleda Rose \\ A thesis submitted to the \\ Davis College of Agriculture, Forestry and Consumer Sciences \\ at West Virginia University \\ in Partial Fulfillment of the Requirements \\ for the degree of \\ Master of Science \\ in
}

Nutritional and Food Sciences

Kristen E. Matak, Ph. D., Chair

Jacek Jaczynski, Ph.D.

Janet Tou, Ph. D

Department of Animal and Nutritional Sciences

Morgantown, West Virginia

2018

Keywords: One-step lipid extraction, Defatting techniques, Insect powders

Copyright 2018 Alleda Rose 


\title{
ABSTRACT \\ Characterization of lipids and the protein co-products from various food sources using a one-step organic solvent extraction process
}

\begin{abstract}
Alleda Rose
Traditional lipid extraction methods are labor intensive and time-consuming so interest in one-step methods using various organic solvents are gaining in popularity. Extraction efficiency depends heavily on the solvents used yet comparisons between different solvents are lacking. Defatting techniques are commonly used to concentrate crude protein and may be useful for enhancing protein content in food sources. The objective of this research was to 1) determine the lipid extraction efficiencies of hexane $(\mathrm{H}), 3: 2$ hexane-isopropanol (HI), chloroform (C), 2:1 chloroform-methanol (CM), and methyl-tert-butyl-ether (MTBE) using a one-step organic solvent lipid extraction method on whole insect, egg yolk, and krill powders and 2) characterize the comparison of the remaining defatted protein. Hexane $(\mathrm{H}), 3: 2$ hexane-isopropanol (HI), chloroform (C), and methyl-tert-butyl-ether (MTBE) were used as the extraction solvents and extraction efficiencies were compared to 2:1 chloroform-methanol (CM). A 1:10 sample:solvent ratio was vortexed, stirred for $15 \mathrm{~min}$, centrifuged for $10 \mathrm{~min}$ at $900 \mathrm{x} \mathrm{g}$ to remove lipid layer which was filtered and dried. Extraction efficiency was calculated and fatty acid composition (GCFID) and lipid classes (TLC) were determined on all extracted lipids. Proximate composition, SDS-PAGE, amino acid profile, and $\mathrm{pH}$ solubility were performed on the defatted powder following lipid extraction. The lipid extractions efficiencies were best $(\mathrm{p}<0.05)$ when $\mathrm{CM}$ was used as the organic solvent for cricket $(69.32 \pm 2.61 \mathrm{~g} / 100 \mathrm{~g})$, locust $(93.03 \pm 12.09 \mathrm{~g} / 100 \mathrm{~g})$, and krill $(19.15 \pm 1.93 \mathrm{~g} / 100 \mathrm{~g})$; however when compared to the rest of the organic solvents, CM had the lowest $(34.96 \pm 0.03 \mathrm{~g} / 100 \mathrm{~g})$ and MTBE had the highest $(59.65 \pm 2.48 \mathrm{~g} / 100 \mathrm{~g})$ lipid extraction
\end{abstract}


efficiency $(\mathrm{p}<0.05)$ for silkworm. The lipid extractions were best $(\mathrm{p}<0.05)$ when $\mathrm{H}$ was the organic solvent for locust $(75.14 \pm 0.10 \mathrm{~g} / 100 \mathrm{~g})$ and egg yolk $(34.44 \pm 0.16 \mathrm{~g} / 100 \mathrm{~g})$. Composition data showed that of the solvents tested, H and MTBE were the most effective at removing lipid and concentrating protein $(\mathrm{p}<0.05)$ in the defatted insect powder; CM was the least effective organic solvent. When the lipids were extracted from cricket, locust, silkworm, and krill using HI, H, and $\mathrm{CM}$ there was minimal degradation ( $\mathrm{p}>0.05$ ) of TG, $\mathrm{PL}$, and CHL when compared to the original powders. None of the organic solvents tested produced a lipid class similar to the egg yolk lipid classes that are reported in literature; however, minimal changes were found in the fatty acid profile of recovered lipid from cricket and krill. Extraction of locust and egg yolk lipid resulted in the greatest $(\mathrm{p}<0.05)$ alteration to the fatty acid profile. Protein characterization of recovered defatted insect powders via SDS-PAGE indicate high amounts of cuticle protein, actin, hemocyanin, and myosin. The amino acid concentrations of all defatted insect powders were increased except when $\mathrm{C}$ and $\mathrm{CM}$ were used to defat the silkworm powder. When defatted using MTBE and $\mathrm{H}$, defatted cricket powder was most soluble at $\mathrm{pH} 11$ and defatted locust and silkworm at $\mathrm{pH} 12$ which is consistent with the greatest solubility of the insect powders at $\mathrm{pH}$ 12. In conclusion, a one-step lipid extraction using $\mathrm{H}$ and MTBE have potential for lipid extraction and defatting powders; however more studies are needed to measure the protein quality and functionality to determine the benefits of these one-step extraction methods. 


\section{ACKNOWLEDGEMENTS}

This project was funded by the US Department of Agriculture Hatch Program Project \#WVA 00722 .

I would like to thank my advisor, Dr. Kristen E. Matak for her guidance and encouragement not only in my Master's but throughout my undergraduate degree as well. I appreciate all of her support because I could not have done it without her.

Thank you to my committee members, Dr. Jacek Jaczynski and Dr. Janet Tou for always having an open office door. I would like to thank the faculty and staff in the Animal and Nutritional Sciences Department at West Virginia University for their continuous support.

A special thank you to Casey Showman, Susan Slider, and Derek Warren for their guidance, training, and support in completing this project. I appreciate the hours you spent assisting me in the laboratory as well as providing honest and critical feedback.

Finally, my deep appreciation to my family and boyfriend for supporting and encouraging me throughout my education. 


\section{TABLE OF CONTENTS}

ABSTRACT $\quad$ ii

ACKNOWLEDGEMENTS $\quad$ iv

LIST OF TABLES

LIST OF FIGURES $\quad$ viii

CHAPTER I 1

$\begin{array}{ll}\text { INTRODUCTION } & 1\end{array}$

$\begin{array}{ll}\text { REFERENCES } & 3\end{array}$

CHAPTER II $\quad 4$

$\begin{array}{ll}\text { REVIEW OF LITERATURE } & 4\end{array}$

$\begin{array}{ll}\text { Extraction Methods } & 4\end{array}$

Extraction Efficiency $\quad 4$

Extraction Time $\quad 5$

Organic Solvents $\quad 5$

Defatting Techniques $\quad 6$

Protein Content $\quad 6$

$\begin{array}{ll}\text { Protein Solubility } & 7\end{array}$

$\begin{array}{ll}\text { REFERENCES } & 10\end{array}$

\begin{tabular}{ll} 
CHAPTER III & 13 \\
\hline
\end{tabular}

$\begin{array}{ll}\text { INTRODUCTION } & 16\end{array}$

$\begin{array}{ll}\text { MATERIALS AND METHODS } & 17\end{array}$

$\begin{array}{ll}\text { RESULTS AND DISCUSSION } & 20\end{array}$

Extraction Efficiency $\quad 20$

$\begin{array}{ll}\text { Lipid Classes } & 22\end{array}$

Fatty Acid Profile $\quad 22$

$\begin{array}{ll}\text { CONCLUSION } & 23\end{array}$ 
$\begin{array}{ll}\text { REFERENCES } & 24\end{array}$

\begin{tabular}{lr} 
CHAPTER IV & 32 \\
\hline
\end{tabular}

$\begin{array}{ll}\text { INTRODUCTION } & 34\end{array}$

MATERIALS AND METHODS

$\begin{array}{ll}\text { RESULTS AND DISCUSSION } & 37\end{array}$

Proximate Composition $\quad 37$

$\begin{array}{ll}\text { SDS-PAGE } & 38\end{array}$

Essential Amino Acid Composition $\quad 39$

Protein Solubility $\quad 39$

$\begin{array}{ll}\text { CONCLUSION } & 40\end{array}$

$\begin{array}{ll}\text { REFERENCES } & 41\end{array}$

\begin{tabular}{lr} 
CHAPTER V & 48 \\
\hline
\end{tabular}

$\begin{array}{ll}\text { APPENDIX } & 48\end{array}$ 


\section{LIST OF TABLES}

\section{CHAPTER III}

TABLE 1: Lipid extraction efficiencies $(\mathrm{g} / 100 \mathrm{~g})$ following one-step organic solvent extraction with various organic solvents.

TABLE 2: Thin layer chromatography (TLC) densitometry analysis of lipid classes (\%) extracted using a one-step organic solvent extraction with various organic solvents.

TABLE 3: Fatty acid composition (\%) of insect powders (cricket, locust, and silkworm) and extracted lipid following a one-step organic solvent extraction with various organic solvents.

\section{CHAPTER IV}

TABLE 1: Proximate composition of defatted insect powders following one-step extraction with various organic solvents. Ash, crude protein and crude lipid were measured as g/100g, dry basis.

TABLE 2: Essential amino acid composition $(\mathrm{g} / 100 \mathrm{~g})$ of defatted insect powders following one-step extraction with various organic solvents.

TABLE 3: Protein Solubility (\%) of original insect and defatted insect powders

\section{CHAPTER V}

TABLE 1: Amino acid composition (g/100g) of spent insect powders following one-step organic solvent extraction with various organic solvents

TABLE 2: Protein Solubility (\%) of original insect and spent insect powders

TABLE 3: Proximate composition (g/100g, dry basis) of original and spent insect powders following protein solubility

TABLE 4: Amino acid composition ( $\mathrm{g} / 100 \mathrm{~g}$ ) of original and spent insect powders following protein solubility

TABLE 5: SDS-page densitometry analysis of protein (\%) from spent cricket, locust and silkworm powder following one-step organic solvent extraction with various organic solvents 


\section{LIST OF FIGURES}

\section{CHAPTER III}

FIGURE 1. Separated lipid classes of cricket (A), locust (B), silkworm (C) powders following a one-step organic solvent extraction with various organic solvents.

FIGURE 2. Separated lipid classes of egg yolk (A) and krill (B) powders following a one-step organic solvent extraction with various organic solvents.

\section{CHAPTER IV}

FIGURE 1. SDS-Page gels of cricket (A), locust (B), and silkworm (C) powders following a onestep organic solvent extraction with various organic solvents.

FIGURE 2: Protein solubility of original and defatted cricket powder in solutions with varying $\mathrm{pH}$

FIGURE 3: Protein solubility of original and defatted locust powder in solutions with varying $\mathrm{pH}$

FIGURE 4: Protein solubility of original and defatted silkworm powder in solutions with varying $\mathrm{pH}$

\section{CHAPTER V}

FIGURE 1: Protein solubility of original insect powders in various $\mathrm{pH}$ conditions

FIGURE 2: Protein solubility of spent insect powders in various $\mathrm{pH}$ conditions

FIGURE 3. SDS-Page gels of initial insect and spent insect powders following protein solubility 


\section{Chapter I}

\section{Introduction}

Currently Folch and Soxhlet lipid extraction techniques are considered gold standards to extract lipids from their sources and most commonly used for laboratory and industrial purposes; however, these techniques are limited by the type of organic solvents that are used, they can be destructive to the lipid fractions, both methods are time consuming, and these methods are not food grade. A more efficient extraction process is needed. Now interest in one-step organic solvent extractions with various organic solvents are increasing due to being less labor intensive, less time consuming, and are not specific for a particular organic solvent (Gigliotti et al. 2011). Though a one-step organic solvent extraction is flexible in terms of the organic solvents that can be used, the polarity of the organic solvents must be appropriate to the types of lipids being extracted to provide an efficient extraction. The term "like dissolves like" holds true, thus polar solvents are best for dissolving polar reactants, and nonpolar solvents are best for dissolving nonpolar reactants (Cerkowniak et al., 2013). A polar solvent has a large dipole moment, they contain bonds between atoms with very different electro negativities such as oxygen and hydrogen; an example would be methanol which is a part of the alcohol organic compound class. A nonpolar solvent contains bonds between atoms with similar electro negativities, such as carbon and hydrogen; an example is hexane which is a part of the alkane organic compound class (Covington et al.,1973).

When comparing a one-step organic solvent extraction method to Folch and Soxhlet methods, two studies (Gigliotti et al., 2011; Xie et al., 2017) found no significant differences between the results when extracting lipid from krill; therefore, recommended a one-step organic solvent extraction since it was less time consuming and produced a comparable lipid efficiency. Following a one-step organic solvent lipid extraction from krill Gigliotti and colleagues (2011) analyzed the defatted krill powder and found that it was composed mainly of protein so they concluded that a one-step organic solvent extraction may be an efficient defatting technique. Defatting techniques are used to concentrate protein by removal of lipid.

One-step organic solvent extractions with various organic solvents may prove effective as a defatting technique by removing high amounts of lipid and leaving a high-quality protein. Therefore, the aim of this research was to (a) determine if a one-step organic solvent lipid extraction using hexane $(\mathrm{H}), 3: 2$ hexane-isopropanol (H:I), chloroform (C), 2:1 chloroformmethanol (C:M), and methyl-tert-butyl-ether (MTBE) could produce high lipid extraction 
efficiencies from various food sources and (b) analyze the composition of the defatted protein leftover from the food source after they had undergone a one-step organic solvent lipid extraction method. 


\section{References}

1. Cerkowniak, M., Puckowski, A., Stepnowski, P., \& Golebiowski, M. 2013. The use of chromatographic techniques for the separation and the identification of insect lipids. Journal of Chromatography B. 937; 67-78.

2. Covingtion, A.K., Dickinson, T. 1973. Physical chemistry of organic solvent systems. Plenum Press. 1-7.

3. FAO. 10-14 November 2008. 2010. Fats and fatty acids in human nutrition: report of an expert consultation. Geneva, Rome: Food and Agriculture Organization of the United Nations.

4. Gigliotti, J., Davenport, M.P., Beamer, S.K., Tou, J.C., \& Jaczynsiki, J. 2011. Extraction and characterization of lipids from Antarctic krill (Euphausia superba). Food Chemistry. $125 ; 1028-1036$.

5. Xie, D., Jin, J., Sun, J., Liang, Li., Wang, X., Zhang, W., Wang, X., \& Jin, Q. 2017. Comparison of solvents for extraction of krill oil from krill meal: Lipid yield, phospholipids content, fatty acids composition and minor components. Food Chemistry. 233; 434-441. 


\section{Chapter II}

\section{Review of Literature}

\section{Extraction methods}

Lipids are extracted using various methods with solvents. Common methods for lipid extraction are the Folch method and Soxhlet method. The Folch method is considered the gold standard of lipid extraction for laboratory applications. This method consists of a two-step extraction process with a ternary solvent system (2:1 chloroform-methanol) by first extracting molecules and then separating them into an organic and polar phases. This method is commonly used for total lipid extraction from tissues (Folch et al., 1957). The Folch method uses polar and nonpolar solvents in the biphasic solvent system to remove membrane bound lipids, such as phospholipids, but not triglycerides. Limitations to this method are the lipid extracted is not food grade and therefore cannot be used in food products, the method requires a specific organic solvent, and that it favors the extraction of phospholipid. On the other hand, the Soxhlet method is commonly used as a semi-continuous method used for the extraction of lipids from dried foods in laboratory and industry settings. According to the Soxhlet procedure (AOAC, 1995), oil and fat from solid material are extracted by repeated washing with an organic solvent, usually hexane or petroleum ether, under reflux in a special glassware. Hexane is considered a food grade organic solvent thus the lipid produced by this method can be used for human consumption however there are limitations such as 1) the method requires specific organic solvents, 2) it is destructive to the extracted lipid, and 3) it is time consuming. Due to the limitations of both methods interest in onestep extraction methods are increasing because they tend to be less labor intensive, less time consuming, and are not specific for a certain organic solvent (Gigliotti et al. 2011). One-step extraction methods typically entail mixing a ratio of sample to solvent on a stir plate, with stirring time dependent on the type of sample, and then centrifugation to separate lipids.

1.1 Extraction Efficiency. When comparing the one-step organic solvent extraction method to the Folch and Soxhlet methods, studies have shown that the lipid yields are relatively similar (Gigliotti et al. 2011). Gigliotti and colleagues (2011) extracted the lipid from krill by a one-step organic solvent extraction method using a 1:1 mixture of acetone:ethanol at the following ratios: 1:6, 1:9, 1:12, 1:30 krill oil:solvent (weight to volume). Results were compared to Folch and Soxhlet extraction efficiencies. The greatest lipid yields were achieved using the one-step organic solvent extraction method at 1:12 and 1:30 ratios $(\mathrm{p}<0.05)$ and there were no significant 
differences between the Folch and Soxhlet methods and the 1:6 and 1:9 ratios. Thus, the authors concluded that the one-step organic solvent extraction method was simpler, less time consuming and labor intensive, and had greater lipid yields (Gigliotti et al., 2011). In a study by Xie and colleagues (2017) lipid was extracted from krill meal by a one-step extraction method using a 1:12 ratio (krill meal:organic solvent) with various organic solvents (ethanol, isopropanol, acetone, ethyl acetate, isohexane, and n-hexane). Results were also compared to the Folch and Soxhlet methods. In this study, it was found that the Folch method produced the highest lipid yield; however, there were no significant differences $(\mathrm{p}<0.05)$ between the organic solvent isopropanol and the Soxhlet method. In addition, isopropanol was used as the organic solvent which resulted in more phospholipids being extracted than the Soxhlet method. Thus, the authors concluded that the one-step organic solvent extraction method using isopropanol should be considered for industrial production of krill oil (Xie et al., 2017).

1.2 Extraction time. The success of a one-step extraction method using organic solvents depend heavily on the length of extraction time. Gigliotti and colleagues (2011) reported that for krill meal an extraction time of 140 min produced the greatest extraction efficiencies $(12 \mathrm{~g} / 100 \mathrm{~g})$ with a one-step extraction method with 1:1 acetone:ethanol at a 1:12 krill:solvent ratio. On the other hand, Baümler and colleagues (2010), extracted lipid from 10g sunflower collets (pressed sunflower cake) using a one-step extraction method with $180 \mathrm{~mL}$ hexane as the organic solvent (1:18 sunflower collet:solvent); the length of extraction times ranged from 0 to $270 \mathrm{~min}$ at 40, 50, and $60^{\circ} \mathrm{C}$. Results showed that a 30 min extraction time at $60^{\circ} \mathrm{C}$ produced the highest extraction efficiency (98.1\%) along with triglyceride extraction (99.5\%) and phospholipid extraction (66.5\%) (Baümler, 2010). Triglyceride and phospholipid extraction occurred very quickly at the beginning of the extraction and plateaued at $30 \mathrm{~min}$ for all temperatures. Therefore, Baümler and colleagues (2010) recommended an extraction of 30 min due to producing a high extraction efficiency for sunflower collet in a short time frame.

1.3 Organic Solvents. Lipids are soluble in organic solvents and the existing procedures for the extraction of lipids from source material usually involves selective solvent extraction. When choosing the appropriate solvent for any method, polarity of the sample and solvent defines how efficient the solvent will be in extracting the lipid (Cerkowniak et al., 2013). The term "like dissolves like" holds true, thus polar solvents are best for dissolving polar reactants, and nonpolar solvents are best for dissolving nonpolar reactants. A polar solvent has a large dipole moment, they 
contain bonds between atoms with very different electro negativities such as oxygen and hydrogen; an example would be methanol which is a part of the alcohol organic compound class. A nonpolar solvent contains bonds between atoms with similar electro negativities, such as carbon and hydrogen; an example is hexane which is a part of the alkane organic compound class (Covington et al.,1973).

Hexane is a hydrocarbon which is nonpolar and is a good solvent for lipids with low polarity, thus, triglycerides are very soluble, and phospholipids are moderately soluble in this solvent (Baümler et al., 2010). Hexane-isopropanol (3:2) is a mixture that incorporates nonpolar and polar aspects. The hexane is the nonpolar part that helps extract nonpolar lipids, while the isopropanol is polar enough to interact with polar lipids. A 3:2 ratio is often used because if there were more isopropanol the solvent would become too polar and result in inadequate lipid extraction. The lipid extracted using hexane-isopropanol (3:2) had no significant differences to when chloroform-methanol (2:1) was used, but the lipid extracted contain less non-lipid material, and it can be applied to a chromatographic column or thin-layer plate without fear of clogging the column (Markham et al., 2006). Chloroform is a chlorinated hydrocarbon and is a popular solvent for lipids with intermediate polarity, such as triglycerides, due to it being nonpolar (Covington et al.,1973). Chloroform-methanol (2:1) is the nonpolar/polar solvent used in the Folch extractions. This solvent mixture allows for the extraction of nonpolar lipids via chloroform while the methanol, which is polar, will extract the more polar membrane-associated lipids. A 2:1 ratio is used because if there was more methanol the solvent would become too polar and result in inadequate lipid extraction (Folch et al., 1957). MTBE is part of the alkyl ethers chemical class which is more polar than hydrocarbons, but less polar than alcohols, thus it will extract nonpolar and polar lipids. It will allow for a faster, cleaner lipid recovery due to its low-density, lipidcontaining organic phase forms the upper layer during phase separation which simplifies collection and minimizes lipid dripping losses. MTBE protocol delivers similar or better recoveries of species of most all major lipid classes compared with the Folch method using chloroform-methanol (Matyash et al., 2008).

\section{Defatting Techniques}

2.1 Protein Content. Defatting techniques are used to concentrate the crude protein amount in soybean, cottonseed, egg yolk, and insect powders. Hexane is the solvent most extensively used for the defatting soybeans. However, concerns about its effect on functionality, 
its availability, tighter emission restrictions, and safety have stimulated interest in alternative methods for defatting (Lusas et al., 1991; Gandhi et al., 2003). L'Hocine and colleagues (2006) investigated the efficacy of using ethanol and methanol to defat soybeans and compared the results to conventional hexane methods. Soybeans were grinded into a meal and then stirred with a solvent (hexane, ethanol or methanol; 1:1-1:3 ratio, w:v) for $30 \mathrm{~min}$. The mixture was decanted and the solvent layer was siphoned. The extraction was repeated 2 more times to achieve maximum defatting. For the final defatting step, the mixture (solvent plus meal) was filtered rinsed with fresh solvent and left overnight to dry at room temperature under a fume hood. L'Hocine and colleagues (2006) found the concentration of crude protein of the defatted soybean (85\%) was increased when hexane $(92.8 \%)$, ethanol $(96.0 \%)$, and methanol $(94.0 \%)(\mathrm{P}<0.05)$ were used as the organic solvents. However, the lipid content of the defatted soybean when using the organic solvents (hexane, ethanol, and methanol) were $0.9 \%, 0.7 \%$, and 1.6\%, respectively. Ash content of the defatted soybean were not significantly different: 3.0\% (hexane), 3.0\% (ethanol), and 3.1\% (methanol). Differences in the polarities of the solvents would explain the differences in their defatting efficiencies. Methanol, being more polar than ethanol and hexane would be less efficient in removing less polar lipids. Therefore, ethanol could potentially be a better alternative over methanol to hexane for defatting soybeans. Purschke and colleagues (2018) found that when defatting locust (Locusta migratoria) powder with hexane crude protein content increased $(65.87 \%$ to $82.26 \%$ ) and lipid content decreased (23.81\% to $3.27 \%$ ). Locust powder was defatted by mixing locust powder with hexane at a ratio of $1: 5 \mathrm{w}: \mathrm{v}$ and stirred continuously for $27 \mathrm{~h}$ at room temperature. After $1 \mathrm{~h}$ of rest, the hexane-fat phase was separated via manual decantation then dried in a vacuum drying chamber.

While defatting techniques have shown to concentrate the crude protein, the use of organic solvents may affect the types of protein present as well as their molecular size. Chung and colleagues (1991) defatted egg yolk powder by a two-step organic solvent extraction using hexane, chloroform, methanol, isopropanol, and ethanol. SDS-page was used to separate soluble proteins by molecular weight. The results showed that there were differences in the protein bands of the ethanol extracted proteins when compared to the original powder. The other organic solvents showed similar SDS-page patterns to that of the original egg yolk powder.

2.2 Protein Solubility. Protein solubility is a critical functional property and one of the first things determined before the development of a new protein ingredient (McCarthy et al., 
2013). Solubility is when equilibrium exists between hydrophilic and hydrophobic interactions. The solubility of the protein is related to $\mathrm{pH}$ and ionic strength. Solutions with differing $\mathrm{pH}$ will result in various stages of protein unfolding, leading to solubility differences (Warren et al., 2017). Solutions with various ionic strengths have concentration differences of charged ions, which will interact with oppositely charged amino acid groups. Increased interactions of charged ions would decrease water interactions, leading to precipitation of proteins (Lopez-Enriquez et. al., 2015). Solubility can be influenced by organic solvents used in defatting techniques. Rezig and colleagues (2013) founded when defatting pumpkin seed flour with pentane and 3:1 chloroform-methanol (flour/solvent: $1: 10 \mathrm{w} / \mathrm{v}$ ) the defatted pumpkin seed flour by chloroformmethanol produced a protein solubility of $55 \%$ whereas defatted pumpkin seed flour by pentane $88 \%$ at a $\mathrm{pH}$ of 10 . Proteins can be partly denatured by chloroform-methanol in alkaline conditions. Nonpolar organic solvents such as pentane or hexane are preferred for defatting techniques to avoid protein denaturation (Rezig et al., 2013).

To enhance protein solubility other extrinsic factors can be incorporated such as salt concentration and time. Yi and colleagues (2014) achieved 100\% protein solubility of T.molitor at a $\mathrm{pH} 10$ with the addition of $0.1 \mathrm{M} \mathrm{NaCl}$. The studies mentioned previously (Purschke et al., 2018; Bubler et al., 2016) achieved 100\% solubility at a pH 9 and $95 \%$ solubility at a pH 2 by increasing the lipid extraction of the locust powder to $27 \mathrm{~h}$ and using a two-step organic solvent lipid extraction of the yellow meal worm larvae powder.

Amino acid solubility is dependent on both the polar and nonpolar portions of the molecule therefore organic solvents used in defatting techniques will effect amino acid solubility (Needham, 1970). Teh and colleagues (2014) stated findings when defatting hemp meal with hexane. The essential amino acid profile of the defatted hemp meal was greater than $(\mathrm{P}<0.0001)$ than the untreated hemp meal. This indicates that the presence of lipid likely interferes with the hydrolysis of the amino acids during analysis of the untreated hemp meal.

The aim of this literature review was (a) to investigate the impact of various organic solvents on lipid extraction efficiencies using a one-step method and (b) to investigate the effects of these strategies on protein content and solubility of resulting defatted protein powders. It was shown that the organic solvents used and extraction times will impact extraction efficiency, protein content, and protein solubility of the powders; therefore, more research is needed to evaluate lipid 
and protein content as well as composition of protein powder defatted using one-step organic solvent lipid extraction methods. 


\section{References}

1. Association of Official Analytical Chemists (AOAC). 1995. Offical Methods of Analysis, $16^{\text {th }}$ ed.; Association of Offical Analytical Chemists: Washington, DC.

2. Baülmer, E., Guillermo, H., \& Carelli, A.A. 2010. Solvent extraction: kinetic study of major and minor compounds. JAOCS. 12; 1489-1495.

3. Bubler, S., Rumpold, B., Jander, E., Rawel, H., \& Schluter, O. 2016. Recovery and technofunctionality of flours and proteins from two edible insect species: meal worm (Tenebrio molitor) and black soldier fly (Hermetia illucens) larvae. Heliyon, 2(12).

6. Cerkowniak, M., Puckowski, A., Stepnowski, P., \& Golebiowski, M. 2013. The use of chromatographic techniques for the separation and the identification of insect lipids. Journal of Chromatography B. 937; 67-78.

7. Chung, S., \& Ferrier, L.K. 1999. Partial lipid extraction of egg yolk powder: effects on emulsifying properties and soluble protein fractions. Journal of Food Science. 56; 5.

8. Covingtion, A.K., Dickinson, T. 1973. Physical chemistry of organic solvent systems. Plenum Press. 1-7.

4. Folch, J.,\& Lees, M., Sloane, S. A simple method for isolation and purification of total lipids from animal tissues. 1957. Journal of Biological Chemistry. 226; 497-509.

5. Gandhi, A.P, Joshi, K.C., Kaushalendra, J., \& Parihar, V.S. 2003. Studies on alternative solvents for extraction of oil-soybean. Int J Food Sci Technol 38 (3): 369-75.

6. Gigliotti, J., Davenport, M.P., Beamer, S.K., Tou, J.C., \& Jaczynsiki, J. 2011. Extraction and characterization of lipids from Antarctic krill (Euphausia superba). Food Chemistry. $125 ; 1028-1036$.

7. JMP, Version 13 SAS Institute Inc., Cary, NC, 1989-2017.

8. L'Hocine, L., Boye, J.I., \& Arcand, Y. 2006. Composition and functional properties of soy protein isolates prepared using alternative defatting and extraction procedures. Journal of Food Science. 71;3.

9. Lopez-Enriquez, R. L., Ocano-Higuera, V. M., Torres-Arreola, W., Ezquerra-Brauer, J. M., \& Marquez-Rios, E. 2015. Chemical and Functional Characterization of Sarcoplasmic Proteins from Giant Squid (Dosidicus gigas) Mantle. Journal of Chemistry, 2015, 1-10. 
10. Lusas, E.W., Watkins, L.R, \& Rhee, K.C. 1991. Isopropyl alcohol to be tested as solvent. Inform 2:970-3.

11. Markham, J. E., Li, J., Cahoon, E.B, \& Jaworski, J.G. 2006. Separation and identification of major plant sphingolipid classes from leaves. J Biol Chem. 281(32); 22684-94.

12. Matyash, V., Liebisch, G., Kurzchalia, T.V., Shevchenko, A., \& Schwudke, D. 2008. Lipid extraction by methyl-tert-butyl ether for high-throughput lipidomics. J Lipid Res. 49(5); 11371146.

13. McCarthy, A., Ocallaghan, Y.C., \& Obrien, N.M. 2013. Protein hydrolysates from agricultural crops-Bioactivity and potential for functional food development. Agriculture. $3(1) ; 112-130$.

14. Needham, T. The solubility of amino acids in various solvent systems. Open Access Dissertations. Paper 159.

15. Purschke, B., Tanzmeister, H., Meinlschmidt, P., Baumgarter, S., Lauter, K., \& Jager, H. 2018. Recovery of soluble proteins from migratory locust (Locusta migratoria) and characterization of their compositional and techno-functional properties. Journal of Food Research International. 106; 271-279.

16. Rezig, L., Chibani, F., Chouaibi, M., Dalgalarrondo, M., \& Hessini, K. 2013. Pumpkin (Curcurbita maxima) seed proteins: sequential extraction processing and fraction characterization. Journal of Agricultural and Food Chemistry. 61(32); 7715-7721.

17. Teh, S., Carne, A., Bekhit, A., \& Birch, E.J. 2014. Effect of the defatting process, acid and alkali extraction on the physicochemical and functional properities of hemp, flax, and canola seed cake protein isolates. Food Measure. 8; 92-104.

18. Warren, D., Paker, I., Jaczynski, J., Tou, J., \& Matak, K. 2017. Characterization of soluble proteins recovered from silver carp: Impact of protein recovery processing temperature on nutritional quality and physical characteristics of silver carp soluble protein powders. EDT Thesis WVU.

19. Xie, D., Jin, J., Sun, J., Liang, Li., Wang, X., Zhang, W., Wang, X., \& Jin, Q. 2017. Comparison of solvents for extraction of krill oil from krill meal: Lipid yield, phospholipids content, fatty acids composition and minor components. Food Chemistry. $233 ; 434-441$. 
20. Yi, L., Lakemond, C.M.M., Sagis, L.M.C., Eisner-Schadler, V., van Huis, A., \& van Boekel, A.J.S. 2013. Extraction and characterization of protein fractions from five insect species. Food Chemistry. 141 (4); 3341-3348. 


\section{Chapter III}

Extraction of lipids from insect, krill, and egg yolk powders using a one-step organic solvent extraction process

Alleda Rose, Jacek Jaczynski* and Kristen Matak*

Division of Animal and Nutritional Sciences, PO Box 6108, West Virginia University, Morgantown, WV, USA

*Corresponding Authors:

Dr. Kristen Matak and Dr. Jacek Jaczynski

Contact phone: 304-293-1908; 304-293-1893

Fax: 304-293-2232

Email: kristen.matak@mail.wvu.edu;jacek.jaczynski@mail.wvu.edu

Choice of journal section where article should appear: 


\section{Abstract}

Traditional lipid extraction methods are labor intensive and time-consuming so interest in one-step methods using various organic solvents are increasing. Extraction efficiency depends heavily on the solvents used yet comparisons between different solvents are lacking. The aim of this study was to compare the composition and extraction efficiency of lipids separated from insect, krill, and egg yolk powders by a one-step organic solvent extraction process using different solvents and combinations. Hexane (H), chloroform (C), methyl-tert-butyl ether (MTBE), and 3:2 hexaneisopropanol (HI) were used as the extraction solvents and extraction efficiencies were compared to 2:1 chloroform-methanol (CM). A 1:10 sample:solvent ratio was vortexed, stirred for 15 min, centrifuged $10 \mathrm{~min}$ at $900 \mathrm{x}$ g to remove lipid layer which was filtered and dried. Extraction efficiency was calculated and fatty acid composition (GC-FID) and lipid classes (TLC) were determined on all the extracted lipids. The lipid extractions efficiencies were best $(\mathrm{P}<0.05)$ when $\mathrm{CM}$ was used as the organic solvent for cricket $(69.32 \pm 2.61 \mathrm{~g} / 100 \mathrm{~g})$, locust $(93.03 \pm 12.09 \mathrm{~g} / 100 \mathrm{~g})$, and krill $(19.15 \pm 1.93 \mathrm{~g} / 100 \mathrm{~g})$; however, when compared to the rest of the organic solvents, CM had the lowest $(34.96 \pm 0.03 \mathrm{~g} / 100 \mathrm{~g})$ and MTBE had the highest $(59.65 \pm 2.48 \mathrm{~g} / 100 \mathrm{~g})$ lipid extraction efficiency $(\mathrm{P}<0.05)$ for silkworm. The lipid extractions were best $(\mathrm{P}<0.05)$ when $\mathrm{H}$ was the organic solvent for locust $(75.14 \pm 0.10 \mathrm{~g} / 100 \mathrm{~g})$ and egg yolk $(34.44 \pm 0.16 \mathrm{~g} / 100 \mathrm{~g})$. The differences in extraction efficiencies are likely due to the polarities of the organic solvents and lipid classes of the individual insects. All organic solvents extracted lipid classes that were most like the initial silkworm powder $(\mathrm{P}>0.05)$. $\mathrm{H}$ extracted lipid classes that were most like the initial cricket and silkworm powders $(\mathrm{P}>0.05)$. MTBE extracted lipid classes that were most like the initial powder for locust $(\mathrm{P}>0.05)$. $\mathrm{H}$ and $\mathrm{HI}$ both extracted amounts of triglycerides most like to that is reported in the literature for egg yolk powder $(\mathrm{P}>0.05)$. CM extracted the most like lipid classes reported in the literature for krill powder $(\mathrm{P}>0.05)$. Overall, MTBE was most effective at concentrating cholesterol for all powders $(\mathrm{P}<0.05)$. The polarities of the organic solvents will affect the amount of lipid classes extracted. The fatty acid profile for separated cricket and krill lipid was most like the original powders $(\mathrm{P}>0.05)$ when $\mathrm{CM}$ was used as the organic solvent; $\mathrm{HI}$ also produced a fatty acid profile for separated krill lipid most like the original powder ( $\mathrm{P}>0.05)$. However, MTBE, C, and $\mathrm{H}$ produced fatty acid profile for separated locust, silkworm, and egg yolk lipid most like the original powders $(\mathrm{P}<0.05)$. This method shows that while $\mathrm{H}, \mathrm{HI}$, and MTBE has potential for 
locust, silkworm, and egg yolk lipid extraction for human consumption, more studies need to be done to increase effectiveness and efficiencies of one-step extraction methods.

KEYWORDS: one-step organic solvent extraction, lipid extraction efficiency, lipid classes, fatty acid profile 


\section{Introduction}

Lipids are soluble in organic solvents and the existing procedures for the extraction of lipids from source material usually involves selective solvent extraction. The effectiveness of a solvent at lipid extraction is determined by the polarity of the sample and solvent (Cerkowniak et al., 2013). Organic solvents commonly used in lipid extraction include hexane (H), 3:2 hexaneisopropanol (HI), chloroform (C), 2:1 chloroform-methanol (CM), and methyl-tert-butyl-ether (MTBE). These organic solvents have nonpolar and polar properties thus can extract nonpolar (triglycerides) and polar (phospholipids) lipids. C and CM are toxic and therefore cannot be used when if the extracted lipids were used for human consumption; MTBE has a lower toxicity and is under testing to see if it can be a food grade solvent (EPA, 2016). $\mathrm{H}$ and HI have the lowest toxicity and are food grade organic solvents (FDA, 2018).

Common organic solvent lipid extraction methods include one-step organic solvent extraction, Soxhlet, and Folch. Folch and Soxhlet methods are considered gold standard applications and are the most commonly used; however, interest in one-step organic solvent extractions are increasing because they are less labor intensive and less time consuming (Gigliotti et al., 2011). One-step organic solvent extractions have produced comparable lipid extraction efficiencies, lipid classes and fatty acid profiles for krill meal when compared to Folch (Gigliotti et al., 2011).

Insect, krill, and egg yolk lipids can contribute to human nutrition by supplying energy and essential fatty acids. Insect and krill are underutilized for human consumption but are nutritious food sources. As a food source insects are rich in protein (60\% dry basis) and lipid (10-30\% dry basis) and provide a certain number of vitamins and minerals depending on species (Yi et al., 2013). A majority (up to 80\%) of the insect lipid content presents itself in the form of triglycerides, whereas phospholipids and cholesterol make up less than $20 \%$ and $3.6 \%$ of the lipid, respectively, with phospholipid varying the most between species, life stage, and diet (Tzompa-Sosa et al., 2014). Typically, insect lipid is relatively high in unsaturated C18 fatty acids including oleic (18:1 cis9), linoleic acid (18:2 cis9, 12), and linolenic acid (18:3cis 9, 12, 15) (DeFoliart, 1991). On the other hand, krill is a high-quality lipid (12-50\% dry basis) and protein source (60-78\% dry basis) (Bridges et al., 2010). A majority (greater than 40\%) of the krill lipid content presents itself in the form of phospholipids, whereas triglycerides range from 12-38\% and cholesterol makes up 30\% 
of the lipid content (Xie et al., 2017). The krill lipid is rich in omega-3 polyunsaturated fatty acids (n-3 PUFA) such as eicosapentaenoic (EPA, 20:n3) and docosahexaenoic (DHA, 22:6n3) acids (Gigliotti et al., 2011). Egg lipids are concentrated in the yolk; consisting of $64 \%$ and protein consisting of 32\% (Anton, 2007). Egg yolk lipid mainly consists of triglycerides (62\% dry basis) and phospholipids (33\% dry basis). Triglycerides are mostly occupied by palmitic, oleic, and linoleic fatty acids.

One-step organic solvent extraction strategies may prove effective for extracting lipid from food sources. Since insect, egg yolk, and krill are comprised of mostly triglycerides and phospholipids, organic solvents with nonpolar and polar properties need to be used to extract the lipid. Solvents that display these characteristics include hexane $(\mathrm{H}), 3: 2$ hexane-isopropanol (HI), chloroform (C), 2:1 chloroform-methanol (CM), and methyl-tert-butyl-ether (MTBE). Research on lipid extraction from insect, krill, and egg yolk powders using a one-step organic solvent extraction are limited; therefore, the objectives of this study were to determine lipid extraction efficiencies from insect, krill, and egg yolk powders using different organic solvents and characterize the composition of extracted lipids.

\section{Methods}

Cricket (Acheta domesticus), locust (Locusta migratoria), and silkworm pupae (Bombyx mori) powders were purchased from Thailand Unique (Nongsung, Thailand). Upon arrival, the insect powders were placed in $-80^{\circ} \mathrm{C}$ freezer until needed; during analyses, they were held at 2$5^{\circ} \mathrm{C}$ throughout the experiment. Freeze-dried Antarctic krill (Euphausia superba) was purchased from Rod's Reef (Dekalb, IL, USA), grinded into a powder, and held at $2-5^{\circ} \mathrm{C}$ throughout experiment. Egg yolk powder purchased from Magic Flavors (Seattle, WA, USA). Upon arrival, the egg yolk powder was placed in $-80^{\circ} \mathrm{C}$ freezer until needed; was held at $2-5^{\circ} \mathrm{C}$ throughout the experiment.

\subsection{One-step Organic Solvent Extraction}

A one-step lipid extraction was performed using hexane, hexane-isopropanol $(3: 2, v: v)$, chloroform, chloroform-methanol (2:1, v:v), and methyl-tert-butyl ether. Briefly, a $1 \mathrm{~g}$ sample was 
placed into a $35 \mathrm{~mL}$ Teflon-lined screw-capped Pyrex glass centrifuge test tube. Organic solvent was added $(9 \mathrm{~mL})$ to make a 1:10 ratio between sample/solvent. The test tube was vortexed for 60 $\mathrm{s}$ and then transferred to a $250 \mathrm{~mL}$ beaker with an aluminum top to prevent the solvent from evaporating. The beaker was placed on a stir plate with a proportional stir bar without heat for 15 min. The sample was transferred back to a $35 \mathrm{~mL}$ Teflon-lined screw-capped Pyrex glass centrifuge tube and centrifuged at $900 \mathrm{xg}(4000 \mathrm{rpm})$, at $10^{\circ} \mathrm{C}$ for $10 \mathrm{~min}$. The lower (lipid) layer was filtered through a 1-PS filter (Whatman, 2200-090, Buckinghamshire HP7, 9NA, UK) and collected into a second test tube. Before filtering, the filter paper was pre-rinsed 3 times with $5 \mathrm{~mL}$ 2:1 CM each to remove trace silicone residue. After filtering, the filter paper was discarded and the inside and outside of funnel was rinsed with a 5 3/4" disposable Pasteur pipette of 2:1 CM. Finally, samples were flushed under nitrogen gas (to dry sample) in a $60^{\circ} \mathrm{C}$ water bath for $60 \mathrm{~min}$ to remove organic solvents present. An aliquot was taken out and placed into a $14 \mathrm{~mL}$ test tube for thin layer chromatography. $125 \mu \mathrm{L}$ of internal standard (C19) was added to the rest of the samples, and then prepared for methylation.

\subsection{Lipid Extraction Efficiency}

Lipid extraction efficiency was measured to determine how much lipid can be extracted from each powder using different organic solvents. One gram of each original powder was weighed within a test tube. A second test tube was weighed before extracted lipid was put it in. Lipids were extracted via the one-step extraction described above. The extracted lipids were weighed in the test tube after being dried down with nitrogen gas, and percentage of lipid extraction efficiency was calculated:

Lipid Yield $(\%)=\frac{\text { After extraction weight }(g) \text {-test tube weight }(g)}{\text { Before extraction weight }(g)} X 100 \%$

Lipid Extraction Efficiency $(\%)=\frac{\text { Lipid Percent Extracted }}{\text { Percent Lipid Expected }}$ X $100 \%$

\subsection{Thin Layer Chromatography-Lipid Classes}

Thin Layer Chromatography was used to identify classes of lipid extracted from cricket powder, locust powder, silk worm powder, krill powder, and egg yolk powder. The extracted lipid was diluted in $1 \mathrm{~mL}$ of a 1:1 chloroform: methanol solvent. A $20 \mu \mathrm{L}$ aliquot of each sample was 
tested in duplicate and standards of reference of each class were placed on a 20 x $20 \mathrm{~cm}$ silica gel plate (Merck TLC silica gel $60 \mathrm{~W} F_{254} S$ plates with 60 A pore size, Darmstadt, Germany). After the plates were placed in a glass chamber with hexane/diethyl ether/ acetic acid (80:20:1; v/v/v) for the mobile phase for one hour, plates were sprayed with 50 percent sulfuric acid and left to dry overnight. The plates were then placed in a drying oven, approximately $110^{\circ} \mathrm{C}$ for $40 \mathrm{~min}$. Pictures

of the plates were then taken using the GelDocing system (Bio-Rad Gel Doc XR+ and ChemiDoc XRS+ Imaging Systems with Image Lab Software Version 6, California, United States) so that pixel density could be measured.

\subsection{Fatty Acid Analysis}

Fatty acid analysis was conducted on the initial powders and the lipids extracted from each using the various organic solvents. Initial powders and lipid extracts were methylated by adding $4 \mathrm{~mL}$ of $4 \% \mathrm{H} 2 \mathrm{SO} 4$ in anhydrous methanol with $\mathrm{C} 19$, an internal standard to quantify, then placed in a water bath at $90^{\circ} \mathrm{C}$ for $60 \mathrm{~min}$. Deionized distilled water, $3 \mathrm{~mL}$, was added to stop the reaction after incubation period. Chloroform, $8 \mathrm{~mL}$, was added to extract fatty acid methyl esters (FAME) and filtered through anhydrous Na2SO 4 . The collected layer was dried with nitrogen gas at $60^{\circ} \mathrm{C}$, diluted with isooctane, and stored at $-20^{\circ} \mathrm{C}$ until analyzed.

\subsection{Gas Chromatography-Flame Ionization Detection}

Fatty acid methyl esters were analyzed using a Varian CP-3800 Gas Chromatograph (Varian Analytical Instruments; Walnut Creek, California, U.S.A) equipped with a flame ionization detector (FID; Varian Inc., Walnut Creek, California, U.S.A). A silica capillary column (100 m length, $0.25 \mathrm{~mm}$ diameter) was used to separate FAMEs. A method of $140^{\circ} \mathrm{C}$ held for 5 min followed by a temperature ramp of $4^{\circ} \mathrm{C} / \mathrm{min}$ to $220^{\circ} \mathrm{C}$ held for $15 \mathrm{~min}$ was adopted; totaling to $85 \mathrm{~min}$ for each FAME separation. Temperatures were held at $270^{\circ} \mathrm{C}$ and $300^{\circ} \mathrm{C}$ for the injector and detector respectively. Identification of FAME in sample was based on retention times compared to FAME 37 standard. The Star GC workstation version 6 software was used to determine the peak area and relative amounts of each fatty acid in the samples. 


\subsection{Statistical Design}

The lipid extraction experiments were performed in triplicate $(n=3)$. For each triplicate, at least three measurements were taken, with exception of thin layer chromatography where duplicates were performed. One-way analysis of variance (ANOVA) was used to determine individual differences between treatments. Post-hoc analysis was conducted using Student's t-test with a significance level of $(\mathrm{P}<0.05)$. ANOVA statistical comparisons were conducted using SAS JMP version 13 (SAS Institute Inc., North Carolina, USA).

\section{Results and Discussion}

\subsection{Extraction Efficiency}

Table 1 shows that the lipid extraction efficiencies were greatest when CM was used as the organic solvent for cricket powder and both chloroform-methanol (CM) and hexane $(\mathrm{H})$ were used as the organic solvent for locust powder; however, when compared to the rest of the organic solvents, CM was the least effective of all at extracting lipid from silkworm powder $(\mathrm{P}<0.05$; Table 1). The lipid extraction efficiencies were best when $\mathrm{H}$ was used as the organic solvent for egg yolk powder and $\mathrm{CM}$ was the most effective when used as the organic solvent for krill powder $(\mathrm{P}<0.05$; Table 1).

CM $(2: 1 \mathrm{vol} / \mathrm{vol})$ is the nonpolar/polar solvent used in the Folch extraction and was used as the control in this study; therefore, it was not surprising that the CM was effective at lipid extraction. Chloroform is a non-polar chlorinated hydrocarbon that favors lipids with intermediate polarity such as triglycerides. When chloroform and methanol are mixed, nonpolar lipids separate into the chloroform phase while the methanol, which is polar, will extract the more polar membrane-associated lipids. A 2:1 ratio is typically used because if there was more methanol the solvent would become too polar thus, resulting in inadequate lipid extraction (Folch et al., 1957). Our results also show that $\mathrm{H}$ was as effective $(\mathrm{P}>0.05)$ as $\mathrm{CM}$ at extracting lipid from locust powders, likely because $\mathrm{H}$ is also a nonpolar hydrocarbon and commonly used for lipids with low

polarity (Baumler et al., 2010). Adult cricket and locust powders are comprised of similar amounts of triglycerides and phospholipids, whereas, pupae silkworm powder contains mainly triglycerides 
and a lower number of phospholipids. CM is an organic solvent combination with both nonpolar and polar properties which allows for the extraction of both nonpolar and polar lipids such as triglycerides and phospholipids, respectively, therefore it worked best for the cricket and locust powders.

On the other hand, MTBE was most effective at extracting lipid from silkworm powder $(\mathrm{P}<0.05$; Table 1). MTBE is part of the alkyl ethers chemical class which is more polar than hydrocarbons but less polar than alcohols, thus it will extract nonpolar and polar lipids. Pupae silkworm powder contains mainly triglycerides and a lower number of phospholipids and therefore, MTBE was most effective for lipid extraction for the silkworm powder (Matyash et al., 2008). MTBE also allows for faster, cleaner lipid recovery due to its low-density and forms an upper layer that simplifies collection. MTBE protocol delivers similar or better recoveries of species of most all major lipid classes compared with the Folch method using CM (Matyash et al., 2008).

Egg yolk lipid is comprised of more nonpolar lipids than polar lipids thus $\mathrm{H}$ was effective likely because it is a nonpolar hydrocarbon with properties for extracting lipids with low polarity. $\mathrm{CM}$ extracts both triglycerides and phospholipids but is most effective when high amounts of phospholipids are present; therefore, it was most effective for krill powder.

Differences in extraction efficiencies could be due to the ratio of sample/solvent. Gigliotti and colleagues (2011) found that ratios of 1:12 and 1:30 produced the greatest extraction efficiencies for krill meal when using acetone-ethanol as the organic solvent in the one-step extraction method, thus different ratios may result in better lipid extraction outcomes for the powders. Another reason for the differences in extraction efficiencies could be due to the length of the extraction time. Shorter extraction times are inadequate for extracting both triglycerides and phospholipids. Gigliotti and colleagues (2011) used an extraction time of $2 \mathrm{~h}$ for krill meal. However, Baümler and colleagues (2010), extracted lipid from 10g sunflower collets (pressed sunflower cake) using a one-step extraction method with $180 \mathrm{~mL}$ hexane as the organic solvent (1:18 sunflower collet:solvent); the length of extraction times ranged from 0 to $270 \mathrm{~min}$ at 40, 50, and $60^{\circ} \mathrm{C}$. Results showed that a 30 min extraction time at $60^{\circ} \mathrm{C}$ produced the highest extraction efficiency (98.1\%) along with triglyceride extraction (99.5\%) and phospholipid extraction (66.5\%) (Baümler, 2010). Triglyceride and phospholipid extraction occurred very quickly at the beginning of the extraction and plateaued at $30 \mathrm{~min}$ for all temperatures. Therefore, Baümler and colleagues 
(2010) recommended an extraction of 30 min due to producing a high extraction efficiency for sunflower collet in a short time frame. An extraction time of 25 min was used in this current study, it is possible that increasing the extraction time will improve extraction efficiency. Thus, when choosing solvents, polarity and ratio of the sample and solvent, and extraction times all impact how efficient the solvent will be in extracting the lipid.

\subsection{Lipid classes in extracted powder lipid}

The separation of lipids classes using thin layer chromatography and densitometry are shown in Table 2 and Figures 1 and 2. All organic solvents extracted lipid classes that were most like the initial silkworm powder ( $\mathrm{P}>0.05$; Table 2 ). $\mathrm{H}$ extracted lipid classes that were most like the initial cricket and silkworm powders $(\mathrm{P}>0.05$; Table 2$)$. Hexane is a hydrocarbon which is nonpolar and is a good solvent for lipids with low polarity, thus, triglycerides are very soluble, and phospholipids are moderately soluble in this solvent (Baumler et al., 2010). Cricket and silkworm are mostly composed of triglycerides which is likely why $\mathrm{H}$ extracted a lipid class most like the original powder. MTBE extracted lipid classes that were most like the initial powder for locust ( $P>0.05$; Table 2). MTBE is part of the alkyl ethers chemical class which is more polar than hydrocarbons, but less polar than alcohols, thus it extracts both nonpolar and polar lipids (Matyash et al., 2008). Locust is mostly composed of free fatty acids which are nonpolar which is likely why MTBE extracted a lipid class most like the original powder. Egg yolk lipid is mainly comprised of triglycerides which is why $\mathrm{H}$ and $\mathrm{HI}$ both extracted amounts of triglycerides most like to that is reported in the literature. Since egg yolk has a high amount of phospholipids CM extracted the most similar amount phospholipids that in reported in the literature. Krill lipid is low in triglycerides and has a high concentration of phospholipids therefore, $\mathrm{CM}$ extracted the most similar lipid classes reported in the literature. CM also extracted the greatest amount of phospholipid than the other organic solvents which is consistent with prior research on krill meal (Xie et al., 2017). Overall, MTBE was most effective at concentrating cholesterol for all powders $(\mathrm{P}<0.05$; Table 2). The polarities of the organic solvents will affect the type of lipid classes extracted, thus the "likes dissolves likes" statement holds true here (Cerkowniak et al., 2013).

\subsection{Fatty acid profile of extracted powder lipid}


The original insect powders have relatively high amounts of palmitic, stearic, oleic, linoleic, and linolenic fatty acids and none contained EPA or DHA (Brogan et al., 2018). The fatty acid profile of the separated cricket lipid was most similar to original powders when CM was used as the organic solvent; however, when MTBE and C were used as the organic solvents for silkworm and locust the fatty acid profile was most similar to the original, respectively $(\mathrm{P}>0.05$; Table 3). These insect powders have relatively the same fatty acid profile which is uncommon between different species, except for when they are eating the same host plant (Bukkens, 1996). All three insect powders came from the same company therefore, likely had been fed a similar diet.

The fatty acid profile of separated egg yolk lipid was most similar to the original powder when $\mathrm{H}$ was used as the organic solvent with the exception of C18:2n6c, C18:3n3, and DHA $(\mathrm{P}<0.05$; Table 3). Palmitic, stearic, and oleic fatty acids in egg yolk are associated with triglycerides thus the reason these fatty acids were best separated when $\mathrm{H}$ was used as the organic solvent. The other fatty acids are associated with phospholipids which is likely why the other organic solvents such as CM, HI, and MTBE extracted these fatty acids. It is unknown why a low amount of $\mathrm{C} 18: 3 \mathrm{n} 3$ was extracted from all organic solvents. The fatty acid profile for separated krill lipid was most similar to the original powder when $\mathrm{CM}$ was used $(\mathrm{P}<0.05$; Table 3$)$. In addition, HI produced fatty acids that associated are with phospholipids closest to the original powders because HI can extract a great amount of poplar lipids like CM. Overall fatty acid profile is also affected by the polarities of the solvents.

\section{Conclusions}

Results of this study showed that subjecting insect (cricket, locust, and silkworm), egg yolk, and krill powders to a one-step organic solvent extraction using CM, H, and MTBE resulted in the highest lipid extraction efficiency, respectively. This method shows that while H, HI, and MTBE have potential for locust, silkworm, and egg yolk lipid extraction to be used in foods, more studies need to be done to test purity and increase effectiveness and efficiencies of one step extraction methods; perhaps increasing the processing time. 


\section{References}

1. Anton, M. Chapter 1: Composition and Structure of Hen Egg Yolk. 2007. Retrieved from: https://link.springer.com/content/pdf/10.1007\%2F978-3- 540-37885-3_1.pdf.

2. Baülmer, E., Guillermo, H., \& Carelli, A.A. 2010. Solvent extraction: kinetic study of major and minor compounds. JAOCS. 12; 1489-1495.

3. Bridges, K.M., Gigliotti, J.C., Altman, S., \& Tou, J.C. 2010. Determination of digestibility, tissue deposition, and metabolism of omega-3 fatty acid content of krill protein concentrate in growing rats. Journal of Agricultural and Food Chemistry. 58(5); 2830-2837.

4. Brogan, E., Jaczynski, J., \& Park, Y.L. 2017. Biochemical properties of insect flours. From Poster Presentation

5. Bukkens, S. 1996. The nutritional value of edible insects. National Institute of Nutrition 36 (2-4); 287-319.

6. Cerkowniak, M., Puckowski, A., Stepnowski, P., \& Golebiowski, M. 2013. The use of chromatographic techniques for the separation and the identification of insect lipids. Journal of Chromatography B. 937; 67-78.

7. DeFoliart, G.R. 1991. Insect fatty acids: Similar to those of poultry and fish in their degree of unsaturation, but higher in polyunsaturates. Food Insects Newsletter. 4; 1-4.

8. Folch, J.,\& Lees, M., Sloane, S. A simple method for isolation and purification of total lipids from animal tissues. 1957. Journal of Biological Chemistry. 226; 497-509.

9. Food and Drug Administration. Code of Federal Regulations Title 21. U.S Department of Health and Human Services.

10. Gigliotti, J., Davenport, M.P., Beamer, S.K., Tou, J.C., \& Jaczynsiki, J. 2011. Extraction and characterization of lipids from Antarctic krill (Euphausia superba). Food Chemistry. $125 ; 1028-1036$.

11. JMP, Version 13 SAS Institute Inc., Cary, NC, 1989-2017.

12. Matyash, V., Liebisch, G., Kurzchalia, T.V., Shevchenko, A., \& Schwudke, D. 2008. Lipid extraction by methyl-tert-butyl ether for high-throughput lipidomics. J Lipid Res. 49(5); 11371146.

13. Methyl Tertiary Butyl Ether (MTBE). 2016. EPA's Office of Transportation and Air Quality (OTAQ). Retrieved from: https://archive.epa.gov/mtbe/web/html/water.html. 
14. Tzompa-Sosa, D., Yi, L., van Valenberg, H.J.F., van Boekel, M.A.J.S., and Lakemond, C.M.M. 2014. Insect lipid profile: aqueous versus organic solvent-based extraction methods. Food Research International. 62; 1087-1094.

15. Xie, D., Jin, J., Sun, J., Liang, Li., Wang, X., Zhang, W., Wang, X., \& Jin, Q. 2017. Comparison of solvents for extraction of krill oil from krill meal: Lipid yield, phospholipids content, fatty acids composition and minor components. Food Chemistry. $233 ; 434-441$.

16. Yi, L., Lakemond, C.M.M., Sagis, L.M.C., Eisner-Schadler, V., van Huis, A., \& van Boekel, A.J.S. 2013. Extraction and characterization of protein fractions from five insect species. Food Chemistry. 141 (4); 3341-3348. 


\section{Tables and Figures}

Table 1: Lipid extraction efficiencies $(\mathrm{g} / 100 \mathrm{~g})$ following one-step organic solvent extraction with various organic solvents

\begin{tabular}{lllllc}
\hline Sample & Hexane & Chloroform & $\begin{array}{c}\text { Chloroform- } \\
\text { Methanol }^{-}\end{array}$ & $\begin{array}{c}\text { Methyl-Tert- } \\
\text { Butyl-Ether }\end{array}$ & $\begin{array}{c}\text { Hexane- } \\
\text { Isopropanol }\end{array}$ \\
\hline Cricket & $42.69 \pm 5.96^{\mathrm{B}, \mathrm{b}}$ & $37.69 \pm 7.91^{\mathrm{A}, \mathrm{b}}$ & $69.32 \pm 2.61^{\mathrm{B}, \mathrm{a}}$ & $27.65 \pm 3.86^{\mathrm{A}, \mathrm{B}, \mathrm{b}}$ & $23.65 \pm 5.13^{\mathrm{B}, \mathrm{C}, \mathrm{b}}$ \\
Locust & $75.14 \pm 0.10^{\mathrm{A}, \mathrm{a}}$ & $38.96 \pm 2.29^{\mathrm{A}, \mathrm{b}}$ & $93.03 \pm 12.09^{\mathrm{A}, \mathrm{a}}$ & $66.18 \pm 12.40^{\mathrm{A}, \mathrm{b}}$ & $18.53 \pm 4.34^{\mathrm{B}, \mathrm{C}, \mathrm{c}}$ \\
Silkworm & $51.29 \pm 6.77^{\mathrm{A}, \mathrm{B}, \mathrm{b}}$ & $42.06 \pm 5.44^{\mathrm{A}, \mathrm{b}}$ & $34.96 \pm 0.03^{\mathrm{C}, \mathrm{c}}$ & $59.65 \pm 2.48^{\mathrm{A}, \mathrm{a}}$ & $54.10 \pm 6.14^{\mathrm{A}, \mathrm{a}}$ \\
Egg Yolk & $34.44 \pm 0.16^{\mathrm{B}, \mathrm{C}, \mathrm{a}, \mathrm{b}}$ & $30.38 \pm 1.44^{\mathrm{A}, \mathrm{a}}$ & $30.71 \pm 1.64^{\mathrm{C}, \mathrm{b}}$ & $24.01 \pm 4.00^{\mathrm{A}, \mathrm{B}, \mathrm{b}}$ & $27.03 \pm 0.12^{\mathrm{B}, \mathrm{c}}$ \\
Krill & $10.79 \pm 3.96^{\mathrm{C}, \mathrm{b}}$ & $4.20 \pm 0.08^{\mathrm{B}, \mathrm{b}}$ & $19.15 \pm 1.93^{\mathrm{C}, \mathrm{a}}$ & $8.09 \pm 0.74^{\mathrm{B}, \mathrm{b}}$ & $4.77 \pm 2.27^{\mathrm{C}, \mathrm{b}}$ \\
\hline
\end{tabular}

$\overline{\mathrm{A}, \mathrm{B}, \mathrm{C}}$ Different letters indicate significant differences (Student's $t$ test, $\mathrm{P}<0.05$ ) between mean values $( \pm \mathrm{SD}, \mathrm{n}=3)$ within the same column.

a,b,c Different letters indicate significant differences (Student's t test, $\mathrm{P}<0.05$ ) between mean values $( \pm \mathrm{SD}, \mathrm{n}=3)$ within the same row. 
Table 2: Thin layer chromatography (TLC) densitometry analysis of lipid classes (\%) extracted using a one-step organic solvent extraction with various organic solvents.

\begin{tabular}{|c|c|c|c|c|c|c|c|}
\hline Lipid Class & $\begin{array}{c}\text { Powder } \\
\text { Type }\end{array}$ & Initial Powder* & Hexane & Chloroform & $\begin{array}{l}\text { Chloroform- } \\
\text { Methanol }\end{array}$ & $\begin{array}{l}\text { Methyl-Tert- } \\
\text { Butyl-Ether }\end{array}$ & $\begin{array}{l}\text { Hexane- } \\
\text { Isopropanol }\end{array}$ \\
\hline \multirow[t]{5}{*}{ Triglycerides } & Cricket & $37.95 \pm 3.32^{\mathrm{C}, \mathrm{a}}$ & $46.20 \pm 7.44^{\mathrm{B}, \mathrm{a}}$ & $41.88 \pm 0.66^{\mathrm{C}, \mathrm{a}}$ & $32.62 \pm 6.99^{\mathrm{C}, \mathrm{a}}$ & $35.58 \pm 6.59^{\mathrm{C}, \mathrm{a}}$ & $36.46 \pm 1.51^{\mathrm{C}, \mathrm{a}}$ \\
\hline & Locust & $24.67 \pm 4.91^{\mathrm{D}, \mathrm{b}}$ & $46.99 \pm 4.95^{\mathrm{B}, \mathrm{a}}$ & $42.34 \pm 2.14^{\mathrm{C}, \mathrm{a}}$ & $42.55 \pm 3.49^{\mathrm{C}, \mathrm{a}}$ & $27.05 \pm 2.45^{\mathrm{C}, \mathrm{D}, \mathrm{b}}$ & $18.90 \pm 1.77^{\mathrm{D}, \mathrm{b}}$ \\
\hline & Silkworm & $74.24 \pm 3.11^{\mathrm{A}, \mathrm{a}}$ & $74.60 \pm 6.41^{\mathrm{A}, \mathrm{a}}$ & $80.20 \pm 1.89^{\mathrm{A}, \mathrm{a}}$ & $72.00 \pm 0.40^{\mathrm{A}, \mathrm{a}}$ & $77.84 \pm 1.89^{\mathrm{A}, \mathrm{a}}$ & $81.32 \pm 0.99^{\mathrm{A}, \mathrm{a}}$ \\
\hline & Egg Yolk & $62.00 \pm 0.00^{\mathrm{B}, \mathrm{b}, \mathrm{c}}$ & $62.77 \pm 1.70^{\mathrm{B}, \mathrm{b}}$ & $57.09 \pm 1.68^{\mathrm{B}, \mathrm{c}}$ & $53.83 \pm 1.76^{\mathrm{B}, \mathrm{d}}$ & $56.03 \pm 1.55^{\mathrm{B}, \mathrm{d}}$ & $63.86 \pm 0.88^{\mathrm{B}, \mathrm{d}}$ \\
\hline & Krill & $26.00 \pm 7.40^{\mathrm{D}, \mathrm{a}, \mathrm{b}}$ & $24.30 \pm 3.77^{\mathrm{C}, \mathrm{a}}$ & $18.15 \pm 1.55^{\mathrm{D}, \mathrm{b}}$ & $11.15 \pm 1.25^{\mathrm{D}, \mathrm{c}}$ & $19.53 \pm 4.94^{\mathrm{D}, \mathrm{a}, \mathrm{b}}$ & $14.92 \pm 1.38^{\mathrm{D}, \mathrm{c}}$ \\
\hline \multirow[t]{5}{*}{ Phospholipid } & Cricket & $25.48 \pm 1.88^{\mathrm{A}, \mathrm{b}, \mathrm{c}}$ & $21.11 \pm 0.01^{\mathrm{B}, \mathrm{c}}$ & $30.50 \pm 0.31^{\mathrm{A}, \mathrm{a}, \mathrm{b}}$ & $25.02 \pm 1.66^{\mathrm{B}, \mathrm{b}, \mathrm{c}}$ & $35.38 \pm 3.33^{\mathrm{A}, \mathrm{a}}$ & $26.98 \pm 1.53^{\mathrm{A}, \mathrm{B}, \mathrm{a}, \mathrm{b}, \mathrm{c}}$ \\
\hline & Locust & $24.58 \pm 5.18^{\mathrm{A}, \mathrm{a}}$ & $14.50 \pm 2.76^{\mathrm{C}, \mathrm{b}}$ & $29.96 \pm 5.18^{\mathrm{A}, \mathrm{a}, \mathrm{b}}$ & $25.73 \pm 2.95^{\mathrm{B}, \mathrm{a}}$ & $20.11 \pm 0.89^{\mathrm{B}, \mathrm{a}, \mathrm{b}}$ & $30.59 \pm 3.93^{\mathrm{A}, \mathrm{a}}$ \\
\hline & Silkworm & $6.08 \pm 1.37^{\mathrm{B}, \mathrm{a}, \mathrm{b}}$ & $6.41 \pm 1.10^{\mathrm{D}, \mathrm{a}, \mathrm{b}}$ & $6.96 \pm 0.90^{\mathrm{B}, \mathrm{a}, \mathrm{b}}$ & $12.77 \pm 4.15^{\mathrm{C}, \mathrm{a}}$ & $4.82 \pm 1.15^{\mathrm{C}, \mathrm{b}}$ & $6.82 \pm 0.24^{\mathrm{C}, \mathrm{a}, \mathrm{b}}$ \\
\hline & Egg Yolk & $33.00 \pm 0.00^{\mathrm{B}, \mathrm{a}}$ & $11.07 \pm 1.91^{\mathrm{C}, \mathrm{D}, \mathrm{d}}$ & $16.66 \pm 1.84^{\mathrm{B}, \mathrm{c}, \mathrm{d}}$ & $25.53 \pm 1.52^{\text {B.b }}$ & $15.71 \pm 1.45^{\mathrm{B}, \mathrm{C}, \mathrm{c}}$ & $16.32 \pm 0.23^{\mathrm{B}, \mathrm{C}, \mathrm{c}}$ \\
\hline & Krill & $66.60 \pm 6.30^{\mathrm{A}, \mathrm{a}}$ & $31.58 \pm 1.01^{\mathrm{A}, \mathrm{c}}$ & $36.46 \pm 5.92^{\mathrm{A}, \mathrm{c}}$ & $45.29 \pm 5.42^{\mathrm{A}, \mathrm{b}}$ & $32.98 \pm 8.93^{\mathrm{A}, \mathrm{c}}$ & $33.59 \pm 5.76^{\mathrm{A}, \mathrm{c}}$ \\
\hline \multirow[t]{5}{*}{ Cholesterol } & Cricket & $9.53 \pm 2.59^{\mathrm{A}, \mathrm{b}}$ & $13.18 \pm 1.16^{\mathrm{C}, \mathrm{a}, \mathrm{b}}$ & $16.06 \pm 3.75^{\mathrm{B}, \mathrm{a}, \mathrm{b}}$ & $19.08 \pm 5.36^{\mathrm{A}, \mathrm{a}}$ & $18.03 \pm 3.70^{\mathrm{A}, \mathrm{B}, \mathrm{a}}$ & $12.92 \pm 2.45^{\mathrm{B}, \mathrm{a}, \mathrm{b}}$ \\
\hline & Locust & $8.78 \pm 2.22^{\mathrm{A}, \mathrm{c}}$ & $14.54 \pm 0.09^{\mathrm{C}, \mathrm{a}, \mathrm{b}}$ & $8.33 \pm 0.14^{\mathrm{C}, \mathrm{b}, \mathrm{c}}$ & $10.93 \pm 0.22^{\mathrm{B}, \mathrm{b}, \mathrm{c}}$ & $18.92 \pm 1.68^{\mathrm{A}, \mathrm{B}, \mathrm{a}}$ & $17.87 \pm 3.35^{\mathrm{A}, \mathrm{B}, \mathrm{a}}$ \\
\hline & Silkworm & $6.70 \pm 1.09^{\mathrm{A}, \mathrm{a}, \mathrm{b}}$ & $6.62 \pm 2.36^{\mathrm{D}, \mathrm{a}, \mathrm{b}}$ & $4.24 \pm 0.69^{\mathrm{C}, \mathrm{b}}$ & $6.51 \pm 0.02^{\mathrm{B}, \mathrm{a}, \mathrm{b}}$ & $7.85 \pm 1.21^{\mathrm{B}, \mathrm{a}}$ & $4.47 \pm 1.71^{\mathrm{C}, \mathrm{a}, \mathrm{b}}$ \\
\hline & Egg Yolk & $5.00 \pm 0.00^{\mathrm{B}, \mathrm{d}}$ & $26.15 \pm 0.25^{\mathrm{B}, \mathrm{a}}$ & $26.24 \pm 0.16^{\mathrm{A}, \mathrm{a}}$ & $20.62 \pm 0.24^{\mathrm{A}, \mathrm{b}}$ & $28.25 \pm 2.97^{\mathrm{A}, \mathrm{a}}$ & $19.80 \pm 0.65^{\mathrm{A}, \mathrm{B}, \mathrm{b}}$ \\
\hline & Krill & $6.10 \pm 0.90^{\mathrm{A}, \mathrm{d}}$ & $37.45 \pm 2.41^{\mathrm{A}, \mathrm{a}}$ & $19.68 \pm 2.41^{\mathrm{B}, \mathrm{c}}$ & $17.75 \pm 0.99^{\mathrm{A}, \mathrm{c}}$ & $25.33 \pm 6.42^{\mathrm{A}, \mathrm{b}}$ & $25.86 \pm 4.45^{\mathrm{A}, \mathrm{b}}$ \\
\hline Free Fatty & Cricket & $27.03 \pm 1.53^{\mathrm{B}, \mathrm{a}}$ & $19.46 \pm 0.58^{\mathrm{A}, \mathrm{B}, \mathrm{a}, \mathrm{b}}$ & $12.05 \pm 1.05^{\mathrm{C}, \mathrm{b}}$ & $17.22 \pm 4.69^{\mathrm{B}, \mathrm{a}, \mathrm{b}}$ & $9.40 \pm 2.23^{\mathrm{C}, \mathrm{b}}$ & $12.71 \pm 5.35^{\mathrm{C}, \mathrm{b}}$ \\
\hline \multirow[t]{4}{*}{ Acids } & Locust & $41.34 \pm 5.04^{\mathrm{A}, \mathrm{a}}$ & $23.95 \pm 0.44^{\mathrm{A}, \mathrm{c}, \mathrm{d}}$ & $19.35 \pm 2.89^{\mathrm{B}, \mathrm{d}}$ & $20.77 \pm 3.28^{\mathrm{A}, \mathrm{B}, \mathrm{d}}$ & $33.91 \pm 0.93^{\mathrm{A}, \mathrm{a}, \mathrm{b}}$ & $32.61 \pm 0.28^{\mathrm{A}, \mathrm{b}, \mathrm{c}}$ \\
\hline & Silkworm & $6.94 \pm 3.20^{\mathrm{C}, \mathrm{a}}$ & $12.35 \pm 5.66^{\mathrm{A}, \mathrm{B}, \mathrm{C}, \mathrm{a}}$ & $8.58 \pm 1.6^{\mathrm{C}, \mathrm{a}}$ & $8.70 \pm 1.42^{\mathrm{C}, \mathrm{a}}$ & $9.47 \pm 1.46^{\mathrm{C}, \mathrm{a}}$ & $7.38 \pm 1.34^{\mathrm{C}, \mathrm{a}}$ \\
\hline & Egg Yolk & $0.00 \pm 0.00^{\mathrm{B}, \mathrm{a}}$ & $0.00 \pm 0.00^{\mathrm{C}, \mathrm{a}}$ & $0.00 \pm 0.00^{\mathrm{D}, \mathrm{a}}$ & $0.00 \pm 0.00^{\mathrm{D}, \mathrm{a}}$ & $0.00 \pm 0.00^{\mathrm{D}, \mathrm{a}}$ & $0.00 \pm 0.00^{\mathrm{D}, \mathrm{a}}$ \\
\hline & Krill & $1.30 \pm 0.30^{\mathrm{A}, \mathrm{b}}$ & $6.65 \pm 1.92^{\mathrm{B}, \mathrm{C}, \mathrm{b}}$ & $25.69 \pm 2.86^{\mathrm{A}, \mathrm{a}}$ & $25.78 \pm 5.04^{\mathrm{A}, \mathrm{a}}$ & $22.14 \pm 2.94^{\mathrm{B}, \mathrm{a}}$ & $25.62 \pm 4.65^{\mathrm{B}, \mathrm{a}}$ \\
\hline
\end{tabular}

$\overline{\mathrm{A}, \mathrm{B}, \mathrm{C}}$ Different letters indicate significant differences (Student's t test, $\mathrm{P}<0.05)$ between mean values $( \pm \mathrm{SD}$, $\mathrm{n}=3)$ of lipid classes between lipid source within the column.

a,b,c Different letters indicate significant differences (Student's t test, $\mathrm{P}<0.05)$ between mean values $( \pm \mathrm{SD}$, $\mathrm{n}=3$ ) within the same row.

*Initial Powder-Brogan et al., 2018; Initial Egg Yolk Powder- Anton, 2007; Initial Krill Powder- Xie et al., 2017 
Table 3: Fatty acid composition (\%) of insect powders (cricket, locust, and silkworm) and extracted lipid following a one-step organic solvent extraction with various organic solvents.

\begin{tabular}{|c|c|c|c|c|c|c|c|}
\hline $\begin{array}{l}\text { Fatty } \\
\text { Acid }\end{array}$ & $\begin{array}{c}\text { Powder } \\
\text { Type }\end{array}$ & Initial Powder* & Hexane & Chloroform & $\begin{array}{c}\text { Chloroform- } \\
\text { Methanol }\end{array}$ & $\begin{array}{l}\text { Methyl-Tert- } \\
\text { Butyl-Ether }\end{array}$ & $\begin{array}{c}\text { Hexane- } \\
\text { Isopropanol }\end{array}$ \\
\hline \multirow[t]{5}{*}{ C16:0 } & Cricket & $23.10 \pm 0.44^{\mathrm{A}, \mathrm{c}}$ & $24.87 \pm 0.68^{\mathrm{B}, \mathrm{C}, \mathrm{a}, \mathrm{b}}$ & $24.24 \pm 0.76^{\mathrm{Cb}, \mathrm{c}}$ & $23.20 \pm 0.93^{\mathrm{A}, \mathrm{B}, \mathrm{c}}$ & $24.23 \pm 0.51^{\mathrm{B}, \mathrm{b}, \mathrm{c}}$ & $25.98 \pm 0.80^{\mathrm{B}, \mathrm{a}}$ \\
\hline & Locust & $22.32 \pm 0.11^{\mathrm{B}, \mathrm{c}}$ & $55.01 \pm 4.47^{\mathrm{A}, \mathrm{a}}$ & $24.65 \pm 0.73^{\mathrm{C}, \mathrm{c}}$ & $51.06 \pm 0.37^{\mathrm{A}, \mathrm{b}}$ & $41.83 \pm 5.15^{\mathrm{A}, \mathrm{a}}$ & $32.30 \pm 5.38^{\mathrm{A}, \mathrm{B}, \mathrm{b}}$ \\
\hline & Silkworm & $20.62 \pm 0.08^{\mathrm{D}, \mathrm{c}}$ & $20.47 \pm 1.04^{\mathrm{C}, \mathrm{c}}$ & $19.79 \pm 0.85^{\mathrm{C}, \mathrm{c}}$ & $26.89 \pm 1.04^{\mathrm{B}, \mathrm{b}}$ & $20.33 \pm 1.04^{\mathrm{B}, \mathrm{c}}$ & $34.47 \pm 1.04^{\mathrm{A}, \mathrm{a}}$ \\
\hline & Egg Yolk & $21.11 \pm 2.50^{\mathrm{C}, \mathrm{c}}$ & $39.34 \pm 0.15^{\text {A,В.b }}$ & $57.52 \pm 0.29^{\mathrm{A}, \mathrm{a}}$ & $40.96 \pm 1.47^{\mathrm{A}, \mathrm{B}, \mathrm{b}}$ & $39.40 \pm 1.54^{\mathrm{A}, \mathrm{b}}$ & $40.70 \pm 0.08^{\mathrm{A}, \mathrm{B}, \mathrm{b}}$ \\
\hline & Krill & $21.38 \pm 0.34^{\mathrm{C}, \mathrm{c}}$ & $51.37 \pm 1.52^{\mathrm{A}, \mathrm{a}}$ & $44.39 \pm 3.05^{\mathrm{B}, \mathrm{b}}$ & $36.65 \pm 10.51^{\mathrm{A}, \mathrm{B}, \mathrm{a}, \mathrm{b}}$ & $42.85 \pm 4.74^{\mathrm{A}, \mathrm{b}}$ & $45.44 \pm 6.14^{\mathrm{A}, \mathrm{B}, \mathrm{b}}$ \\
\hline \multirow[t]{5}{*}{ C18:0 } & Cricket & $9.96 \pm 0.17^{\mathrm{B}, \mathrm{a}}$ & $8.25 \pm 0.28^{\mathrm{A}, \mathrm{b}}$ & $7.78 \pm 0.28^{\mathrm{B}, \mathrm{b}}$ & $8.35 \pm 0.55^{\mathrm{B}, \mathrm{C}, \mathrm{b}}$ & $8.00 \pm 0.45^{\mathrm{B}, \mathrm{b}}$ & $8.05 \pm 0.13^{\mathrm{A}, \mathrm{B}, \mathrm{b}}$ \\
\hline & Locust & $10.26 \pm 0.10^{\mathrm{A}, \mathrm{c}}$ & $5.34 \pm 0.31^{\mathrm{A}, \mathrm{B}, \mathrm{d}}$ & $22.46 \pm 1.54^{\mathrm{A}, \mathrm{a}}$ & $19.17 \pm 0.21^{\mathrm{A}, \mathrm{b}}$ & $13.97 \pm 1.96^{\mathrm{A}, \mathrm{b}}$ & $14.74 \pm 2.35^{\mathrm{A}, \mathrm{c}}$ \\
\hline & Silkworm & $6.55 \pm 0.05^{\mathrm{D}, \mathrm{c}}$ & $7.13 \pm 1.46^{\mathrm{A}, \mathrm{B}, \mathrm{b}, \mathrm{c}}$ & $6.46 \pm 3.70^{\mathrm{B}, \mathrm{C}, \mathrm{c}}$ & $8.95 \pm 0.52^{\mathrm{B}, \mathrm{a}, \mathrm{b}}$ & $7.66 \pm 2.01^{\mathrm{B}, \mathrm{C}, \mathrm{b}, \mathrm{c}}$ & $10.45 \pm 1.05^{\mathrm{B}, \mathrm{C}, \mathrm{a}}$ \\
\hline & Egg Yolk & $7.44 \pm 1.24^{\mathrm{C}, \mathrm{a}}$ & $0.11 \pm 0.00^{\mathrm{B}, \mathrm{c}}$ & $0.14 \pm 0.00^{\mathrm{D}, \mathrm{b}}$ & $0.10 \pm 0.00^{\mathrm{D}, \mathrm{c}}$ & $0.12 \pm 0.00^{\mathrm{C}, \mathrm{b}, \mathrm{c}}$ & $0.10 \pm 0.00^{\mathrm{C}, \mathrm{c}}$ \\
\hline & Krill & $1.06 \pm 0.08^{\mathrm{E}, \mathrm{c}}$ & $2.67 \pm 0.46^{\mathrm{A}, \mathrm{B}, \mathrm{a}}$ & $2.98 \pm 1.37^{\mathrm{C}, \mathrm{D}, \mathrm{b}, \mathrm{c}}$ & $2.58 \pm 0.19^{\mathrm{C}, \mathrm{D}, \mathrm{c}}$ & $1.96 \pm 0.91^{\mathrm{C}, \mathrm{c}}$ & $2.98 \pm 0.39^{\mathrm{B}, \mathrm{C}, \mathrm{b}}$ \\
\hline \multirow[t]{5}{*}{ C18:1n9c } & Cricket & $22.02 \pm 0.35^{\mathrm{D}, \mathrm{c}}$ & $28.34 \pm 1.14^{\mathrm{B}, \mathrm{a}}$ & $27.24 \pm 1.10^{\mathrm{A}, \mathrm{a}}$ & $25.32 \pm 0.78^{\mathrm{A}, \mathrm{B}, \mathrm{b}}$ & $27.61 \pm 0.52^{\mathrm{A}, \mathrm{B}, \mathrm{a}}$ & $27.57 \pm 0.41^{\mathrm{A}, \mathrm{a}}$ \\
\hline & Locust & $22.35 \pm 0.14^{\mathrm{C}, \mathrm{b}}$ & $0.92 \pm 0.97^{\mathrm{C}, \mathrm{d}}$ & $18.08 \pm 3.52^{\mathrm{A}, \mathrm{c}}$ & $0.79 \pm 0.63^{\mathrm{C}, \mathrm{d}}$ & $14.64 \pm 0.04^{\mathrm{B}, \mathrm{d}}$ & $24.75 \pm 0.00^{\mathrm{A}, \mathrm{a}}$ \\
\hline & Silkworm & $30.60 \pm 0.06^{\mathrm{B}, \mathrm{b}}$ & $31.82 \pm 3.60^{\mathrm{A}, \mathrm{b}}$ & $28.79 \pm 0.98^{\mathrm{A}, \mathrm{b}}$ & $11.80 \pm 0.08^{\mathrm{B}, \mathrm{C}, \mathrm{c}}$ & $29.04 \pm 1.77^{\mathrm{A}, \mathrm{B}, \mathrm{b}}$ & $50.33 \pm 2.79^{\mathrm{A}, \mathrm{a}}$ \\
\hline & Egg Yolk & $33.91 \pm 1.78^{\mathrm{A}, \mathrm{c}}$ & $42.82 \pm 0.51^{\mathrm{A}, \mathrm{a}}$ & $13.89 \pm 0.40^{\mathrm{A}, \mathrm{d}}$ & $41.06 \pm 1.66^{\mathrm{A}, \mathrm{b}}$ & $43.54 \pm 0.55^{\mathrm{A}, \mathrm{a}}$ & $39.73 \pm 0.24^{\mathrm{A}, \mathrm{b}}$ \\
\hline & Krill & $10.16 \pm 0.36^{\mathrm{E}, \mathrm{b}}$ & $13.80 \pm 4.93^{\mathrm{C}, \mathrm{b}}$ & $14.30 \pm 0.93^{\mathrm{A}, \mathrm{a}}$ & $8.41 \pm 2.07^{\mathrm{B}, \mathrm{C}, \mathrm{b}, \mathrm{c}}$ & $20.26 \pm 2.43^{\mathrm{B}, \mathrm{a}}$ & $17.69 \pm 2.65^{\mathrm{A}, \mathrm{a}}$ \\
\hline \multirow[t]{3}{*}{ C18:2n6c } & Cricket & $35.19 \pm 0.26^{\mathrm{A}, \mathrm{d}}$ & $37.83 \pm 2.03^{\mathrm{A}, \mathrm{b}, \mathrm{c}}$ & $40.00 \pm 1.63^{\mathrm{A}, \mathrm{a}, \mathrm{b}}$ & $42.39 \pm 1.19^{\mathrm{A}, \mathrm{a}}$ & $39.35 \pm 1.01^{\mathrm{A}, \mathrm{b}, \mathrm{c}}$ & $37.53 \pm 1.33^{\mathrm{A}, \mathrm{c}, \mathrm{d}}$ \\
\hline & Locust & $23.02 \pm 0.57^{\mathrm{C}, \mathrm{a}}$ & $11.95 \pm 2.83^{\mathrm{B}, \mathrm{b}}$ & $17.68 \pm 1.51^{\mathrm{B}, \mathrm{b}}$ & $12.01 \pm 0.13^{\mathrm{B}, \mathrm{b}}$ & $8.51 \pm 4.99^{\mathrm{C}, \mathrm{b}, \mathrm{c}}$ & $7.91 \pm 2.64^{\mathrm{B}, \mathrm{C}, \mathrm{c}}$ \\
\hline & Silkworm & $5.74 \pm 0.03^{\mathrm{D}, \mathrm{a}}$ & $6.88 \pm 0.84^{\mathrm{B}, \mathrm{C}, \mathrm{a}}$ & $6.49 \pm 0.33^{\mathrm{D}, \mathrm{a}}$ & $8.48 \pm 0.52^{\mathrm{B}, \mathrm{a}}$ & $7.18 \pm 1.31^{\mathrm{C}, \mathrm{a}}$ & $4.65 \pm 6.55^{\mathrm{B,C,a}}$ \\
\hline
\end{tabular}




\begin{tabular}{|c|c|c|c|c|c|c|c|}
\hline & Egg Yolk & $28.45 \pm 3.67^{\mathrm{B}, \mathrm{a}}$ & $0.01 \pm 0.00^{\mathrm{C}, \mathrm{c}}$ & $0.68 \pm 0.32^{\mathrm{E}, \mathrm{b}}$ & $3.03 \pm 0.00^{\mathrm{B}, \mathrm{c}}$ & $2.99 \pm 0.00^{\mathrm{C}, \mathrm{c}}$ & $0.01 \pm 0.00^{\mathrm{C}, \mathrm{c}}$ \\
\hline & Krill & $1.92 \pm 0.01^{\mathrm{E}, \mathrm{c}}$ & $13.80 \pm 4.93^{\mathrm{B}, \mathrm{b}}$ & $14.30 \pm 0.93^{\mathrm{C}, \mathrm{a}}$ & $8.41 \pm 2.07^{\mathrm{B}, \mathrm{b}, \mathrm{c}}$ & $20.26 \pm 2.43^{\mathrm{B}, \mathrm{a}}$ & $17.69 \pm 2.65^{\mathrm{B}, \mathrm{a}}$ \\
\hline \multirow[t]{5}{*}{ C18:3n3 } & Cricket & $0.61 \pm 0.01^{\mathrm{C}, \mathrm{D}, \mathrm{d}}$ & $0.68 \pm 0.05^{\mathrm{C}, \mathrm{c}, \mathrm{d}}$ & $0.71 \pm 0.02^{\mathrm{C}, \mathrm{b}, \mathrm{c}}$ & $0.71 \pm 0.03^{\mathrm{C}, \mathrm{b}, \mathrm{c}}$ & $0.78 \pm 0.01^{\mathrm{C}, \mathrm{a}, \mathrm{b}}$ & $0.85 \pm 0.09^{\mathrm{B}, \mathrm{a}}$ \\
\hline & Locust & $13.69 \pm 0.69^{\mathrm{B}, \mathrm{b}}$ & $26.76 \pm 6.12^{\mathrm{B}, \mathrm{a}}$ & $17.11 \pm 0.66^{\mathrm{B}, \mathrm{b}}$ & $16.93 \pm 1.06^{\mathrm{B}, \mathrm{a}}$ & $21.03 \pm 7.81^{\mathrm{B}, \mathrm{a}}$ & $20.27 \pm 5.78^{\mathrm{A}, \mathrm{a}}$ \\
\hline & Silkworm & $33.34 \pm 0.08^{\mathrm{A}, \mathrm{c}}$ & $42.83 \pm 1.06^{\mathrm{A}, \mathrm{b}}$ & $40.57 \pm 2.83^{\mathrm{A}, \mathrm{b}}$ & $53.10 \pm 3.37^{\mathrm{A}, \mathrm{a}}$ & $41.05 \pm 1.25^{\mathrm{A}, \mathrm{b}}$ & $0.10 \pm 0.06^{\mathrm{B}, \mathrm{d}}$ \\
\hline & Egg Yolk & $0.95 \pm 0.96^{\mathrm{C}, \mathrm{a}}$ & $0.13 \pm 0.00^{\mathrm{C}, \mathrm{c}}$ & $0.18 \pm 0.02^{\mathrm{C}, \mathrm{c}}$ & $0.05 \pm 0.00^{\mathrm{C}, \mathrm{d}}$ & $0.33 \pm 0.00^{\mathrm{C}, \mathrm{b}}$ & $0.34 \pm 0.00^{\mathrm{B}, \mathrm{b}}$ \\
\hline & Krill & $0.24 \pm 0.04^{\mathrm{D}, \mathrm{c}}$ & $1.05 \pm 0.37^{\mathrm{C}, \mathrm{a}}$ & $0.42 \pm 0.39^{\mathrm{C}, \mathrm{a}}$ & $1.99 \pm 0.11^{\mathrm{C}, \mathrm{b}, \mathrm{c}}$ & $1.01 \pm 0.13^{\mathrm{C}, \mathrm{a}, \mathrm{b}}$ & $0.46 \pm 0.40^{\mathrm{B}, \mathrm{c}}$ \\
\hline \multirow[t]{2}{*}{ EPA } & Egg Yolk & $0.09 \pm 0.07^{\mathrm{B}, \mathrm{a}}$ & $0.00 \pm 0.00^{\mathrm{B}, \mathrm{c}}$ & $0.00 \pm 0.00^{\mathrm{B}, \mathrm{c}}$ & $0.00 \pm 0.00^{\mathrm{B}, \mathrm{c}}$ & $0.00 \pm 0.00^{\mathrm{B}, \mathrm{c}}$ & $0.00 \pm 0.00^{\mathrm{B}, \mathrm{c}}$ \\
\hline & Krill & $17.81 \pm 0.42^{\mathrm{A}, \mathrm{a}}$ & $1.63 \pm 0.65^{\mathrm{A}, \mathrm{c}}$ & $3.47 \pm 0.68^{\mathrm{A}, \mathrm{b}}$ & $4.90 \pm 1.19^{\mathrm{A}, \mathrm{b}}$ & $3.08 \pm 1.04^{\mathrm{A}, \mathrm{b}}$ & $4.37 \pm 0.44^{\mathrm{A}, \mathrm{b}}$ \\
\hline \multirow[t]{2}{*}{ DHA } & Egg Yolk & $0.31 \pm 0.28^{\mathrm{B}, \mathrm{c}}$ & $0.22 \pm 0.04^{\mathrm{B}, \mathrm{d}}$ & $0.52 \pm 0.13^{\mathrm{B}, \mathrm{a}}$ & $0.38 \pm 0.02^{\mathrm{B}, \mathrm{b}}$ & $0.28 \pm 0.02^{\mathrm{B}, \mathrm{d}}$ & $0.37 \pm 0.00^{\mathrm{B}, \mathrm{b}}$ \\
\hline & Krill & $12.32 \pm 0.10^{\mathrm{A}, \mathrm{a}}$ & $1.62 \pm 1.65^{\mathrm{A}, \mathrm{c}}$ & $4.19 \pm 0.92^{\mathrm{A}, \mathrm{b}}$ & $6.86 \pm 1.72^{\mathrm{A}, \mathrm{b}}$ & $4.09 \pm 1.26^{\mathrm{A}, \mathrm{a}}$ & $5.55 \pm 0.19^{\mathrm{A}, \mathrm{b}}$ \\
\hline
\end{tabular}

$\overline{\mathrm{A}, \mathrm{B}, \mathrm{C} ; \mathrm{a}, \mathrm{b}, \mathrm{c}}$ Different letters indicate significant differences (Student's t test, $\mathrm{P}<0.05)$ between mean values $( \pm \mathrm{SD}, \mathrm{n}=3)$ of lipid classes between lipid source within columns and rows, respectively. *Initial Insect Powders - Brogan et al., 2018; Initial Egg Yolk PowderAnton, 2007; Initial Krill Powder- Xie et al., 2017. EPA and DHA were not detected in insect samples. 


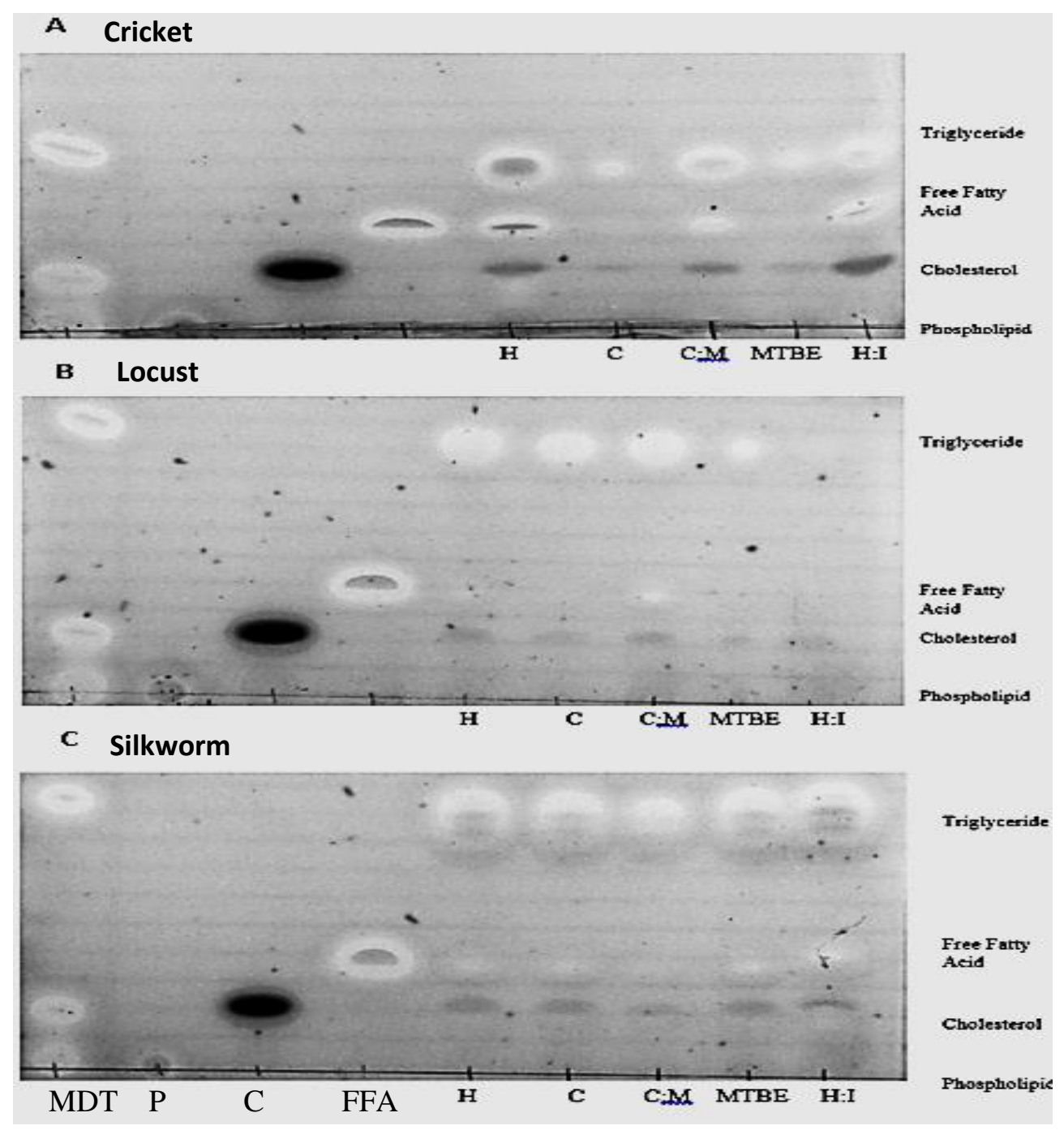

Figure 1. Separated lipid classes of cricket (A), locust (B), silkworm (C) powders following a onestep organic solvent extraction with various organic solvents. MDT=monoglyceride, diglyceride, triglyceride, $\mathrm{P}=$ phospholipid, $\mathrm{C}=$ cholesterol, $\mathrm{FFA}=$ free fatty acid standards. $\mathrm{CM}=$ ChloroformMethanol, $\mathrm{C}=$ Chloroform, $\mathrm{H}=$ Hexane, $\mathrm{HI}=$ Hexane-Isopropanol, MTBE=Methyl-Tert-Butyl-Ether 


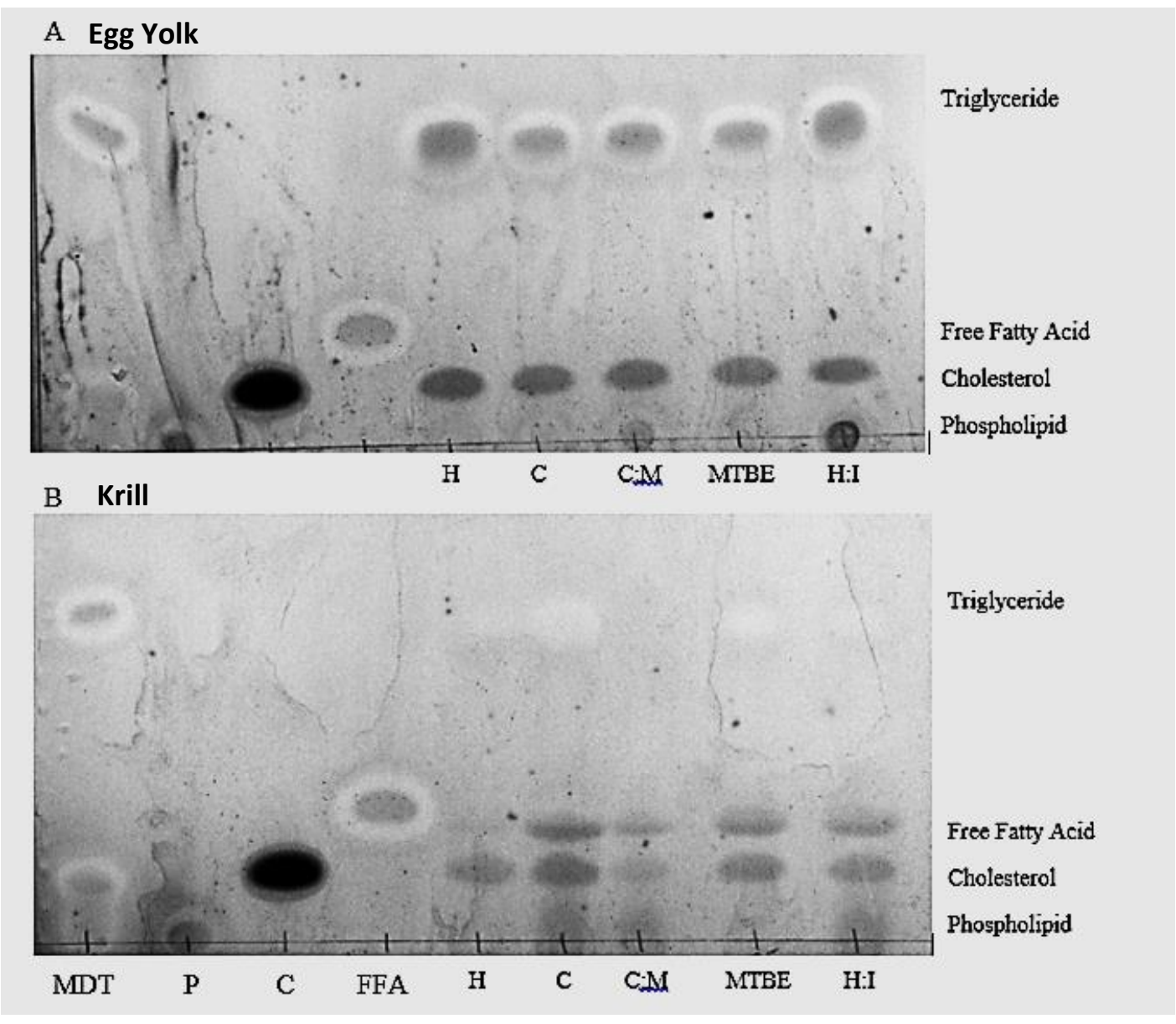

Figure 2. Separated lipid classes of egg yolk (A) and krill (B) powders following a one-step organic solvent extraction with various organic solvents. MDT=monoglyceride, diglyceride, triglyceride, $\mathrm{P}=$ phospholipid, $\mathrm{C}=$ cholesterol, $\mathrm{FFA}=$ free fatty acid standards. $\mathrm{CM}=$ ChloroformMethanol, $\mathrm{C}=$ Chloroform, $\mathrm{H}=$ Hexane, $\mathrm{HI}=$ Hexane-Isopropanol, MTBE=Methyl-Tert-Butyl-Ether 


\section{Chapter IV}

\section{Defatting insect powders to increase protein concentration}

Alleda Rose, Yu-Chun Chiu, Kang Mo Ku, Jacek Jaczynski* and Kristen Matak*

Division of Animal and Nutritional Sciences, PO Box 6108, West Virginia University, Morgantown, WV, USA

*Corresponding Authors:

Dr. Kristen Matak and Dr. Jacek Jaczynski

Contact phone: 304-293-1908; 304-293-1893

Fax: 304-293-2232

Email: kristen.matak@mail.wvu.edu; jacek.jaczynski@mail.wvu.edu

Choice of journal section where article should appear: 


\begin{abstract}
Defatting techniques are commonly used to concentrate crude protein in food sources and may be useful for enhancing protein content in insect powders. Therefore, the aim of this study was to use a one-step organic solvent (OS) lipid extraction process to remove lipid and concentrate protein from insect powders. Hexane $(\mathrm{H})$, chloroform $(\mathrm{C})$, methyl-tert-butyl ether (MTBE), 3:2 hexaneisopropanol (HI) and 2:1 chloroform-methanol (CM) were used as the extraction solvents. Samples were vortexed and centrifuged, and lipids were removed and dried. Proximate composition, SDSpage, amino acid profile, and $\mathrm{pH}$ solubility were measured on the defatted insect powders. $\mathrm{H}$ and MTBE were the most effective OS tested, with the greatest concentration of protein and lowest of lipid $(\mathrm{p}<0.05)$ in the defatted insect powders; CM was the least effective organic solvent. Differences in the polarities of the organic solvents would explain the difference in their defatting efficiencies. SDS-PAGE revealed that all defatted insect powders contained cuticle proteins, actin, hemocyanin, and myosin. The amino acid concentrations of all defatted insect powders were increased except for when $\mathrm{C}$ and $\mathrm{CM}$ were used as the OS for silkworm powder. Defatted cricket and defatted locust and silkworm powders were most soluble at $\mathrm{pH} 11$ and $\mathrm{pH}$ 12, respectively, when MTBE and H, respectively, were used as the OS. Results show H and MTBE have potential for defatting insect powders to be used as functional food.
\end{abstract}

KEYWORDS: defatting techniques, one-step organic solvent extraction, proximate composition, SDS-PAGE, protein solubility, amino acid composition 


\section{Introduction}

It is not uncommon to consume insects throughout most of the world and they prove to be an ample source of protein in regions where other sources are not widely available (Van Huis, et al., 2013). Protein content of insects varies based upon what metamorphic state they are in, but generally, adults tend to have a greater portion of protein while pupae tend to have a greater portion of lipids (Van Huis, et al., 2013). Brogan and colleagues (2018) found the crude protein content for adult cricket, adult locust, and pupae silkworm powders to be $72.0 \%, 71.20 \%, 53.07 \%$, respectively.

Defatting techniques are used to concentrate the crude protein amount in soybean, cottonseed, egg yolk, and whole pupae silkworm. Hexane is the solvent most extensively used for the defatting soybeans. L'Hocine and colleagues (2006) found the concentration of crude protein of the soybean $(85 \%)$ was increased when hexane (92.8\%), ethanol $(96.0 \%)$, and methanol $(94.0 \%)$ were used as the organic solvents; whereas, hexane, chloroform-methanol, isopropanol, hexaneisopropanol, and hexane-ethanol worked best for defatting egg yolk (Chung et al., 1991).

Defatting techniques using various organic solvents may be an option for increasing protein content in insect powders that would be used as a functional food source. Insect lipid is comprised mostly triglycerides and phospholipids and therefore, organic solvents with nonpolar and polar properties would likely extract the greatest amount of lipid. A previous study by Rose and colleagues (2019) found that when hexane $(\mathrm{H}), 3: 2$ hexane-isopropanol (H:I), chloroform (C), 2:1 chloroform-methanol (C:M), and methyl-tert-butyl-ether (MTBE) were used in a one-step organic solvent lipid extraction process for cricket, locust, and silkworm powders, the lipid extraction efficiencies were consistent with other reported research. Therefore, the purpose of this study was to evaluate the composition of defatted insect powders after they had undergone a one-step organic solvent lipid extraction method.

\section{Methods}

Adult cricket (Acheta domesticus), adult locust (Locusta migratoria), and pupae silkworm (Bombyx mori) powders were purchased from Thailand Unique (Nongsung, Thailand). Upon arrival, the insect powders were placed in a $-80^{\circ} \mathrm{C}$ freezer until needed; during analyses, they were held at $2-5^{\circ} \mathrm{C}$ throughout the experiment.

\subsection{One-step Organic Solvent Extraction}


A one-step lipid extraction with different organic solvents as described by Rose and colleagues (2018) was performed on each cricket powder, locust powder, and silk worm powder. Organic solvents used were hexane, hexane-isopropanol (3:2, v:v), chloroform, chloroformmethanol (2:1, v:v), and methyl-tert-butyl ether. Briefly, $3 \mathrm{~g}$ of sample was placed into a $35 \mathrm{~mL}$ Teflon-lined screw-capped Pyrex glass centrifuge test tube. Organic solvent was added (30 mL) to make a 1:10 ratio between sample:solvent. The test tube was vortexed for $60 \mathrm{~s}$ then transferred to a $250 \mathrm{~mL}$ beaker with an aluminum top to prevent the solvent from evaporating. The beaker was placed on a stir plate with a proportional stir bar without heat for 15 min. The sample was transferred back to a $35 \mathrm{~mL}$ Teflon-lined screw-capped Pyrex glass centrifuge tube and centrifuged at $900 \mathrm{x} \mathrm{g}$, at $10^{\circ} \mathrm{C}$ for $10 \mathrm{~min}$. The lipid layer was discarded and the test tube with the defatted powder was left overnight to dry for further analyses.

\subsection{Proximate Composition}

Proximate composition of the defatted cricket, locust, and silkworm powders was determined by measuring moisture, ash, crude lipid, and crude protein. Results were recorded as the mean value (SD) of the triplicate of each analysis.

The oven drying method was used to determine the moisture content of the sample. Samples measuring 0.5-1 grams were placed in a drying oven (Stabil Therm Gravity Oven, Blue M Electric Company, Blue Island, IL) at $110^{\circ} \mathrm{C}$ and held overnight. The following formula was used to determine the moisture content (ASTM, 1993):

Dry content $=\frac{\text { Dried } \text { Weight }}{\text { Initial Sample Weight }} \times 100$

Moisture content $(\%)=100-\%$ Dried weight

The ash content of the samples was measured by dry ashing where the oven-dried samples were placed into a muffle furnace for $24 \mathrm{hrs}$ at $550^{\circ} \mathrm{C}$ (Otto et al., 2009). The ash content was calculated by using the following formula (ASTM, 1993):

Ash content $(\%)=\frac{\text { Dried weight }}{\text { Initial weight }} \times 100$

The Kjeldahl assay was used to verify crude protein content. There were three steps to this assay: sample digestion, distillation, and titration. The number of moles of base was subtracted from the number of moles of acid used in the titration in order to give the moles of nitrogen. Once the number of moles of nitrogen in the sample was determined, it was multiplied by 14.0067 (Nitrogen's atomic mass) to determine grams of nitrogen. In order to determine grams of protein, 
the grams of nitrogen was multiplied by 6.25 . To determine the dry percent of protein, the gram of protein was divided by the percent dry weight divided by 100 (Chen and Jaczynski, 2007).

The Soxhlet extraction method was used to calculate the lipid content of the samples. An aliquot ( $1 \mathrm{~g}$ ) of each sample was placed onto filter paper (Fisherbrand, Q8, Pittsburgh, PA, USA) and into the Soxhlet apparatus for $24 \mathrm{hrs}$ with a petroleum ether drip rate of $10 \mathrm{~mL} / \mathrm{min}$ (Otto et al., 2009). Total lipid content was determined by the following equations, representatively (AOAC, 1995, Chen and Jaczynski, 2007):

Wet Lipid content $(\%)=\frac{(\text { Initial Weight }- \text { Dry Sample Weight })-g \text { moisture per sample }}{\text { Initial Sample Weight }} \times 100$

Dry Lipid content $(\%)=\frac{\text { Wet Lipid Content }}{\left(\% \frac{d r y}{100}\right)}$

\subsection{Sodium dodcecyl sulphate-polyacrylimide gel electrophoresis (SDS-Page)}

SDS-PAGE was conducted on defatted insect powders. Samples containing $50 \mu \mathrm{g}$ of protein were loaded into three $15 \%$ Tris- $\mathrm{HCl}$ separating gels (Ready Gels for electrophoresis, Bio Rad Laboratories, Hercules, CA). Gels were run at a constant $200 \mathrm{~V}$ and a 15-20mA current using a PowerPac Basic power supply (Bio Rad Laboratories, Hercules, CA) in a Mini-Protein 3 Cell (Bio Rad Laboratories, Hercules, CA). Next, gels were rinsed three times with $\mathrm{dd}_{2} \mathrm{O}$ for 5 min each per gel, stained with Bio-Safe Coomassie stain and placed on a plate shaker (LAB-LINE Instruments, Melrose Park, IL) for $1 \mathrm{hr}$. All stain was removed and the gels were rinsed with 200mL of $\mathrm{diH}_{2} \mathrm{O}$ for 30mins. Pictures of the gels were taking using GelDocing system (Bio-Rad Gel Doc $\mathrm{XR}+$ and ChemiDoc XRS+ Imaging Systems with Image Lab Software Version 6, California, United States).

\subsection{Amino Acid Composition}

A $15 \mathrm{mg}$ sample of each original insect powder and the defatted insect powders were placed in a screw top test tube and amino acid composition was measured in triplicate. $100 \mu \mathrm{L}$ of $6 \mathrm{M} \mathrm{HCl}$ was added to each test tube then set in an oven at $110^{\circ} \mathrm{C}$ for $22 \mathrm{hrs}$. Protein hydrolysates were analyzed by GC-MS procedure according to the EZ:faast manual (Phenomenex, Madrid, CA).

\subsection{Protein Solubility}

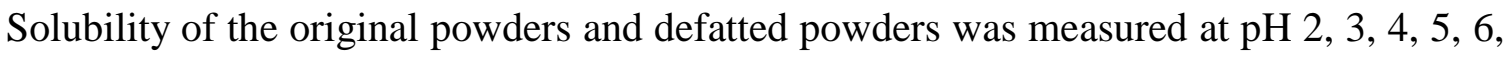
$7,8,9,10,11$, and 12 solutions. Based on the results of the proximate composition, powders defatted using MTBE and $\mathrm{H}$ had the greatest protein concentration $(\mathrm{P}<0.05)$ and thus were used as the organic solvent. A $2.0 \mathrm{~g}$ sample of each powder was placed in a $250 \mathrm{~mL}$ glass beaker with 
$20 \mathrm{~mL}$ of distilled deionized water $\left(\mathrm{ddH}_{2} \mathrm{O}\right)$ and a Teflon coated stir bar and stirred for $15 \mathrm{~min}$ on a stir plate. A calibrated Oakton pH 11 series meter (Oakton, Eutech Instruments, Singapore) was used to record initial $\mathrm{pH}$ after the $15 \mathrm{~min}$ stir period and when adjusting sample $\mathrm{pH}$ with 1:1 hydrochloric acid and $0.10 \mathrm{M}$ sodium hydroxide. Once adjusted to the desired $\mathrm{pH}$, the sample was stirred for an additional $15 \mathrm{~min}$. Upon completion, $5 \mathrm{~mL}$ of the solution was removed via pipette and placed into a plastic centrifuge tube. Samples were centrifuged at $10,000 \mathrm{x} \mathrm{g}$ for $10 \mathrm{~min}$ at $21^{\circ} \mathrm{C}$.

Upon centrifugation completion, the tubes were removed and $5 \mu \mathrm{L}$ of the supernatant was placed into a well on a 96 well plate. $250 \mu \mathrm{L}$ of Bradford's reagent was added to each well and the

plate was placed on an orbital shaker and allowed to develop for 5 minutes. The plate was placed into a plate reader spectrophotometer and absorbance was measured at a wavelength of $595 \lambda$. Bovine serum albumin was used to create a standard curve to interpret the absorbance data from the insect samples. Bovine serum albumin at concentrations of $0.125,0.25,0.5,0.75,1.0,1.5$, and $2 \mathrm{mg} / \mathrm{mL}$ was used (Bio-Rad, Hercules, CA, USA). This curve was completed in triplicate. This curve allowed us to use absorbance data to determine percent solubility.

\subsection{Statistical Design}

The defatting extractions were performed in triplicate $(n=3)$. For each triplicate, at least three measurements were performed for each assay. One-way independent measures analysis of variance (ANOVA) was used to determine individual differences between treatments. Post-hoc analysis was conducted using Student's t-test with a significance level of $(\mathrm{P}<0.05)$. ANOVA statistical comparisons were conducted using SAS JMP version 13 (SAS Institute Inc., North Carolina, USA).

\section{Results and Discussion}

\subsection{Proximate Composition of defatted insect powders}

Table 1 shows that the defatted insect powders were composed of predominantly protein and the concentration of protein varied depending on which organic solvent was used $(\mathrm{P}<0.05)$. For all insect powders, MTBE and $\mathrm{H}$ were the most effective at defatting and concentrating protein $(\mathrm{P}<0.05)$. Differences in the polarities of the organic solvents would explain the differences in their defatting efficiencies. Since insect lipid is primarily nonpolar, containing mostly triglycerides, MTBE and H worked best since they are nonpolar organic solvents. Rose and colleagues (2019) stated MTBE and $\mathrm{H}$ produced greater lipid extraction efficiencies when compared to the other 
organic solvents with the exception of CM. Hexane is a hydrocarbon which is nonpolar and is a good solvent for lipids with low polarity, thus, triglycerides are very soluble, and phospholipids are moderately soluble in this solvent (Baümler et al., 2010). MTBE is part of the alkyl ethers chemical class which is more polar than hydrocarbons, but less polar than alcohols, thus it will extract nonpolar and polar lipids (Matyash et al., 2008). Purschke and colleagues (2018) stated similar findings when defatting locust (Locusta migratoria) powder with hexane; protein content increased from $65.87 \%$ (original locust powder) to $82.26 \%$ (defatted locust powder using hexane) as well as lipid content decreased from $23.81 \%$ (original locust powder) to $3.27 \%$ (defatted locust powder using hexane).

Results from a previous study showed CM to have the greatest lipid extraction efficiency (Rose et al., 2019); however, results from this current study showed that the concentration of protein in the defatted insect powders was less than and the concentration of lipid was more than the original powders, respectively. L'Hocine and colleagues (2006) when soybeans were defatted resulted in $\mathrm{H}$ being the best extraction followed by ethanol, and methanol. $\mathrm{CM}$ has nonpolar and polar properties for extracting lipids however the methanol portion being polar is less efficient in removing the less polar lipids than hexane making methanol a poor choice for defatting (L'Hocine et al., 2006). The moisture contents of the defatted insect powders were most similar to the original powder when $\mathrm{H}, \mathrm{C}$, and MTBE were used as organic solvents $(\mathrm{P}<0.05)$. CM and HI presented with slightly greater moisture content for the defatted insect powders when compared to the original powder. Ash content of the defatted locust and silkworm powders were most like the original powder (Table $1 ; \mathrm{P}>0.05$ ) but the ash content for defatted cricket powder was less than the original powder for all organic solvents $(\mathrm{P}<0.05)$.

3.2 Sodium dodcecyl sulphate-polyacrylimide gel electrophoresis (SDS-Page) of defatted insect powders

The range of proteins contained in the defatted insect powders are shown in Figure 1. Differences in protein band patterns are apparent between species and organic solvents used. Protein bands in the defatted cricket powder were prominent at molecular weights of 20, 25, 50, 75 , and $150 \mathrm{kD}$ for all organic solvents. Defatted locust powder had protein bands that were prominent at molecular weights of $50,75,100$, and $150 \mathrm{kD}$ for all organic solvents. Protein bands in defatted silkworm powder were prominent at molecular weights of 20, 27, 37, 50, 75, and 100 
$\mathrm{kD}$ for all organic solvents. The SDS-PAGE gel for the original insect powders had protein bands at molecular weights of 14-32, 40-75, and 100-250kD (Brogan et al., 2018).

The protein bands that prominently appear in the defatted insect powders could be cuticle proteins $(14-32 \mathrm{kD})$, actin $(50 \mathrm{kD})$, hemocyanin $(75 \mathrm{kD})$, and myosin (100-150kD). Cuticle proteins are structural materials that make up the exoskeleton of the insects that interact with chitin filament (Anderson et al., 1995). Actin plays a crucial role in muscle movement along with myosin. Actin and myosin are two groups of proteins that bind to allow muscle contraction (Cooper, 2000). Myosin has another role being responsible for gel formation in processed meat products (Wang et al., 1996). The gelling capacity of food proteins is an important functional attribute. If the suspected bands at $100-150 \mathrm{kD}$ are myosin, these insect powders may have the capability to form gels; therefore having the potential as a functional food.

\subsection{Essential Amino acid (EAA) composition of defatted insect powders}

Essential amino acid composition of the defatted insect powders is shown in Table 2. There were differences in EAA concentrations depending on organic solvent used. For the most part, the amino acid concentrations were greater $(\mathrm{P}<0.05)$ in all the defatted insect powders except for methionine and tryptophan $(\mathrm{P}>0.05)$ for all organic solvents. $\mathrm{H}$ and $\mathrm{HI}$ extracted the best $(\mathrm{P}<0.05)$ EAA composition for all three defatted insect powders. Amino acid solubility is dependent on both the polar and nonpolar portions of the molecule (Needham, 1970). Most of the EAAs are hydrophobic $\mathrm{H}$ and $\mathrm{HI}$ worked best due to being nonpolar organic solvents, thus the "likes dissolves likes" statement holds true here (Cerkowniak et al., 2013). Teh and colleagues (2014) stated similar findings when defatting hemp meal with hexane. The essential amino acid profile of the defatted hemp meal was greater than $(\mathrm{P}<0.0001)$ than the untreated hemp meal. This indicates that the presence of lipid likely interferes with the hydrolysis of the amino acids during analysis of the untreated hemp meal.

\subsection{Protein Solubility}

Solubility results are shown in Table 3 and Figures 2, 3, and 4. For all insect powders, overall solubility was decreased when using $\mathrm{H}$ and MTBE in comparison to the original insect powders $(\mathrm{P}<0.05)$. These organic solvents could have partly denatured the proteins causing the

reduced solubility (Rezig et al., 2013). The defatted insect powders using MTBE and H had the greatest solubility at $\mathrm{pH} \mathrm{11(cricket)} \mathrm{and} 12$ (locust and silkworm) which is most similar to the greatest solubility at a $\mathrm{pH}$ of 12 for the original insect powders $(\mathrm{P}>0.05)$. This trend is similar to 
findings of L'Hocine (2006) who reported that the defatting process using hexane, ethanol, and methanol of soybeans did not affect the protein solubility.

\section{Conclusion}

Based on the present study, defatting insect powders (cricket, locust, silkworm) using a one-step organic solvent extraction with various organic solvents and combinations (hexane, chloroform, chloroform-methanol, methyl-tert-butyl-ether, hexane-isopropanol) H and MTBE resulted in the highest lipid extraction and increased the protein concentration in all three powders. This method shows $\mathrm{H}$ and MTBE have potential for defatting insect powders to be used in foods, and more studies need to be done to increase the protein quality and test purity; other functionality tests (emulsifying properties, foaming capacity, water holding capacity, and gelling capacity) to further determine if these insect powders could be utilized as a functional food source. 


\section{References}

1. Andersen, S., Hojrup, P., \& Roepstorff. 1995. Insect cuticular proteins. Insect Biochemistry and Molecular Biology, 25(2), 153-176. doi:10.1016/0965-1748(94)00052$\mathrm{J}$

2. Association of Official Analytical Chemists (AOAC). 1995. Offical Methods of Analysis, $16^{\text {th }}$ ed.; Association of Offical Analytical Chemists: Washington, DC.

3. ASTM D 2974-87 Standard Test Methods for Mositure, Ash, and Organic Matter of Peat and Other Organic soils. 1993. Retrieved from: http://turf.msu.edu/1990s/1993/930331.pdf

4. Baülmer, E., Guillermo, H., \& Carelli, A.A. 2010. Solvent extraction: kinetic study of major and minor compounds. JAOCS. 12; 1489-1495.

5. Brogan, E., Jaczynski, J., \& Park, Y.L. 2017. Biochemical properties of insect flours. From Poster Presentation

6. Cerkowniak, M., Puckowski, A., Stepnowski, P., \& Golebiowski, M. 2013. The use of chromatographic techniques for the separation and the identification of insect lipids. Journal of Chromatography B. 937; 67-78.

7. Chen, Y.C., \& Jaczynski, J. 2007. Protein recovery from rainbow trout (Oncorhynchus myskiss) processing by-products via isoelectric solubilization / precipitation and its gelation properties as affected by functional additives. Journal of Agricultural and Food Chemistry. 55; 9079-9088.

8. Chung, S., \& Ferrier, L.K. 1999. Partial lipid extraction of egg yolk powder: effects on emulsifying properties and soluble protein fractions. Journal of Food Science. 56; 5.

9. Cooper, G. 2000. Actin, Myosin, and Cell Movement. In The Cell: A Molecular Approach. Sunderland, MA, USA: Sinauer Associates. Retrieved 2018, from https://www.ncbi.nlm.nih.gov/books/NBK9961/

10. JMP, Version 13 SAS Institute Inc., Cary, NC, 1989-2017.

11. L'Hocine, L., Boye, J.I., \& Arcand, Y. 2006. Composition and functional properties of soy protein isolates prepared using alternative defatting and extraction procedures. Journal of Food Science. 71;3. 
12. Matyash, V., Liebisch, G., Kurzchalia, T.V., Shevchenko, A., \& Schwudke, D. 2008. Lipid extraction by methyl-tert-butyl ether for high-throughput lipidomics. J Lipid Res. 49(5); 11371146.

13. Needham, T. The solubility of amino acids in various solvent systems. Open Access Dissertations. Paper 159.

14. Otto, R. A., Beamer, S., Jaczynski, J., Matak, K. E. 2009. Survival of Listeria innocua after Isoelectric Solubilization/Precipitation with Acetic and Citric Acids Manuscript.

15. Purschke, B., Tanzmeister, H., Meinlschmidt, P., Baumgarter, S., Lauter, K., \& Jager, H. 2018. Recovery of soluble proteins from migratory locust (Locusta migratoria) and characterization of their compositional and techno-functional properties. Journal of Food Research International. 106; 271-279.

16. Rezig, L., Chibani, F., Chouaibi, M., Dalgalarrondo, M., \& Hessini, K. 2013. Pumpkin (Curcurbita maxima) seed proteins: sequential extraction processing and fraction characterization. Journal of Agricultural and Food Chemistry. 61(32); 7715-7721.

17. Rose, A., Jaczynski, J., \& Matak, K. 2019. Extraction of lipids from insect, krill, and egg yolk powders using a one-step organic solvent extraction process.

18. Teh, S., Carne, A., Bekhit, A., \& Birch, E.J. 2014. Effect of the defatting process, acid and alkali extraction on the physicochemical and functional properities of hemp, flax, and canola seed cake protein isolates. Food Measure. 8; 92-104.

19. Van Huis, A., van Itterbeeck, J., Klunder, H., Mertens, E., Halloran, A., Muir, G., \& Vantomme, P. 2013. Edible insects: future prospects for food and feed security. Food and Agricultural Organization. Retrieved from http://www.fao.org/docrep/018/i3253e.pd

20. Wang, S.F., Smyht1, A.B., and Smith, D.M. 1996. Gelation properties of myosin: role of subfragments and actin. Macromolecular Interactions in Food Technology. 10; 124-133. 


\section{Tables and Figures}

Table 1: Proximate composition of defatted insect powders following one-step extraction with various organic solvents. Ash, crude protein and crude lipid were measured as $\mathrm{g} / 100 \mathrm{~g}$, dry basis.

\begin{tabular}{|c|c|c|c|c|c|c|c|}
\hline Proximate & Sample & $\begin{array}{l}\text { Original } \\
\text { Powder* }\end{array}$ & Hexane & Chloroform & $\begin{array}{c}\text { Chloroform- } \\
\text { Methanol }\end{array}$ & $\begin{array}{l}\text { Methyl-Tert- } \\
\text { Butyl-Ether }\end{array}$ & $\begin{array}{l}\text { Hexane- } \\
\text { Isopropanol }\end{array}$ \\
\hline \multirow[t]{3}{*}{ Moisture } & Cricket & $8.00 \pm 0.07^{\mathrm{A}, \mathrm{d}}$ & $8.27 \pm 0.40^{\mathrm{A}, \mathrm{c}}$ & $9.18 \pm 0.56^{\mathrm{A}, \mathrm{c}}$ & $12.16 \pm 0.37^{\mathrm{B}, \mathrm{b}}$ & $8.63 \pm 0.41^{\mathrm{A}, \mathrm{c}}$ & $31.25 \pm 0.07^{\mathrm{A}, \mathrm{a}}$ \\
\hline & Locust & $6.00 \pm 0.00^{\mathrm{B}, \mathrm{b}}$ & $7.59 \pm 0.34^{\mathrm{A}, \mathrm{b}}$ & $7.03 \pm 0.33^{\mathrm{A}, \mathrm{b}}$ & $13.99 \pm 0.29^{\mathrm{A}, \mathrm{a}}$ & $6.39 \pm 0.26^{\mathrm{A}, \mathrm{b}}$ & $12.45 \pm 0.12^{\mathrm{B}, \mathrm{b}}$ \\
\hline & Silkworm & $8.00 \pm 0.09^{\mathrm{C}, \mathrm{a}}$ & $4.03 \pm 0.5^{\mathrm{B}, \mathrm{b}}$ & $4.66 \pm 0.65^{\mathrm{B}, \mathrm{b}}$ & $20.28 \pm 1.89^{\mathrm{B}, \mathrm{a}}$ & $3.71 \pm 0.4^{\mathrm{B}, \mathrm{b}}$ & $15.16 \pm 0.57^{\mathrm{A}, \mathrm{a}}$ \\
\hline \multirow[t]{3}{*}{ Ash } & Cricket & $4.79 \pm 0.08^{\mathrm{A}, \mathrm{a}}$ & $3.12 \pm 0.04^{\mathrm{A}, \mathrm{a}}$ & $3.11 \pm 0.11^{\mathrm{B}, \mathrm{a}}$ & $2.33 \pm 0.06^{\mathrm{A}, \mathrm{a}}$ & $2.33 \pm 0.04^{\mathrm{B}, \mathrm{a}}$ & $3.22 \pm 0.07^{\mathrm{A}, \mathrm{a}}$ \\
\hline & Locust & $3.54 \pm 0.03^{\mathrm{B}, \mathrm{a}, \mathrm{b}}$ & $2.88 \pm 0.24^{\mathrm{A}, \mathrm{b}}$ & $4.06 \pm 0.20^{\mathrm{A}, \mathrm{a}, \mathrm{b}}$ & $6.32 \pm 0.32^{\mathrm{A}, \mathrm{a}}$ & $3.78 \pm 0.28^{\mathrm{A}, \mathrm{B}, \mathrm{a}, \mathrm{b}}$ & $4.21 \pm 0.32^{\mathrm{A}, \mathrm{a}}$ \\
\hline & Silkworm & $2.81 \pm 0.63^{\mathrm{C}, \mathrm{b}, \mathrm{c}}$ & $3.98 \pm 0.09^{\mathrm{A}, \mathrm{b}, \mathrm{c}}$ & $3.21 \pm 0.11^{\mathrm{A}, \mathrm{B}, \mathrm{c}}$ & $3.67 \pm 0.30^{\mathrm{A}, \mathrm{a}, \mathrm{b}, \mathrm{c}}$ & $4.57 \pm 0.21^{\mathrm{A}, \mathrm{a}, \mathrm{b}}$ & $5.16 \pm 0.83^{\mathrm{A}, \mathrm{a}}$ \\
\hline Crude & Cricket & $71.96 \pm 0.32^{\mathrm{A}, \mathrm{b}, \mathrm{c}}$ & $76.67 \pm 0.67^{\mathrm{Ba}, \mathrm{b}}$ & $70.38 \pm 2.03^{\mathrm{B}, \mathrm{c}}$ & $41.34 \pm 3.35^{\mathrm{A}, \mathrm{e}}$ & $79.48 \pm 0.64^{\mathrm{A}, \mathrm{a}}$ & $63.45 \pm 1.32^{\mathrm{A}, \mathrm{B}, \mathrm{d}}$ \\
\hline \multirow[t]{2}{*}{ Protein } & Locust & $71.17 \pm 0.07^{\mathrm{B}, \mathrm{d}}$ & $80.16 \pm 1.1^{\mathrm{A}, \mathrm{a}}$ & $73.67 \pm 0.62^{\mathrm{A}, \mathrm{c}}$ & $32.04 \pm 2.1^{\mathrm{B}, \mathrm{f}}$ & $80.06 \pm 1.22^{\mathrm{A}, \mathrm{b}}$ & $56.94 \pm 1.67^{\mathrm{A}, \mathrm{e}}$ \\
\hline & Silkworm & $53.07 \pm 0.11^{\mathrm{C}, \mathrm{e}}$ & $62.44 \pm 0.69^{\mathrm{C}, \mathrm{b}}$ & $55.21 \pm 0.65^{\mathrm{C}, \mathrm{d}}$ & $46.10 \pm 0.26^{\mathrm{A}, \mathrm{f}}$ & $73.89 \pm 0.52^{\mathrm{B}, \mathrm{a}}$ & $62.44 \pm 0.68^{\mathrm{A}, \mathrm{c}}$ \\
\hline Crude & Cricket & $15.39 \pm 1.05^{\mathrm{B}, \mathrm{c}}$ & $8.12 \pm 1.57^{\mathrm{A}, \mathrm{c}}$ & $18.27 \pm 1.19^{\mathrm{A}, \mathrm{B}, \mathrm{b}}$ & $61.38 \pm 2.00^{\mathrm{A}, \mathrm{a}}$ & $5.95 \pm 1.13^{\mathrm{B}, \mathrm{c}}$ & $13.03 \pm 3.27^{\mathrm{B}, \mathrm{d}}$ \\
\hline \multirow[t]{2}{*}{ Lipid } & Locust & $11.42 \pm 1.10^{\mathrm{C}, \mathrm{d}}$ & $1.25 \pm 1.17^{\mathrm{B}, \mathrm{e}}$ & $38.02 \pm 0.92^{\mathrm{A}, \mathrm{b}}$ & $58.56 \pm 1.88^{\mathrm{A}, \mathrm{a}}$ & $2.11 \pm 1.20^{\mathrm{C}, \mathrm{e}}$ & $25.50 \pm 2.42^{\mathrm{A}, \mathrm{c}}$ \\
\hline & Silkworm & $37.52 \pm 0.03^{\mathrm{A}, \mathrm{b}}$ & $11.81 \pm 1.28^{\mathrm{A}, \mathrm{f}}$ & $17.24 \pm 0.09^{\mathrm{B}, \mathrm{d}}$ & $41.60 \pm 0.32^{\mathrm{A}, \mathrm{a}}$ & $13.52 \pm 2.00^{\mathrm{A}, \mathrm{e}}$ & $27.37 \pm 1.24^{\mathrm{A}, \mathrm{c}}$ \\
\hline
\end{tabular}

${ }_{\mathrm{A}, \mathrm{B}, \mathrm{C}}$ Different letters indicate significant differences (Student's t test, $\left.\mathrm{P}<0.05\right)$ between mean values $( \pm \mathrm{SD}, \mathrm{n}=3)$ within the same column ${ }^{a, b, c}$ Different letters indicate significant differences (Student's t test, $\mathrm{P}<0.05$ ) between mean values $( \pm \mathrm{SD}$, $\mathrm{n}=3$ ) within the same row.

*Initial Powder-Brogan et al. 2018 
Table 2: Essential amino acid composition $(\mathrm{g} / 100 \mathrm{~g})$ of defatted insect powders following one-step extraction with various organic solvents.

\begin{tabular}{|c|c|c|c|c|c|c|c|}
\hline Amino Acid & Sample & $\begin{array}{l}\text { Original } \\
\text { Powder* }\end{array}$ & Hexane & Chloroform & $\begin{array}{l}\text { Chloroform- } \\
\text { Methanol }\end{array}$ & $\begin{array}{l}\text { Methyl-Tert- } \\
\text { Butyl-Ether }\end{array}$ & $\begin{array}{c}\text { Hexane- } \\
\text { Isopropanol }\end{array}$ \\
\hline \multirow[t]{3}{*}{ Valine } & Silkworm & $2.13 \pm 0.01^{\mathrm{B}, \mathrm{b}}$ & $10.35 \pm 1.13^{\mathrm{A}, \mathrm{a}}$ & $0.00 \pm 0.00^{\mathrm{B}, \mathrm{c}}$ & $0.00 \pm 0.00^{\mathrm{B}, \mathrm{a}}$ & $8.59 \pm 0.21^{\mathrm{A}, \mathrm{a}}$ & $9.65 \pm 0.91^{\mathrm{A}, \mathrm{a}}$ \\
\hline & Locust & $4.18 \pm 0.03^{\mathrm{A}, \mathrm{b}}$ & $5.48 \pm 0.78^{\mathrm{A}, \mathrm{b}}$ & $7.69 \pm 0.63^{\mathrm{A}, \mathrm{a}}$ & $9.65 \pm 0.26^{\mathrm{A}, \mathrm{a}}$ & $9.26 \pm 0.84^{\mathrm{A}, \mathrm{a}}$ & $9.26 \pm 0.84^{\mathrm{A}, \mathrm{a}}$ \\
\hline & Cricket & $3.84 \pm 0.09^{\mathrm{B}, \mathrm{b}}$ & $9.68 \pm 0.89^{\mathrm{A}, \mathrm{a}}$ & $7.58 \pm 3.04^{\mathrm{A}, \mathrm{a}}$ & $9.96 \pm 0.97^{\mathrm{A}, \mathrm{a}}$ & $10.03 \pm 2.26^{\mathrm{A}, \mathrm{a}}$ & $7.59 \pm 0.35^{\mathrm{A}, \mathrm{a}}$ \\
\hline \multirow[t]{3}{*}{ Leucine } & Silkworm & $3.70 \pm 0.01^{\mathrm{C}, \mathrm{b}}$ & $9.96 \pm 2.20^{\mathrm{A}, \mathrm{a}}$ & $2.50 \pm 3.53^{\mathrm{B}, \mathrm{b}}$ & $0.00 \pm 0.00^{\mathrm{B}, \mathrm{c}}$ & $8.35 \pm 0.77^{\mathrm{A}, \mathrm{a}}$ & $7.67 \pm 1.45^{\mathrm{A}, \mathrm{a}}$ \\
\hline & Locust & $5.04 \pm 0.02^{\mathrm{A}, \mathrm{b}}$ & $9.11 \pm 1.80^{\mathrm{A}, \mathrm{a}}$ & $8.62 \pm 2.14^{\mathrm{A}, \mathrm{a}}$ & $7.85 \pm 0.45^{\mathrm{A}, \mathrm{a}}$ & $8.00 \pm 2.12^{\mathrm{A}, \mathrm{a}}$ & $11.13 \pm 1.71^{\mathrm{A}, \mathrm{a}}$ \\
\hline & Cricket & $4.83 \pm 0.02^{\mathrm{A}, \mathrm{b}}$ & $12.21 \pm 0.57^{\mathrm{A}, \mathrm{a}}$ & $8.19 \pm 2.10^{\mathrm{A}, \mathrm{a}}$ & $8.20 \pm 1.01^{\mathrm{A}, \mathrm{a}}$ & $6.93 \pm 1.72^{\mathrm{A}, \mathrm{a}}$ & $11.39 \pm 0.71^{\mathrm{A}, \mathrm{a}}$ \\
\hline \multirow[t]{3}{*}{ Isoleucine } & Silkworm & $2.35 \pm 0.01^{\mathrm{B}, \mathrm{b}}$ & $6.90 \pm 0.56^{\mathrm{A}, \mathrm{a}}$ & $0.00 \pm 0.00^{\mathrm{B}, \mathrm{c}}$ & $0.00 \pm 0.00^{\mathrm{B}, \mathrm{c}}$ & $8.56 \pm 0.73^{\mathrm{A}, \mathrm{a}}$ & $7.24 \pm 1.39^{\mathrm{A}, \mathrm{a}}$ \\
\hline & Locust & $2.92 \pm 0.01^{\mathrm{A}, \mathrm{b}}$ & $4.44 \pm 0.74^{\mathrm{A}, \mathrm{b}}$ & $9.73 \pm 2.04^{\mathrm{A}, \mathrm{a}}$ & $6.32 \pm 1.34^{\mathrm{A}, \mathrm{a}}$ & $2.16 \pm 3.06^{\mathrm{A}, \mathrm{b}}$ & $8.41 \pm 0.73^{\mathrm{A}, \mathrm{a}}$ \\
\hline & Cricket & $2.91 \pm 0.01^{\mathrm{A}}$ & $7.85 \pm 1.36^{\mathrm{A}, \mathrm{a}}$ & $7.65 \pm 1.90^{\mathrm{A}, \mathrm{a}}$ & $7.78 \pm 0.94^{\mathrm{A}, \mathrm{a}}$ & $6.89 \pm 0.98^{\mathrm{A}, \mathrm{a}}$ & $6.49 \pm 0.84^{\mathrm{A}, \mathrm{a}}$ \\
\hline \multirow[t]{3}{*}{ Threonine } & Silkworm & $2.27 \pm 0.02^{\mathrm{C}, \mathrm{b}}$ & $3.84 \pm 0.56^{\mathrm{A}, \mathrm{b}}$ & $18.01 \pm 4.26^{\mathrm{A}, \mathrm{a}}$ & $0.85 \pm 1.20^{\mathrm{B}, \mathrm{c}}$ & $4.52 \pm 0.26^{\mathrm{A}, \mathrm{b}}$ & $4.41 \pm 0.39^{\mathrm{A}, \mathrm{b}}$ \\
\hline & Locust & $2.33 \pm 0.01^{\mathrm{B}, \mathrm{a}}$ & $3.36 \pm 1.05^{\mathrm{A}, \mathrm{a}}$ & $4.15 \pm 1.10^{\mathrm{B}, \mathrm{a}}$ & $3.23 \pm 0.38^{\mathrm{A}, \mathrm{a}}$ & $4.53 \pm 1.59^{\mathrm{A}, \mathrm{a}}$ & $3.57 \pm 0.59^{\mathrm{A}, \mathrm{a}}$ \\
\hline & Cricket & $2.54 \pm 0.02^{\mathrm{A}, \mathrm{b}}$ & $3.66 \pm 1.07^{\mathrm{A}, \mathrm{a}}$ & $5.25 \pm 1.41^{\mathrm{B}, \mathrm{a}}$ & $4.01 \pm 0.22^{\mathrm{A}, \mathrm{a}}$ & $2.07 \pm 1.85^{\mathrm{A}, \mathrm{b}}$ & $2.13 \pm 0.70^{\mathrm{A}, \mathrm{b}}$ \\
\hline \multirow[t]{3}{*}{ Phenylalanine } & Silkworm & $2.68 \pm 0.06^{\mathrm{A}, \mathrm{b}}$ & $8.21 \pm 0.18^{\mathrm{A}, \mathrm{a}}$ & $0.00 \pm 0.00^{\mathrm{A}, \mathrm{c}}$ & $0.00 \pm 0.00^{\mathrm{B}, \mathrm{c}}$ & $5.69 \pm 0.79^{\mathrm{A}, \mathrm{a}}$ & $6.05 \pm 0.63^{\mathrm{A}, \mathrm{a}}$ \\
\hline & Locust & $2.03 \pm 0.01^{\mathrm{C}, \mathrm{b}}$ & $4.81 \pm 1.64^{\mathrm{A}, \mathrm{a}}$ & $3.90 \pm 1.12^{\mathrm{A}, \mathrm{a}}$ & $2.53 \pm 0.33^{\mathrm{A}, \mathrm{b}}$ & $3.15 \pm 1.42^{\mathrm{A}, \mathrm{a}, \mathrm{b}}$ & $4.40 \pm 0.99^{\mathrm{A}, \mathrm{a}}$ \\
\hline & Cricket & $2.34 \pm 0.02^{\mathrm{B}, \mathrm{b}}$ & $6.18 \pm 0.95^{\mathrm{A}, \mathrm{a}}$ & $3.85 \pm 1.07^{\mathrm{A}, \mathrm{b}}$ & $3.31 \pm 0.27^{\mathrm{A}, \mathrm{b}}$ & $4.30 \pm 0.16^{\mathrm{A}, \mathrm{a}}$ & $7.74 \pm 0.29^{\mathrm{A}, \mathrm{a}}$ \\
\hline \multirow[t]{3}{*}{ Lysine } & Silkworm & $3.68 \pm 0.04^{\mathrm{B}, \mathrm{b}}$ & $3.96 \pm 0.71^{\mathrm{A}, \mathrm{b}}$ & $6.04 \pm 0.00^{\mathrm{A}, \mathrm{a}}$ & $0.00 \pm 0.00^{\mathrm{B}, \mathrm{c}}$ & $4.48 \pm 0.29^{\mathrm{A}, \mathrm{a}, \mathrm{b}}$ & $4.40 \pm 0.95^{\mathrm{A}, \mathrm{a}, \mathrm{b}}$ \\
\hline & Locust & $3.64 \pm 0.02^{\mathrm{B}, \mathrm{b}}$ & $5.15 \pm 1.14^{\mathrm{A}, \mathrm{a}}$ & $3.50 \pm 0.54^{\mathrm{A}, \mathrm{b}}$ & $3.46 \pm 0.56^{\mathrm{A}, \mathrm{b}}$ & $2.92 \pm 0.22^{\mathrm{A}, \mathrm{b}}$ & $3.62 \pm 0.00^{\mathrm{A}, \mathrm{b}}$ \\
\hline & Cricket & $3.90 \pm 0.03^{\mathrm{A}, \mathrm{a}}$ & $3.82 \pm 0.00^{\mathrm{A}, \mathrm{a}}$ & $2.64 \pm 0.43^{\mathrm{A}, \mathrm{a}, \mathrm{b}}$ & $4.16 \pm 0.28^{\mathrm{A}, \mathrm{a}}$ & $2.40 \pm 0.38^{\mathrm{A}, \mathrm{a}, \mathrm{b}}$ & $4.25 \pm 0.15^{\mathrm{A}, \mathrm{a}}$ \\
\hline \multirow[t]{3}{*}{ Histidine } & Silkworm & $1.69 \pm 0.03^{\mathrm{B}, \mathrm{c}}$ & $2.46 \pm 0.24^{\mathrm{A}, \mathrm{c}}$ & $20.29 \pm 0.87^{\mathrm{A}, \mathrm{a}}$ & $1.00 \pm 1.74^{\mathrm{A}, \mathrm{c}}$ & $7.96 \pm 0.50^{\mathrm{A}, \mathrm{b}}$ & $6.15 \pm 0.33^{\mathrm{A}, \mathrm{b}}$ \\
\hline & Locust & $1.56 \pm 0.00^{\mathrm{A}, \mathrm{b}}$ & $2.14 \pm 1.97^{\mathrm{A}, \mathrm{b}}$ & $0.93 \pm 1.05^{\mathrm{B}, \mathrm{b}}$ & $4.72 \pm 0.55^{\mathrm{A}, \mathrm{a}}$ & $2.07 \pm 0.95^{\mathrm{A}, \mathrm{b}}$ & $1.88 \pm 0.88^{\mathrm{B}, \mathrm{b}}$ \\
\hline & Cricket & $1.52 \pm 0.05^{\mathrm{A}, \mathrm{b}}$ & $3.35 \pm 1.53^{\mathrm{A}, \mathrm{a}}$ & $1.26 \pm 1.21^{\mathrm{B}, \mathrm{b}}$ & $4.41 \pm 0.30^{\mathrm{A}, \mathrm{a}}$ & $0.32 \pm 0.28^{\mathrm{B}, \mathrm{c}}$ & $1.99 \pm 0.43^{\mathrm{B}, \mathrm{b}}$ \\
\hline \multirow[t]{3}{*}{ Methionine } & Silkworm & $1.49 \pm 0.02^{\mathrm{A}, \mathrm{b}}$ & $0.62 \pm 0.02^{\mathrm{A}, \mathrm{c}, \mathrm{d}}$ & $2.20 \pm 0.00^{\mathrm{A}, \mathrm{a}}$ & $0.41 \pm 0.02^{\mathrm{A}, \mathrm{c}, \mathrm{d}}$ & $0.64 \pm 0.69^{\mathrm{A}, \mathrm{c}}$ & $0.00 \pm 0.00^{\mathrm{A}, \mathrm{d}}$ \\
\hline & Locust & $0.90 \pm 0.00^{\mathrm{C}, \mathrm{a}}$ & $0.00 \pm 0.00^{\mathrm{B}, \mathrm{e}}$ & $0.22 \pm 0.29^{\mathrm{B}, \mathrm{c}}$ & $0.10 \pm 0.02^{\mathrm{C}, \mathrm{d}}$ & $0.19 \pm 0.04^{\mathrm{A}, \mathrm{c}}$ & $0.29 \pm 0.03^{\mathrm{A}, \mathrm{b}}$ \\
\hline & Cricket & $1.10 \pm 0.01^{\mathrm{B}, \mathrm{a}}$ & $0.19 \pm 0.6^{\mathrm{B}, \mathrm{b}}$ & $0.22 \pm 0.06^{\mathrm{B}, \mathrm{b}}$ & $0.24 \pm 0.08^{\mathrm{B}, \mathrm{b}}$ & $0.24 \pm 0.08^{\mathrm{A}, \mathrm{b}}$ & $0.29 \pm 0.05^{\mathrm{A}, \mathrm{b}}$ \\
\hline \multirow[t]{3}{*}{ Tryptophan } & Silkworm & $0.90 \pm 0.02^{\mathrm{A}, \mathrm{a}}$ & $0.02 \pm 0.01^{\mathrm{A}, \mathrm{b}}$ & $0.02 \pm 0.02^{\mathrm{A}, \mathrm{b}}$ & $0.00 \pm 0.00^{\mathrm{A}, \mathrm{b}}$ & $0.02 \pm 0.03^{\mathrm{A}, \mathrm{b}}$ & $0.00 \pm 0.00^{\mathrm{A}, \mathrm{b}}$ \\
\hline & Locust & $0.52 \pm 0.02^{\mathrm{C}, \mathrm{a}}$ & $0.00 \pm 0.00^{\mathrm{B}, \mathrm{b}}$ & $0.00 \pm 0.00^{\mathrm{A}, \mathrm{b}}$ & $0.00 \pm 0.00^{\mathrm{A}, \mathrm{b}}$ & $0.00 \pm 0.00^{\mathrm{A}, \mathrm{b}}$ & $0.00 \pm 0.00^{\mathrm{A}, \mathrm{b}}$ \\
\hline & Cricket & $0.68 \pm 0.02^{\mathrm{B}, \mathrm{a}}$ & $0.00 \pm 0.00^{\mathrm{B}, \mathrm{b}}$ & $0.68 \pm 0.00^{\mathrm{A}, \mathrm{b}}$ & $0.00 \pm 0.00^{\mathrm{A}, \mathrm{b}}$ & $0.00 \pm 0.00^{\mathrm{A}, \mathrm{b}}$ & $0.00 \pm 0.00^{\mathrm{A}, \mathrm{b}}$ \\
\hline
\end{tabular}

$\overline{\mathrm{A}, \mathrm{B}, \mathrm{C}}$ Different letters indicate significant differences (Student's t test, $\mathrm{P}<0.05)$ between mean values $( \pm \mathrm{SD}, \mathrm{n}=3$ ) within the column.

a,b,c Different letters indicate significant differences (Student's t test, $\mathrm{P}<0.05$ ) between mean values $( \pm \mathrm{SD}$, $\mathrm{n}=3$ ) within the same row.

*Initial Powder- Brogan et al., 2018 
Table 3: Protein Solubility (\%) of original insect and defatted insect powders

\begin{tabular}{|c|c|c|c|c|}
\hline pH & $\begin{array}{c}\text { Powder } \\
\text { Type }\end{array}$ & Original* $^{*}$ & Hexane & MTBE \\
\hline \multirow[t]{3}{*}{2} & Cricket & $23.47 \pm 6.11^{\mathrm{B}, \mathrm{a}}$ & $14.82 \pm 0.37^{\mathrm{A}, \mathrm{a}}$ & $19.77 \pm 0.27^{\mathrm{A}, \mathrm{a}}$ \\
\hline & Locust & $25.54 \pm 0.90^{\mathrm{A}, \mathrm{B}, \mathrm{a}}$ & $21.63 \pm 1.34^{\mathrm{A}, \mathrm{a}, \mathrm{b}}$ & $12.83 \pm 5.75^{\mathrm{A}, \mathrm{b}}$ \\
\hline & Silkworm & $31.70 \pm 1.62^{\mathrm{C}, \mathrm{a}}$ & $21.65 \pm 1.93^{\mathrm{A}, \mathrm{b}}$ & $20.59 \pm 5.95^{\mathrm{A}, \mathrm{b}}$ \\
\hline \multirow[t]{3}{*}{3} & Cricket & $17.51 \pm 1.42^{\mathrm{A}, \mathrm{a}}$ & $5.04 \pm 0.14^{\mathrm{B}, \mathrm{b}}$ & $6.22 \pm 3.82^{\mathrm{B}, \mathrm{b}}$ \\
\hline & Locust & $13.93 \pm 9.24^{\mathrm{A}, \mathrm{a}}$ & $13.23 \pm 0.74^{\mathrm{A}, \mathrm{B}, \mathrm{a}}$ & $7.69 \pm 4.79^{\mathrm{A}, \mathrm{B}, \mathrm{a}}$ \\
\hline & Silkworm & $16.41 \pm 5.61^{\mathrm{A}, \mathrm{a}}$ & $13.90 \pm 3.69^{\mathrm{A}, \mathrm{a}}$ & $15.77 \pm 5.11^{\mathrm{A}, \mathrm{a}}$ \\
\hline \multirow[t]{3}{*}{4} & Cricket & $7.26 \pm 2.00^{\mathrm{C}, \mathrm{a}}$ & $3.33 \pm 0.57^{\mathrm{A}, \mathrm{b}}$ & $4.74 \pm 2.18^{\mathrm{B}, \mathrm{a}, \mathrm{b}}$ \\
\hline & Locust & $11.85 \pm 0.56^{\mathrm{B}, \mathrm{a}}$ & $8.60 \pm 0.25^{\mathrm{A}, \mathrm{a}}$ & $9.08 \pm 3.86^{\mathrm{A}, \mathrm{B}, \mathrm{a}}$ \\
\hline & Silkworm & $16.17 \pm 2.54^{\mathrm{A}, \mathrm{a}}$ & $4.64 \pm 3.58^{\mathrm{A}, \mathrm{b}}$ & $22.03 \pm 1.23^{\mathrm{A}, \mathrm{a}}$ \\
\hline \multirow[t]{3}{*}{5} & Cricket & $8.07 \pm 1.35^{\mathrm{A}, \mathrm{a}}$ & $2.31 \pm 0.73^{\mathrm{B}, \mathrm{b}}$ & $7.05 \pm 3.31^{\mathrm{A}, \mathrm{a}}$ \\
\hline & Locust & $7.71 \pm 0.76^{\mathrm{A}, \mathrm{a}}$ & $10.09 \pm 3.81^{\mathrm{A}, \mathrm{a}}$ & $13.80 \pm 5.68^{\mathrm{A}, \mathrm{a}}$ \\
\hline & Silkworm & $7.42 \pm 2.73^{\mathrm{A}, \mathrm{a}, \mathrm{b}}$ & $3.17 \pm 1.98^{\mathrm{B}, \mathrm{b}}$ & $10.06 \pm 2.58^{\mathrm{A}, \mathrm{a}}$ \\
\hline \multirow[t]{3}{*}{6} & Cricket & $16.27 \pm 2.28^{\mathrm{A}, \mathrm{a}}$ & $3.45 \pm 3.51^{\mathrm{B}, \mathrm{b}}$ & $9.64 \pm 3.83^{\mathrm{A}, \mathrm{b}}$ \\
\hline & Locust & $4.00^{\mathrm{A}, \mathrm{a}}$ & $20.01 \pm 0.20^{\mathrm{A}, \mathrm{a}}$ & $17.33 \pm 4.24^{\mathrm{A}, \mathrm{a}}$ \\
\hline & Silkworm & 12.72 & $4.23 \pm$ & $10.05 \pm 3.59^{\mathrm{A}, \mathrm{a}}$ \\
\hline \multirow[t]{3}{*}{7} & Cricket & $17.74 \pm 4.37^{\mathrm{A}, \mathrm{a}}$ & $3.10 \pm 2.99^{\mathrm{B}, \mathrm{b}}$ & $14.87 \pm 2.38^{\mathrm{A}, \mathrm{B}, \mathrm{a}}$ \\
\hline & Locust & $17.24 \pm 2.06^{\mathrm{A}, \mathrm{a}}$ & $20.36 \pm 0.84^{\mathrm{A}, \mathrm{a}}$ & $21.68 \pm 6.07^{\mathrm{A}, \mathrm{a}}$ \\
\hline & Silkworm & $10.41 \pm 2.92^{\mathrm{A}, \mathrm{a}}$ & $4.94 \pm$ & $12.05 \pm 2.43^{\mathrm{B}, \mathrm{a}}$ \\
\hline \multirow[t]{3}{*}{8} & Cricket & $21.98 \pm 9.11^{\mathrm{A}, \mathrm{a}}$ & $5.49 \pm 3.68^{\mathrm{B}, \mathrm{b}}$ & $14.90 \pm 2.99^{\mathrm{A}, \mathrm{B}, \mathrm{a}, \mathrm{b}}$ \\
\hline & Locust & $19.15 \pm 0.22^{\mathrm{A}, \mathrm{a}}$ & $17.34 \pm 4.21^{\mathrm{A}, \mathrm{a}}$ & $24.12 \pm 6.25^{\mathrm{A}, \mathrm{a}}$ \\
\hline & Silkworm & $17.69 \pm 2.10^{\mathrm{A}, \mathrm{a}}$ & $10.20 \pm 1.40^{\mathrm{B}, \mathrm{b}}$ & $14.16 \pm 4.33^{\text {В,a, }}$ \\
\hline \multirow[t]{3}{*}{9} & Cricket & $25.37 \pm 6.18^{\mathrm{A}, \mathrm{a}}$ & $7.80 \pm 1.22^{\mathrm{B}, \mathrm{b}}$ & $20.33 \pm 1.99^{\mathrm{A}, \mathrm{a}}$ \\
\hline & Locust & $21.45 \pm 1.47^{\mathrm{A}, \mathrm{a}}$ & $26.03 \pm 1.80^{\mathrm{A}, \mathrm{a}}$ & $30.60 \pm 0.29^{\mathrm{A}, \mathrm{a}}$ \\
\hline & Silkworm & $20.10 \pm 2.95^{\mathrm{A}, \mathrm{a}}$ & $12.75 \pm 4.66^{\mathrm{A}, \mathrm{B}, \mathrm{a}}$ & $18.63 \pm 3.63^{\mathrm{A}, \mathrm{a}}$ \\
\hline \multirow[t]{3}{*}{10} & Cricket & $29.28 \pm 7.06^{\mathrm{A}, \mathrm{a}}$ & $13.57 \pm 3.08^{\mathrm{B}, \mathrm{b}}$ & $23.14 \pm 1.30^{\mathrm{A}, \mathrm{a}}$ \\
\hline & Locust & $19.70 \pm 4.28^{\mathrm{A}, \mathrm{a}}$ & $26.50 \pm 0.69^{\mathrm{A}, \mathrm{a}}$ & $34.52 \pm 1.76^{\mathrm{A}, \mathrm{a}}$ \\
\hline & Silkworm & $28.57 \pm 4.86^{\mathrm{A}, \mathrm{a}}$ & $11.46 \pm 3.19^{\mathrm{B}, \mathrm{b}}$ & $9.42 \pm 6.53^{\mathrm{B}, \mathrm{b}}$ \\
\hline \multirow[t]{3}{*}{11} & Cricket & $36.28 \pm 3.20^{\mathrm{A}, \mathrm{a}}$ & $17.53 \pm 0.61^{\mathrm{A}, \mathrm{a}}$ & $32.18 \pm 0.00^{\mathrm{A}, \mathrm{a}}$ \\
\hline & Locust & $31.12 \pm 3.42^{\mathrm{A}, \mathrm{a}}$ & $31.97 \pm 0.45^{\mathrm{A}, \mathrm{a}}$ & $34.79 \pm 1.14^{\mathrm{A}, \mathrm{a}}$ \\
\hline & Silkwor & $37.24 \pm 8.12^{\mathrm{A}, \mathrm{a}}$ & $22.79 \pm 4.37^{\mathrm{A}, \mathrm{b}}$ & $16.70 \pm 2.33^{\mathrm{A}, \mathrm{b}}$ \\
\hline \multirow[t]{3}{*}{12} & Cricket & $45.53 \pm 4.42^{\mathrm{A}, \mathrm{B}, \mathrm{a}}$ & $26.20 \pm 3.15^{\mathrm{B}, \mathrm{b}}$ & $17.01 \pm 1.44^{\mathrm{B}, \mathrm{c}}$ \\
\hline & Locust & $42.28 \pm 4.68^{\mathrm{B}, \mathrm{a}}$ & $37.68 \pm 5.05^{\mathrm{A}, \mathrm{B}, \mathrm{a}}$ & $45.40 \pm 5.27^{\mathrm{A}, \mathrm{a}}$ \\
\hline & Silkworm & $58.49 \pm 7.80^{\mathrm{A}, \mathrm{a}}$ & $42.94 \pm 1.95^{\mathrm{A}, \mathrm{b}}$ & $19.07 \pm 3.00^{\mathrm{B}, \mathrm{c}}$ \\
\hline
\end{tabular}

$A, B, C$ Different letters indicate significant differences (Student's $t$ test, $\mathrm{P}<0.05$ ) between mean values $( \pm \mathrm{SD}, \mathrm{n}=3$ ) within the same row.

a,b,c Different letters indicate significant differences (Student's t test, $\mathrm{P}<0.05$ ) between mean values $( \pm S D, n=3)$ within the same column

"Initial powder-Brogan et al. 2018 


\section{A. Cricket}
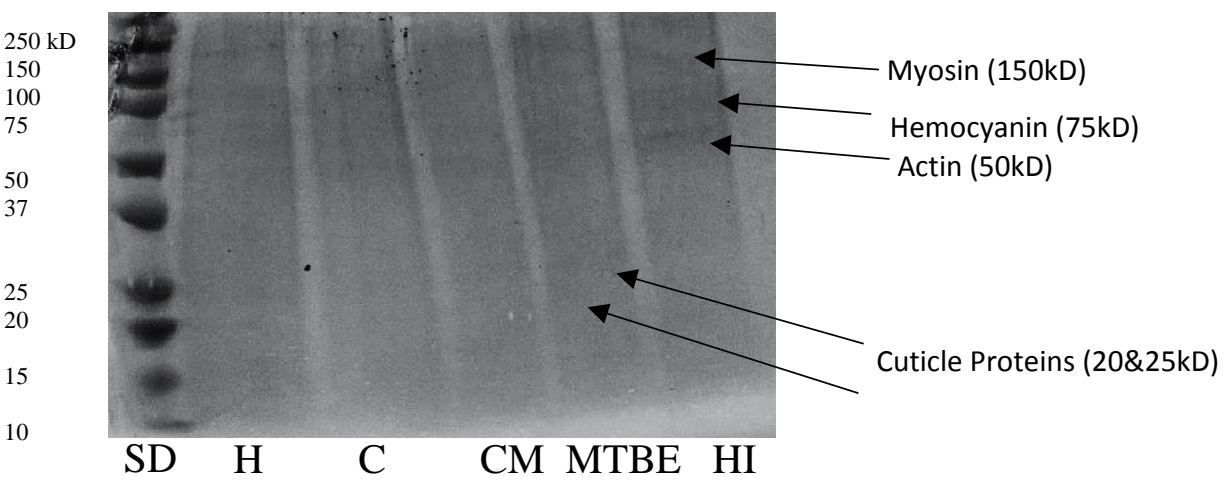

B. Locust

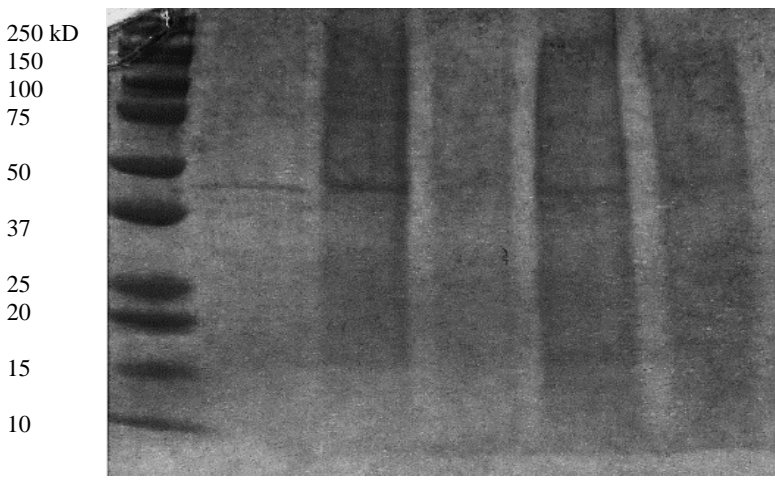
C. Silkworm
C CM MTBE HI

$250 \mathrm{kD}$

150

75

50

37

25

20

15

10

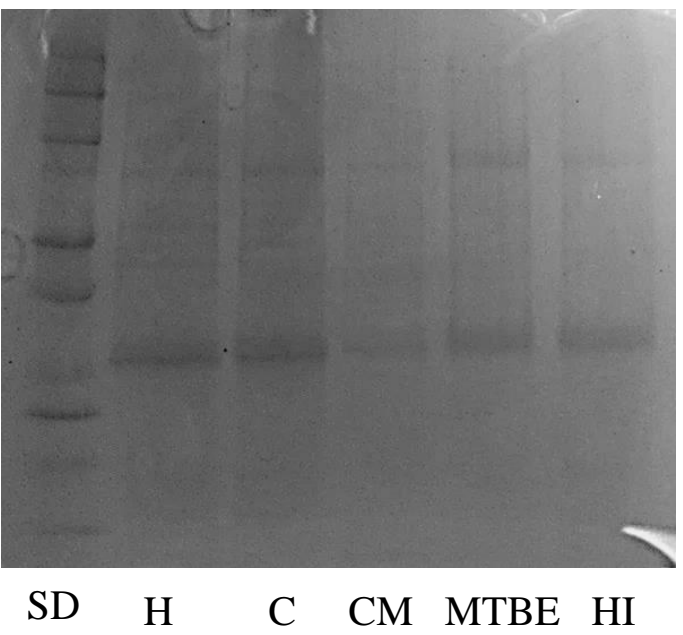

Figure 1. SDS-Page gels of cricket (A), locust (B), and silkworm (C) powders following a onestep organic solvent extraction with various organic solvents. $\mathrm{SD}=$ protein standard, $\mathrm{CM}=$ Chloroform-Methanol, $\quad \mathrm{C}=$ Chloroform, $\quad \mathrm{H}=$ Hexane, $\quad \mathrm{HI}=$ Hexane-Isopropanol, MTBE=Methyl-Tert-Butyl-Ether 
Figure 2: Protein solubility of original and defatted cricket powder in solutions with varying $\mathrm{pH}$

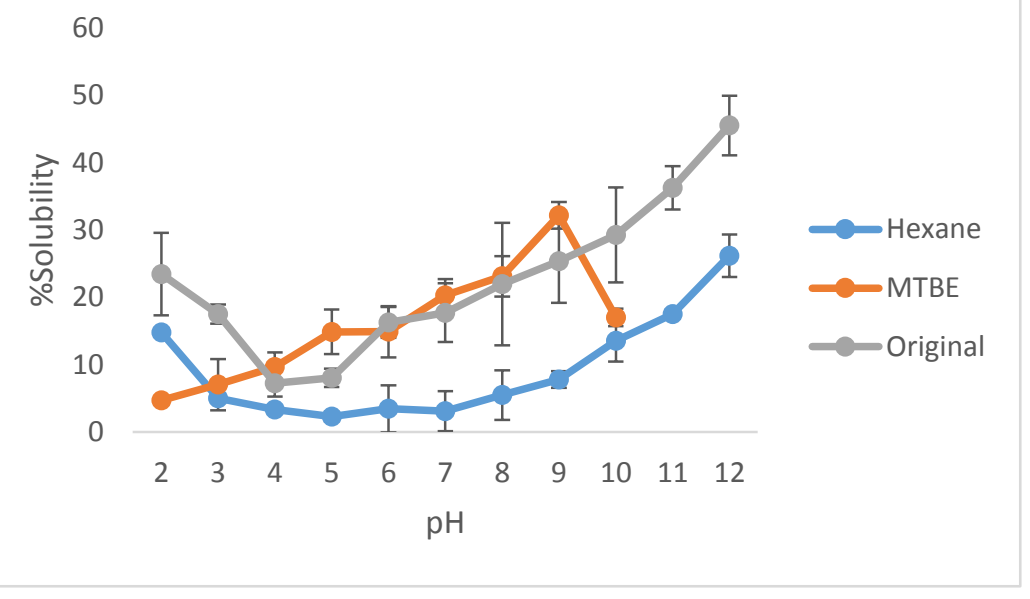

Figure 3: Protein solubility of original and defatted locust powder in solutions with varying $\mathrm{pH}$

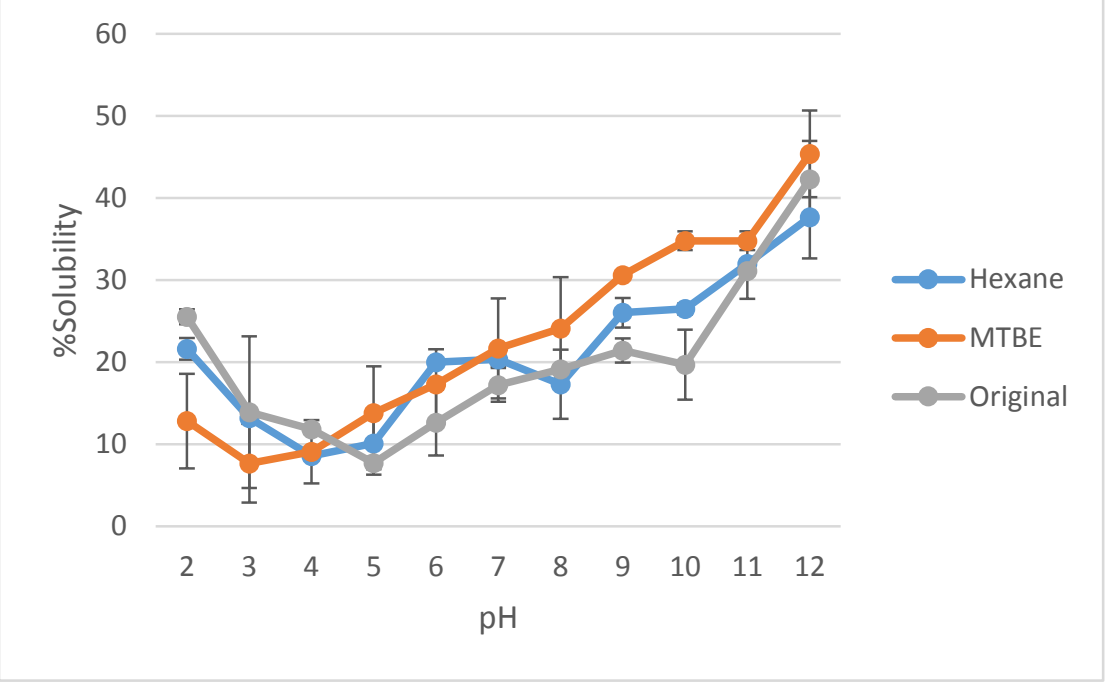

Figure 4: Protein solubility of original and defatted silkworm powder in solutions with varying $\mathrm{pH}$

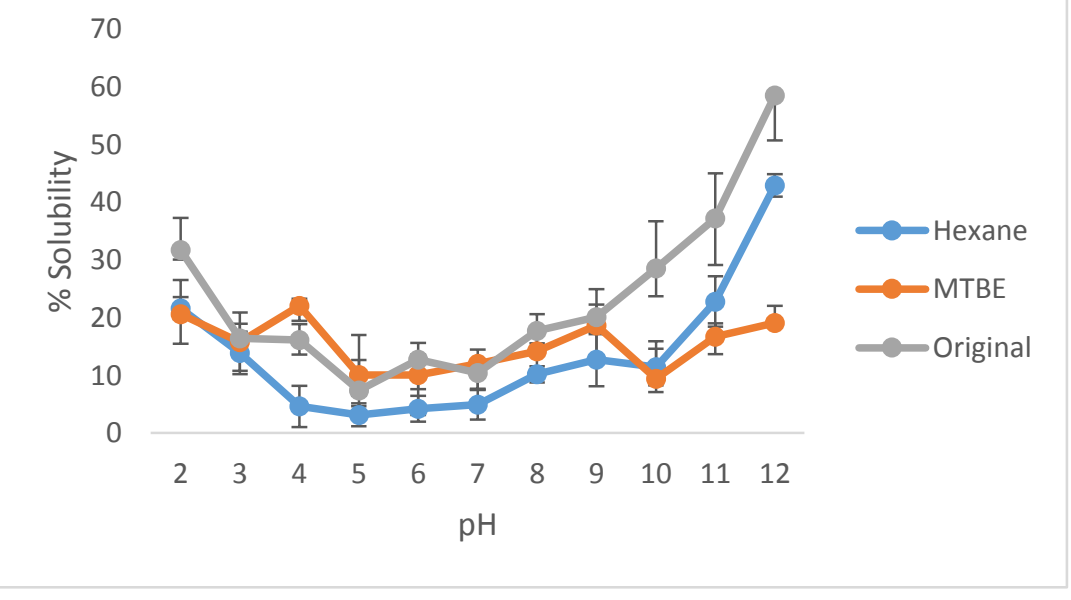




\section{Chapter V}

\section{Appendix}

Figure 1: Protein solubility of original insect powders in various $\mathrm{pH}$ conditions

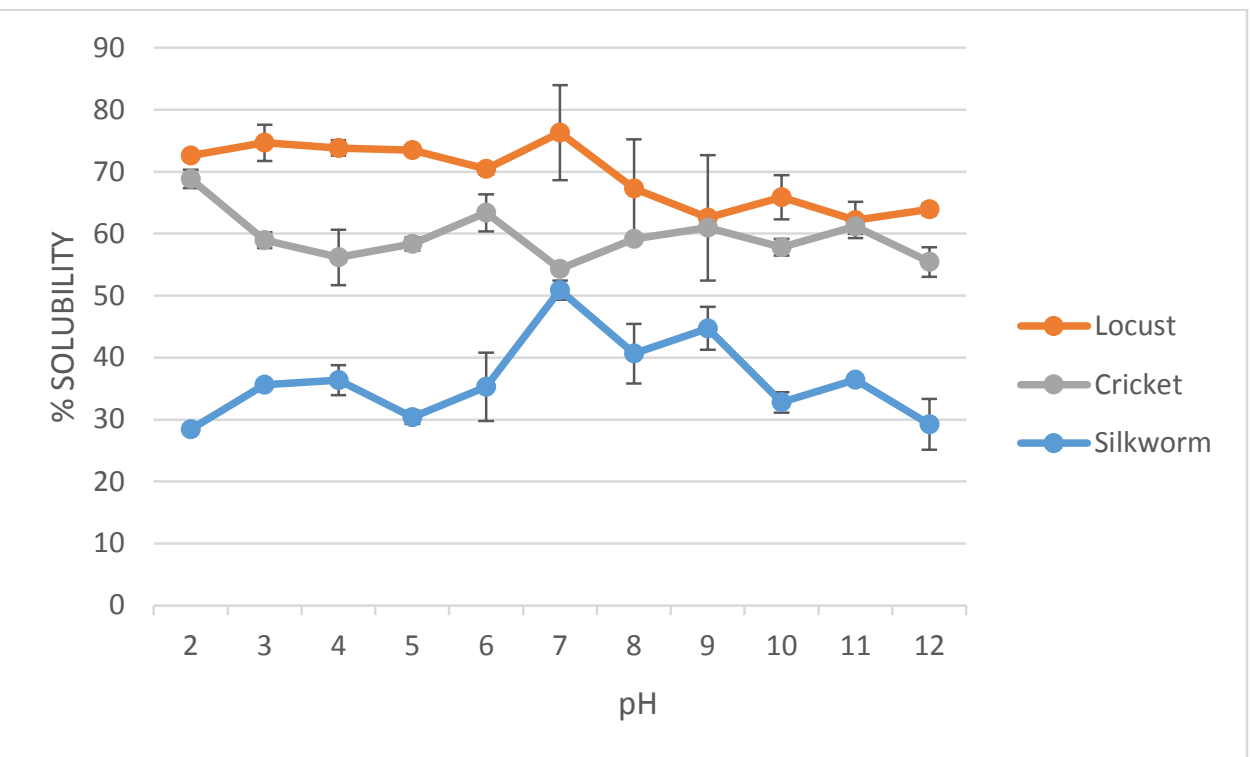

Figure 2: Protein solubility of spent insect powders in various $\mathrm{pH}$ conditions

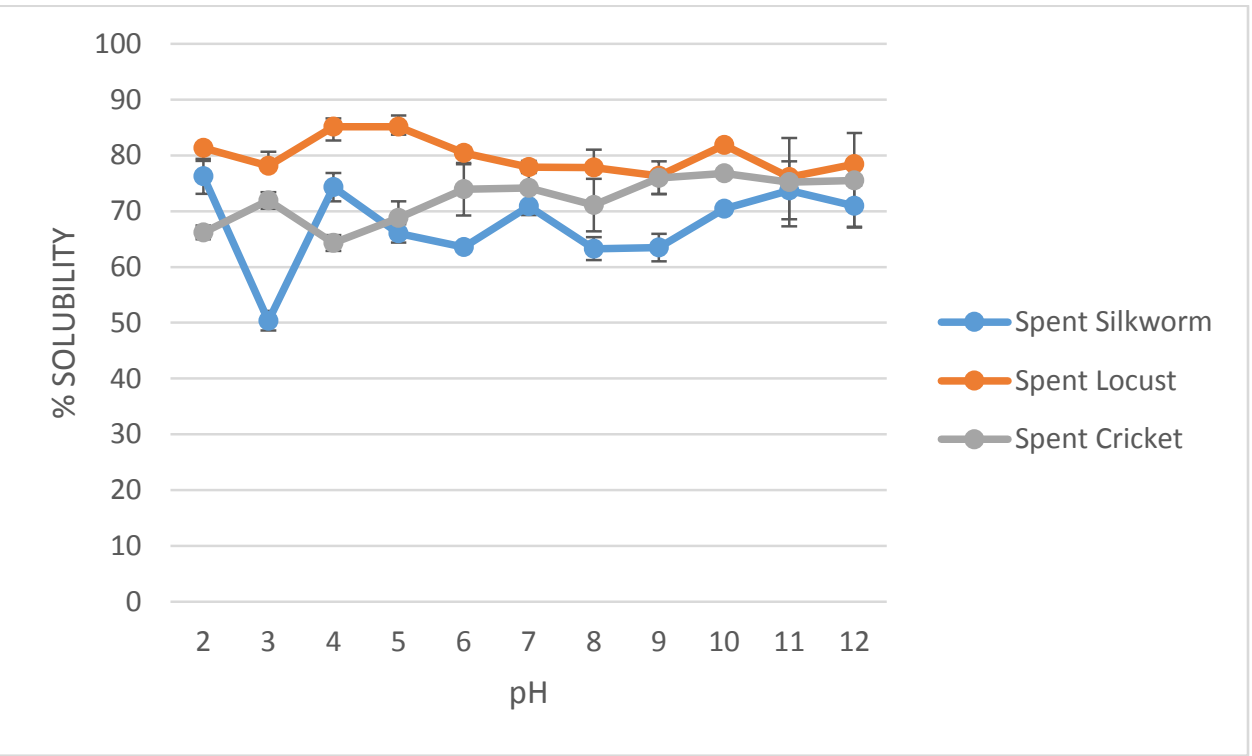




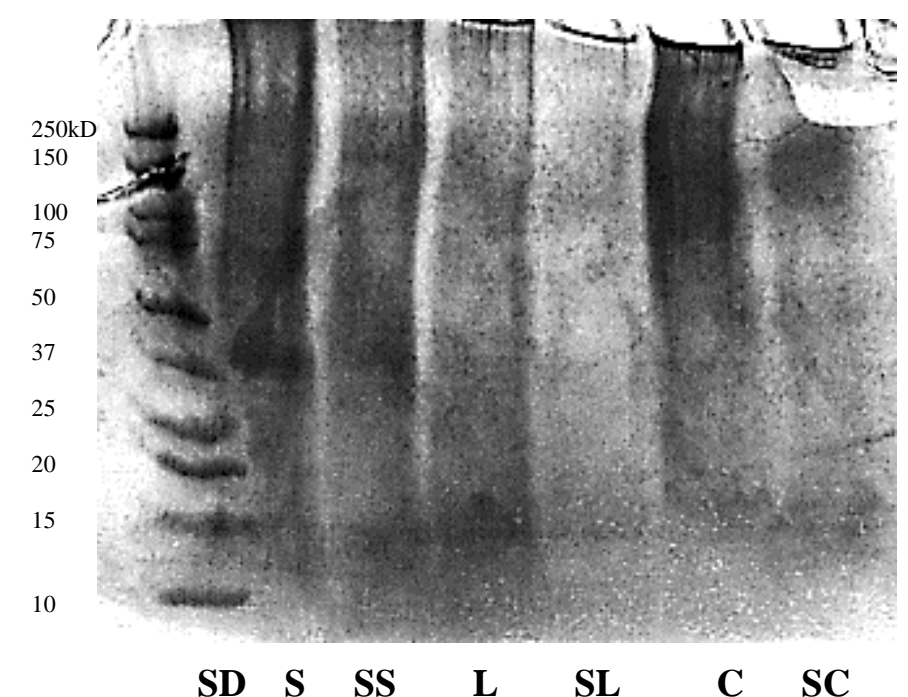

Figure 3. SDS-Page gels of initial insect and spent insect powders following protein solubility.

$\mathrm{SD}=$ standards, $\mathrm{S}=$ silkworm, $\mathrm{L}=$ Locust, $\mathrm{C}=$ cricket, $\mathrm{SS}=$ spent silkworm, $\mathrm{SL}=$ spent locust, $\mathrm{SC}=$ spent cricket 
Table 1: Amino acid composition (g/100g) of spent insect powders following one-step organic solvent extraction with various organic solvents

\begin{tabular}{|c|c|c|c|c|c|c|c|}
\hline Amino Acid & Sample & $\begin{array}{l}\text { Original } \\
\text { Powder }\end{array}$ & Hexane & Chloroform & $\begin{array}{c}\text { Chloroform- } \\
\text { Methanol }\end{array}$ & $\begin{array}{l}\text { Methyl-Tert- } \\
\text { Butyl-Ether }\end{array}$ & $\begin{array}{c}\text { Hexane- } \\
\text { Isopropanol }\end{array}$ \\
\hline \multirow[t]{3}{*}{ Alanine } & Silkworm & $2.46 \pm 0.03^{\mathrm{A}, \mathrm{c}}$ & $13.00 \pm 0.11^{\mathrm{A}, \mathrm{a}}$ & $2.82 \pm 4.90^{\mathrm{A}, \mathrm{c}}$ & $1.77 \pm 3.07^{\mathrm{B}, \mathrm{c}}$ & $8.28 \pm 0.85^{\mathrm{A}, \mathrm{b}}$ & $9.74 \pm 1.19^{\mathrm{A}, \mathrm{b}}$ \\
\hline & Locust & $7.56 \pm 0.07^{\mathrm{A}, \mathrm{b}}$ & $9.56 \pm 4.58^{\mathrm{A}, \mathrm{b}}$ & $20.86 \pm 1.74^{\mathrm{A}, \mathrm{a}}$ & $20.57 \pm 2.59^{\mathrm{A}, \mathrm{a}}$ & $23.19 \pm 1.48^{\mathrm{A}, \mathrm{a}}$ & $5.19 \pm 9.00^{\mathrm{A}, \mathrm{b}}$ \\
\hline & Cricket & $5.89 \pm 0.02^{\mathrm{A}, \mathrm{b}}$ & $14.47 \pm 1.30^{\mathrm{A}, \mathrm{a}}$ & $16.58 \pm 0.73^{\mathrm{A}, \mathrm{a}}$ & $16.98 \pm 0.91^{\mathrm{A}, \mathrm{a}}$ & $15.17 \pm 3.72^{\mathrm{A}, \mathrm{a}}$ & $11.07 \pm 2.16^{\mathrm{A}, \mathrm{a}}$ \\
\hline \multirow[t]{3}{*}{ Glycine } & Silkworm & $2.35 \pm 0.01^{\mathrm{C}, \mathrm{b}}$ & $11.09 \pm 3.32^{\mathrm{A}, \mathrm{a}}$ & $0.00 \pm 0.00^{\mathrm{B}, \mathrm{c}}$ & $1.21 \pm 2.09^{\mathrm{B}, \mathrm{b}}$ & $9.01 \pm 0.20^{\mathrm{A}, \mathrm{a}}$ & $8.35 \pm 0.45^{\mathrm{A}, \mathrm{a}}$ \\
\hline & Locust & $3.94 \pm 0.03^{\mathrm{A}, \mathrm{c}}$ & $7.59 \pm 2.27^{\mathrm{A}, \mathrm{b}}$ & $11.03 \pm 0.50^{\mathrm{A}, \mathrm{a}}$ & $11.70 \pm 1.50^{\mathrm{A}, \mathrm{a}}$ & $1.93 \pm 2.73^{\mathrm{B}, \mathrm{c}}$ & $14.18 \pm 2.78^{\mathrm{A}, \mathrm{a}}$ \\
\hline & Cricket & $3.50 \pm 0.07^{\mathrm{B}, \mathrm{b}}$ & $9.33 \pm 0.87^{\mathrm{A}, \mathrm{a}}$ & $11.34 \pm 2.32^{\mathrm{A}, \mathrm{a}}$ & $10.77 \pm 3.17^{\mathrm{A}, \mathrm{a}}$ & $11.59 \pm 6.25^{\mathrm{A}, \mathrm{a}}$ & $6.88 \pm 1.67^{\mathrm{A}, \mathrm{a}}$ \\
\hline \multirow[t]{3}{*}{ Valine } & Silkworm & $2.13 \pm 0.01^{\mathrm{B}, \mathrm{b}}$ & $10.35 \pm 1.13^{\mathrm{A}, \mathrm{a}}$ & $0.00 \pm 0.00^{\mathrm{B}, \mathrm{c}}$ & $0.00 \pm 0.00^{\mathrm{B}, \mathrm{a}}$ & $8.59 \pm 0.21^{\mathrm{A}, \mathrm{a}}$ & $9.65 \pm 0.91^{\mathrm{A}, \mathrm{a}}$ \\
\hline & Locust & $4.18 \pm 0.03^{\mathrm{A}, \mathrm{b}}$ & $5.48 \pm 0.78^{\mathrm{A}, \mathrm{b}}$ & $7.69 \pm 0.63^{\mathrm{A}, \mathrm{a}}$ & $9.65 \pm 0.26^{\mathrm{A}, \mathrm{a}}$ & $9.26 \pm 0.84^{\mathrm{A}, \mathrm{a}}$ & $9.26 \pm 0.84^{\mathrm{A}, \mathrm{a}}$ \\
\hline & Cricket & $3.84 \pm 0.09^{\mathrm{B}, \mathrm{b}}$ & $9.68 \pm 0.89^{\mathrm{A}, \mathrm{a}}$ & $7.58 \pm 3.04^{\mathrm{A}, \mathrm{a}}$ & $9.96 \pm 0.97^{\mathrm{A}, \mathrm{a}}$ & $10.03 \pm 2.26^{\mathrm{A}, \mathrm{a}}$ & $7.59 \pm 0.35^{\mathrm{A}, \mathrm{a}}$ \\
\hline \multirow[t]{3}{*}{ Leucine } & Silkworm & $3.70 \pm 0.01^{\mathrm{C}, \mathrm{b}}$ & $9.96 \pm 2.20^{\mathrm{A}, \mathrm{a}}$ & $2.50 \pm 3.53^{\mathrm{B}, \mathrm{b}}$ & $0.00 \pm 0.00^{\mathrm{B}, \mathrm{c}}$ & $8.35 \pm 0.77^{\mathrm{A}, \mathrm{a}}$ & $7.67 \pm 1.45^{\mathrm{A}, \mathrm{a}}$ \\
\hline & Locust & $5.04 \pm 0.02^{\mathrm{A}, \mathrm{b}}$ & $9.11 \pm 1.80^{\mathrm{A}, \mathrm{a}}$ & $8.62 \pm 2.14^{\mathrm{A}, \mathrm{a}}$ & $7.85 \pm 0.45^{\mathrm{A}, \mathrm{a}}$ & $8.00 \pm 2.12^{\mathrm{A}, \mathrm{a}}$ & $11.13 \pm 1.71^{\mathrm{A}, \mathrm{a}}$ \\
\hline & Cricket & $4.83 \pm 0.02^{\mathrm{A}, \mathrm{b}}$ & $12.21 \pm 0.57^{\mathrm{A}, \mathrm{a}}$ & $8.19 \pm 2.10^{\mathrm{A}, \mathrm{a}}$ & $8.20 \pm 1.01^{\mathrm{A}, \mathrm{a}}$ & $6.93 \pm 1.72^{\mathrm{A}, \mathrm{a}}$ & $11.39 \pm 0.71^{\mathrm{A}, \mathrm{a}}$ \\
\hline \multirow[t]{3}{*}{ Isoleucine } & Silkworm & $2.35 \pm 0.01^{\mathrm{B}, \mathrm{b}}$ & $6.90 \pm 0.56^{\mathrm{A}, \mathrm{a}}$ & $0.00 \pm 0.00^{\mathrm{B}, \mathrm{c}}$ & $0.00 \pm 0.00^{\mathrm{B}, \mathrm{c}}$ & $8.56 \pm 0.73^{\mathrm{A}, \mathrm{a}}$ & $7.24 \pm 1.39^{\mathrm{A}, \mathrm{a}}$ \\
\hline & Locust & $2.92 \pm 0.01^{\mathrm{A}, \mathrm{b}}$ & $4.44 \pm 0.74^{\mathrm{A}, \mathrm{b}}$ & $9.73 \pm 2.04^{\mathrm{A}, \mathrm{a}}$ & $6.32 \pm 1.34^{\mathrm{A}, \mathrm{a}}$ & $2.16 \pm 3.06^{\mathrm{A}, \mathrm{b}}$ & $8.41 \pm 0.73^{\mathrm{A}, \mathrm{a}}$ \\
\hline & Cricket & $2.91 \pm 0.01^{\mathrm{A}}$ & $7.85 \pm 1.36^{\mathrm{A}, \mathrm{a}}$ & $7.65 \pm 1.90^{\mathrm{A}, \mathrm{a}}$ & $7.78 \pm 0.94^{\mathrm{A}, \mathrm{a}}$ & $6.89 \pm 0.98^{\mathrm{A}, \mathrm{a}}$ & $6.49 \pm 0.84^{\mathrm{A}, \mathrm{a}}$ \\
\hline \multirow[t]{3}{*}{ Threonine } & Silkworm & $2.27 \pm 0.02^{\mathrm{C}, \mathrm{b}}$ & $3.84 \pm 0.56^{\mathrm{A}, \mathrm{b}}$ & $18.01 \pm 4.26^{\mathrm{A}, \mathrm{a}}$ & $0.85 \pm 1.20^{\mathrm{B}, \mathrm{c}}$ & $4.52 \pm 0.26^{\mathrm{A}, \mathrm{b}}$ & $4.41 \pm 0.39^{\mathrm{A}, \mathrm{b}}$ \\
\hline & Locust & $2.33 \pm 0.01^{\mathrm{B}, \mathrm{a}}$ & $3.36 \pm 1.05^{\mathrm{A}, \mathrm{a}}$ & $4.15 \pm 1.10^{\mathrm{B}, \mathrm{a}}$ & $3.23 \pm 0.38^{\mathrm{A}, \mathrm{a}}$ & $4.53 \pm 1.59^{\mathrm{A}, \mathrm{a}}$ & $3.57 \pm 0.59^{\mathrm{A}, \mathrm{a}}$ \\
\hline & Cricket & $2.54 \pm 0.02^{\mathrm{A}, \mathrm{b}}$ & $3.66 \pm 1.07^{\mathrm{A}, \mathrm{a}}$ & $5.25 \pm 1.41^{\mathrm{B}, \mathrm{a}}$ & $4.01 \pm 0.22^{\mathrm{A}, \mathrm{a}}$ & $2.07 \pm 1.85^{\mathrm{A}, \mathrm{b}}$ & $2.13 \pm 0.70^{\mathrm{A}, \mathrm{b}}$ \\
\hline \multirow[t]{3}{*}{ Serine } & Silkworm & $1.98 \pm 0.02^{\mathrm{C}, \mathrm{c}}$ & $2.39 \pm 0.18^{\mathrm{A}, \mathrm{b}}$ & $20.12 \pm 2.56^{\mathrm{A}, \mathrm{a}}$ & $1.22 \pm 1.72^{\mathrm{A}, \mathrm{c}}$ & $4.63 \pm 0.54^{\mathrm{A}, \mathrm{b}}$ & $3.60 \pm 0.47^{\mathrm{A}, \mathrm{b}}$ \\
\hline & Locust & $2.22 \pm 0.01^{\mathrm{B}, \mathrm{c}}$ & $7.01 \pm 1.54^{\mathrm{A}, \mathrm{a}}$ & $6.54 \pm 0.28^{\mathrm{B}, \mathrm{a}}$ & $3.39 \pm 0.25^{\mathrm{A}, \mathrm{b}}$ & $6.10 \pm 0.20^{\mathrm{A}, \mathrm{a}}$ & $2.50 \pm 1.02^{\mathrm{A}, \mathrm{c}}$ \\
\hline & Cricket & $2.87 \pm 0.06^{\mathrm{A}, \mathrm{b}}$ & $4.34 \pm 1.60^{\mathrm{A}, \mathrm{a}}$ & $6.48 \pm 2.00^{\mathrm{B}, \mathrm{a}}$ & $4.90 \pm 0.32^{\mathrm{A}, \mathrm{a}}$ & $5.80 \pm 2.87^{\mathrm{A}, \mathrm{a}}$ & $2.30 \pm 1.12^{\mathrm{A}, \mathrm{b}}$ \\
\hline \multirow[t]{3}{*}{ Proline } & Silkworm & $1.96 \pm 0.03^{\mathrm{C}, \mathrm{b}}$ & $7.94 \pm 1.63^{\mathrm{A}, \mathrm{a}}$ & $0.00 \pm 0.00^{\mathrm{B}, \mathrm{c}}$ & $0.00 \pm 0.00^{\mathrm{B}, \mathrm{c}}$ & $6.40 \pm 0.18^{\mathrm{A}, \mathrm{a}}$ & $6.65 \pm 0.00^{\mathrm{A}, \mathrm{a}}$ \\
\hline & Locust & $4.31 \pm 0.04^{\mathrm{A}, \mathrm{b}}$ & $5.58 \pm 0.29^{\mathrm{A}, \mathrm{b}}$ & $8.22 \pm 0.87^{\mathrm{A}, \mathrm{a}}$ & $8.83 \pm 0.24^{\mathrm{A}, \mathrm{a}}$ & $11.11 \pm 0.80^{\mathrm{A}, \mathrm{a}}$ & $14.20 \pm 0.67^{\mathrm{A}, \mathrm{a}}$ \\
\hline & Cricket & $3.54 \pm 0.04^{\mathrm{B}, \mathrm{c}}$ & $8.60 \pm 1.05^{\mathrm{A}, \mathrm{a}}$ & $7.09 \pm 0.68^{\mathrm{A}, \mathrm{a}}$ & $8.62 \pm 0.98^{\mathrm{A}, \mathrm{a}}$ & $8.97 \pm 0.28^{\mathrm{A}, \mathrm{a}}$ & $5.69 \pm 1.06^{\mathrm{A}, \mathrm{b}}$ \\
\hline \multirow[t]{3}{*}{ Aspartic Acid } & Silkworm & $5.22 \pm 0.05^{\mathrm{B}, \mathrm{b}}$ & $8.09 \pm 0.96^{\mathrm{A}, \mathrm{a}}$ & $0.00 \pm 0.00^{\mathrm{B}, \mathrm{c}}$ & $0.00 \pm 0.00^{\mathrm{B}, \mathrm{c}}$ & $9.83 \pm 0.39^{\mathrm{A}, \mathrm{a}}$ & $8.94 \pm 1.00^{\mathrm{A}, \mathrm{a}}$ \\
\hline & Locust & $4.74 \pm 0.02^{\mathrm{C}, \mathrm{b}}$ & $4.43 \pm 1.28^{\mathrm{A}, \mathrm{b}}$ & $5.26 \pm 0.84^{\mathrm{A}, \mathrm{a}, \mathrm{b}}$ & $6.04 \pm 0.33^{\mathrm{A}, \mathrm{a}}$ & $4.63 \pm 1.27^{\mathrm{A}, \mathrm{b}}$ & $6.85 \pm 1.00^{\mathrm{A}, \mathrm{a}}$ \\
\hline & Cricket & $5.66 \pm 0.03^{\mathrm{A}, \mathrm{b}}$ & $8.23 \pm 0.96^{\mathrm{A}, \mathrm{a}}$ & $7.99 \pm 0.95^{\mathrm{A}, \mathrm{a}}$ & $8.44 \pm 1.57^{\mathrm{A}, \mathrm{a}}$ & $8.27 \pm 2.07^{\mathrm{A}, \mathrm{a}}$ & $6.31 \pm 0.44^{\mathrm{A}, \mathrm{a}, \mathrm{b}}$ \\
\hline Glutamic & Silkworm & $4.99 \pm 0.07^{\mathrm{C}, \mathrm{b}}$ & $8.06 \pm 0.23^{\mathrm{A}, \mathrm{a}}$ & $0.00 \pm 0.00^{\mathrm{B}, \mathrm{c}}$ & $0.00 \pm 0.00^{\mathrm{B}, \mathrm{c}}$ & $10.12 \pm 0.17^{\mathrm{A}, \mathrm{a}}$ & $9.33 \pm 0.60^{\mathrm{A}, \mathrm{a}}$ \\
\hline Acid & Locust & $6.20 \pm 0.03^{\mathrm{B}, \mathrm{b}}$ & $6.01 \pm 1.68^{\mathrm{A}, \mathrm{b}}$ & $9.78 \pm 1.98^{\mathrm{A}, \mathrm{a}}$ & $9.78 \pm 1.98^{\mathrm{A}, \mathrm{a}}$ & $6.52 \pm 0.78^{\mathrm{A}, \mathrm{b}}$ & $8.55 \pm 0.28^{\mathrm{A}, \mathrm{a}}$ \\
\hline
\end{tabular}




\begin{tabular}{|c|c|c|c|c|c|c|c|}
\hline \multirow{3}{*}{ Phenylalanine } & Cricket & $6.48 \pm 0.03^{\mathrm{A}, \mathrm{b}}$ & $12.34 \pm 0.74^{\mathrm{A}, \mathrm{a}}$ & $8.13 \pm 1.33^{\mathrm{A}, \mathrm{b}}$ & $10.00 \pm 1.32^{\mathrm{A}, \mathrm{a}}$ & $0.00 \pm 0.00^{\mathrm{B}, \mathrm{c}}$ & $17.23 \pm 1.26^{\mathrm{A}, \mathrm{a}}$ \\
\hline & Silkworm & $2.68 \pm 0.06^{\mathrm{A}, \mathrm{b}}$ & $8.21 \pm 0.18^{\mathrm{A}, \mathrm{a}}$ & $0.00 \pm 0.00^{\mathrm{A}, \mathrm{c}}$ & $0.00 \pm 0.00^{\mathrm{B}, \mathrm{c}}$ & $5.69 \pm 0.79^{\mathrm{A}, \mathrm{a}}$ & $6.05 \pm 0.63^{\mathrm{A}, \mathrm{a}}$ \\
\hline & Locust & $2.03 \pm 0.01^{\mathrm{C}, \mathrm{b}}$ & $4.81 \pm 1.64^{\mathrm{A}, \mathrm{a}}$ & $3.90 \pm 1.12^{\mathrm{A}, \mathrm{a}}$ & $2.53 \pm 0.33^{\mathrm{A}, \mathrm{b}}$ & $3.15 \pm 1.42^{\mathrm{A}, \mathrm{a}, \mathrm{b}}$ & $4.40 \pm 0.99^{\mathrm{A}, \mathrm{a}}$ \\
\hline \multirow{4}{*}{ Lysine } & Cricket & $2.34 \pm 0.02^{\mathrm{B}, \mathrm{b}}$ & $6.18 \pm 0.95^{\mathrm{A}, \mathrm{a}}$ & $3.85 \pm 1.07^{\mathrm{A}, \mathrm{b}}$ & $3.31 \pm 0.27^{\mathrm{A}, \mathrm{b}}$ & $4.30 \pm 0.16^{\mathrm{A}, \mathrm{a}}$ & $7.74 \pm 0.29^{\mathrm{A}, \mathrm{a}}$ \\
\hline & Silkworm & $3.68 \pm 0.04^{\mathrm{B}, \mathrm{b}}$ & $3.96 \pm 0.71^{\mathrm{A}, \mathrm{b}}$ & $6.04 \pm 0.00^{\mathrm{A}, \mathrm{a}}$ & $0.00 \pm 0.00^{\mathrm{B}, \mathrm{c}}$ & $4.48 \pm 0.29^{\mathrm{A}, \mathrm{a}, \mathrm{b}}$ & $4.40 \pm 0.95^{\mathrm{A}, \mathrm{a}, \mathrm{b}}$ \\
\hline & Locust & $3.64 \pm 0.02^{\mathrm{B}, \mathrm{b}}$ & $5.15 \pm 1.14^{\mathrm{A}, \mathrm{a}}$ & $3.50 \pm 0.54^{\mathrm{A}, \mathrm{b}}$ & $3.46 \pm 0.56^{\mathrm{A}, \mathrm{b}}$ & $2.92 \pm 0.22^{\mathrm{A}, \mathrm{b}}$ & $3.62 \pm 0.00^{\mathrm{A}, \mathrm{b}}$ \\
\hline & Cricket & $3.90 \pm 0.03^{\mathrm{A}, \mathrm{a}}$ & $3.82 \pm 0.00^{\mathrm{A}, \mathrm{a}}$ & $2.64 \pm 0.43^{\mathrm{A}, \mathrm{a}, \mathrm{b}}$ & $4.16 \pm 0.28^{\mathrm{A}, \mathrm{a}}$ & $2.40 \pm 0.38^{\mathrm{A}, \mathrm{a}, \mathrm{b}}$ & $4.25 \pm 0.15^{\mathrm{A}, \mathrm{a}}$ \\
\hline \multirow[t]{3}{*}{ Histidine } & Silkworm & $1.69 \pm 0.03^{\mathrm{B}, \mathrm{c}}$ & $2.46 \pm 0.24^{\mathrm{A}, \mathrm{c}}$ & $20.29 \pm 0.87^{\mathrm{A}, \mathrm{a}}$ & $1.00 \pm 1.74^{\mathrm{A}, \mathrm{c}}$ & $7.96 \pm 0.50^{\mathrm{A}, \mathrm{b}}$ & $6.15 \pm 0.33^{\mathrm{A}, \mathrm{b}}$ \\
\hline & Locust & $1.56 \pm 0.00^{\mathrm{A}, \mathrm{b}}$ & $2.14 \pm 1.97^{\mathrm{A}, \mathrm{b}}$ & $0.93 \pm 1.05^{\mathrm{B}, \mathrm{b}}$ & $4.72 \pm 0.55^{\mathrm{A}, \mathrm{a}}$ & $2.07 \pm 0.95^{\mathrm{A}, \mathrm{b}}$ & $1.88 \pm 0.88^{\mathrm{B}, \mathrm{b}}$ \\
\hline & Cricket & $1.52 \pm 0.05^{\mathrm{A}, \mathrm{b}}$ & $3.35 \pm 1.53^{\mathrm{A}, \mathrm{a}}$ & $1.26 \pm 1.21^{\mathrm{B}, \mathrm{b}}$ & $4.41 \pm 0.30^{\mathrm{A}, \mathrm{a}}$ & $0.32 \pm 0.28^{\mathrm{B}, \mathrm{c}}$ & $1.99 \pm 0.43^{\mathrm{B}, \mathrm{b}}$ \\
\hline \multirow[t]{3}{*}{ Tyrosine } & Silkworm & $3.19 \pm 0.04^{\mathrm{B}, \mathrm{b}}$ & $6.26 \pm 1.69^{\mathrm{A}, \mathrm{b}}$ & $16.83 \pm 0.46^{\mathrm{A}, \mathrm{a}}$ & $0.00 \pm 0.00^{\mathrm{B}, \mathrm{c}}$ & $4.28 \pm 0.52^{\mathrm{A}, \mathrm{b}}$ & $4.57 \pm 1.22^{\mathrm{A}, \mathrm{b}}$ \\
\hline & Locust & $4.18 \pm 0.03^{\mathrm{A}, \mathrm{a}}$ & $4.73 \pm 0.91^{\mathrm{A}, \mathrm{a}}$ & $4.19 \pm 0.77^{\mathrm{B}, \mathrm{a}}$ & $3.25 \pm 0.50^{\mathrm{A}, \mathrm{a}}$ & $3.56 \pm 1.83^{\mathrm{A}, \mathrm{a}}$ & $4.28 \pm 0.62^{\mathrm{A}, \mathrm{a}}$ \\
\hline & Cricket & $3.84 \pm 0.09^{\mathrm{B}, \mathrm{a}}$ & $4.44 \pm 1.35^{\mathrm{A}, \mathrm{a}}$ & $2.94 \pm 0.59^{\mathrm{B}, \mathrm{a}}$ & $3.28 \pm 0.29^{\mathrm{A}, \mathrm{a}}$ & $1.72 \pm 2.43^{\mathrm{A}, \mathrm{b}}$ & $4.97 \pm 1.22^{\mathrm{A}, \mathrm{a}}$ \\
\hline \multirow[t]{3}{*}{ Methionine } & Silkworm & $1.49 \pm 0.02^{\mathrm{A}, \mathrm{b}}$ & $0.62 \pm 0.02^{\mathrm{A}, \mathrm{c}, \mathrm{d}}$ & $2.20 \pm 0.00^{\mathrm{A}, \mathrm{a}}$ & $0.41 \pm 0.02^{\mathrm{A}, \mathrm{c}, \mathrm{d}}$ & $0.64 \pm 0.69^{\mathrm{A}, \mathrm{c}}$ & $0.00 \pm 0.00^{\mathrm{A}, \mathrm{d}}$ \\
\hline & Locust & $0.90 \pm 0.00^{\mathrm{C}, \mathrm{a}}$ & $0.00 \pm 0.00^{\mathrm{B}, \mathrm{e}}$ & $0.22 \pm 0.29^{\mathrm{B}, \mathrm{c}}$ & $0.10 \pm 0.02^{\mathrm{C}, \mathrm{d}}$ & $0.19 \pm 0.04^{\mathrm{A}, \mathrm{c}}$ & $0.29 \pm 0.03^{\mathrm{A}, \mathrm{b}}$ \\
\hline & Cricket & $1.10 \pm 0.01^{\mathrm{B}, \mathrm{a}}$ & $0.19 \pm 0.6^{\mathrm{B}, \mathrm{b}}$ & $0.22 \pm 0.06^{\mathrm{B}, \mathrm{b}}$ & $0.24 \pm 0.08^{\mathrm{B}, \mathrm{b}}$ & $0.24 \pm 0.08^{\mathrm{A}, \mathrm{b}}$ & $0.29 \pm 0.05^{\mathrm{A}, \mathrm{b}}$ \\
\hline \multirow[t]{3}{*}{ Tryptophan } & Silkworm & $0.90 \pm 0.02^{\mathrm{A}, \mathrm{a}}$ & $0.02 \pm 0.01^{\mathrm{A}, \mathrm{b}}$ & $0.02 \pm 0.02^{\mathrm{A}, \mathrm{b}}$ & $0.00 \pm 0.00^{\mathrm{A}, \mathrm{b}}$ & $0.02 \pm 0.03^{\mathrm{A}, \mathrm{b}}$ & $0.00 \pm 0.00^{\mathrm{A}, \mathrm{b}}$ \\
\hline & Locust & $0.52 \pm 0.02^{\mathrm{C}, \mathrm{a}}$ & $0.00 \pm 0.00^{\mathrm{B}, \mathrm{b}}$ & $0.00 \pm 0.00^{\mathrm{A}, \mathrm{b}}$ & $0.00 \pm 0.00^{\mathrm{A}, \mathrm{b}}$ & $0.00 \pm 0.00^{\mathrm{A}, \mathrm{b}}$ & $0.00 \pm 0.00^{\mathrm{A}, \mathrm{b}}$ \\
\hline & Cricket & $0.68 \pm 0.02^{\mathrm{B}, \mathrm{a}}$ & $0.00 \pm 0.00^{\mathrm{B}, \mathrm{b}}$ & $0.68 \pm 0.00^{\mathrm{A}, \mathrm{b}}$ & $0.00 \pm 0.00^{\mathrm{A}, \mathrm{b}}$ & $0.00 \pm 0.00^{\mathrm{A}, \mathrm{b}}$ & $0.00 \pm 0.00^{\mathrm{A}, \mathrm{b}}$ \\
\hline
\end{tabular}

$\overline{\mathrm{A}, \mathrm{B}, \mathrm{C}}$ Different letters indicate significant differences (Student's t test, $\mathrm{P}<0.05)$ between mean values $( \pm \mathrm{SD}, \mathrm{n}=3)$ within the column. a,b,c Different letters indicate significant differences (Student's t test, $\mathrm{P}<0.05)$ between mean values $( \pm \mathrm{SD}$, $\mathrm{n}=3$ ) within the same row. Initial lipid- Brogan et al., 2018 
Table 2: Protein Solubility (\%) of original insect and spent insect powders

\begin{tabular}{|c|c|c|c|c|c|c|}
\hline pH & Silkworm & Spent Silkworm & Locust & Spent Locust & Cricket & Spent Cricket \\
\hline 2 & $28.44 \pm 0.64^{\mathrm{E}, \mathrm{f}}$ & $76.26 \pm 3.17^{\mathrm{B}, \mathrm{a}}$ & $72.61 \pm 0.09^{\mathrm{B}, \mathrm{C}, \mathrm{a}, \mathrm{b}, \mathrm{c}}$ & $81.34 \pm 1.22^{\mathrm{A}, \mathrm{a}}$ & $68.84 \pm 1.48^{\mathrm{C}, \mathrm{D}, \mathrm{a}}$ & $66.20 \pm 2.31^{\mathrm{D}, \mathrm{e}, \mathrm{f}}$ \\
\hline 3 & $35.65 \pm 0.65^{\mathrm{E}, \mathrm{c}, \mathrm{d}, \mathrm{e}}$ & $50.35 \pm 1.76^{\mathrm{D}, \mathrm{e}}$ & $74.67 \pm 2.91^{\mathrm{A}, \mathrm{B}, \mathrm{a}}$ & $78.15 \pm 1.47^{\mathrm{A}, \mathrm{a}}$ & $58.93 \pm 1.28^{\mathrm{C}, \mathrm{D}, \mathrm{c}, \mathrm{d}}$ & $71.92 \pm 0.00^{\mathrm{B}, \mathrm{C}, \mathrm{b}, \mathrm{c}, \mathrm{d}}$ \\
\hline 4 & $36.35 \pm 2.44^{\mathrm{E}, \mathrm{c}, \mathrm{d}}$ & $74.30 \pm 2.54^{\mathrm{B}, \mathrm{a}, \mathrm{b}}$ & $73.85 \pm 1.26^{\mathrm{B}, \mathrm{a}, \mathrm{b}}$ & $85.14 \pm 1.42^{\mathrm{A}, \mathrm{a}}$ & $56.18 \pm 4.49^{\mathrm{D}, \mathrm{d}, \mathrm{e}}$ & $64.29 \pm 2.48^{\mathrm{C}, \mathrm{f}}$ \\
\hline 6 & $35.27 \pm 5.53^{\mathrm{D}, \mathrm{c}, \mathrm{d}, \mathrm{e}}$ & $63.55 \pm 0.46^{\mathrm{C}, \mathrm{d}}$ & $70.45 \pm 0.85^{\mathrm{B}, \mathrm{C}, \mathrm{a}, \mathrm{b}, \mathrm{c}}$ & $80.47 \pm 4.71^{\mathrm{A}, \mathrm{a}}$ & $63.38 \pm 3.00^{\mathrm{C}, \mathrm{b}}$ & $73.95 \pm 2.03^{\mathrm{A}, \mathrm{B}, \mathrm{a}, \mathrm{b}, \mathrm{c}}$ \\
\hline 7 & $50.88 \pm 1.53^{\mathrm{B}, \mathrm{a}}$ & $70.85 \pm 0.34^{\mathrm{A}, \mathrm{a}, \mathrm{b}, \mathrm{c}}$ & $76.29 \pm 7.67^{\mathrm{A}, \mathrm{a}}$ & $77.89 \pm 4.87^{\mathrm{A}, \mathrm{a}}$ & $54.31 \pm 0.28^{\mathrm{B}, \mathrm{e}}$ & $74.14 \pm 1.01^{\mathrm{A}, \mathrm{a}, \mathrm{b}, \mathrm{c}}$ \\
\hline 8 & $40.64 \pm 4.81^{\mathrm{D}, \mathrm{b}, \mathrm{c}}$ & $63.28 \pm 2.08^{\mathrm{B}, \mathrm{C}, \mathrm{d}}$ & $67.28 \pm 7.96^{\mathrm{A}, \mathrm{B}, \mathrm{C}, \mathrm{a}, \mathrm{b}, \mathrm{c}}$ & $77.80 \pm 4.70^{\mathrm{A}, \mathrm{a}}$ & $59.18 \pm 0.02^{\mathrm{C}, \mathrm{b}, \mathrm{c}, \mathrm{d}}$ & $71.11 \pm 0.31^{\mathrm{A}, \mathrm{B}, \mathrm{c}, \mathrm{d}}$ \\
\hline 10 & $32.77 \pm 1.64^{\mathrm{F}, \mathrm{d}, \mathrm{e}, \mathrm{f}}$ & $70.43 \pm 0.36^{\mathrm{C}, \mathrm{b}, \mathrm{c}}$ & $65.89 \pm 3.58^{\mathrm{D}, \mathrm{a}, \mathrm{b}, \mathrm{c}}$ & $81.86 \pm 0.76^{\mathrm{A}, \mathrm{a}}$ & $57.80 \pm 1.35^{\mathrm{E}, \mathrm{c}, \mathrm{d}, \mathrm{e}}$ & $76.76 \pm 0.57^{\mathrm{B}, \mathrm{a}}$ \\
\hline 11 & $36.44 \pm 0.39^{\mathrm{C}, \mathrm{c}, \mathrm{d}}$ & $73.72 \pm 5.19^{\mathrm{A}, \mathrm{a}, \mathrm{b}}$ & $62.21 \pm 2.95^{\mathrm{B}, \mathrm{c}}$ & $76.11 \pm 7.91^{\mathrm{A}, \mathrm{a}}$ & $61.19 \pm 1.24^{\mathrm{B}, \mathrm{b}, \mathrm{c}}$ & $75.20 \pm 0.18^{\mathrm{A}, \mathrm{a}, \mathrm{b}}$ \\
\hline 12 & $29.24 \pm 4.09^{\mathrm{D}, \mathrm{e}, \mathrm{f}}$ & $70.92 \pm 3.72^{\mathrm{A}, \mathrm{B}, \mathrm{a}, \mathrm{b}, \mathrm{c}}$ & $63.93 \pm 0.94^{\mathrm{B}, \mathrm{C}, \mathrm{b}, \mathrm{c}}$ & $78.42 \pm 8.47^{\mathrm{A}, \mathrm{a}}$ & $55.43 \pm 2.41^{\mathrm{C}, \mathrm{d}, \mathrm{e}}$ & $75.52 \pm 0.53^{\mathrm{A}, \mathrm{a}, \mathrm{b}}$ \\
\hline
\end{tabular}

$\overline{\mathrm{A}, \mathrm{B}, \mathrm{C}}$ Different letters indicate significant differences (Student's t test, $\mathrm{P}<0.05)$ between mean values $( \pm \mathrm{SD}, \mathrm{n}=2)$ within the same row.

a,b,c Different letters indicate significant differences (Student's t test, $\mathrm{P}<0.05$ ) between mean values $( \pm \mathrm{SD}$, $\mathrm{n}=2)$ within the same column. 
Table 3: Proximate composition (g/100g, dry basis) of original and spent insect powders following protein solubility

\begin{tabular}{|c|c|c|c|c|c|c|}
\hline Proximate & $\begin{array}{c}\text { Silkworm } \\
\text { pH } 7\end{array}$ & $\begin{array}{c}\text { Spent } \\
\text { Silkworm } \\
\text { pH } 2\end{array}$ & $\begin{array}{c}\text { Locust } \\
\text { pH } 7\end{array}$ & $\begin{array}{c}\text { Spent } \\
\text { Locust } \\
\text { pH } 5\end{array}$ & $\begin{array}{c}\text { Cricket } \\
\text { pH } 2\end{array}$ & $\begin{array}{c}\text { Spent } \\
\text { Cricket } \\
\text { pH } 10\end{array}$ \\
\hline Moisture & $9.94 \pm 0.43^{\mathrm{a}}$ & $14.77 \pm 0.33^{a}$ & $15.75 \pm 4.04^{\mathrm{a}}$ & $14.05 \pm 3.01^{\mathrm{a}}$ & $16.15 \pm 3.02^{\mathrm{a}}$ & $14.82 \pm 2.19^{a}$ \\
\hline Ash & $9.53 \pm 3.12^{b}$ & $13.92 \pm 8.15^{\mathrm{a}, \mathrm{b}}$ & $8.62 \pm 0.97^{b}$ & $11.31 \pm 5.16^{b}$ & $15.37 \pm 7.04^{\mathrm{a}, \mathrm{b}}$ & $25.81 \pm 2.84^{\mathrm{a}}$ \\
\hline $\begin{array}{l}\text { Crude } \\
\text { Protein }\end{array}$ & $55.61 \pm 1.44^{c}$ & $57.61 \pm 1.08^{c}$ & $86.81 \pm 0.76^{a}$ & $86.23 \pm 1.49^{\mathrm{a}}$ & $57.27 \pm 0.39^{c}$ & $66.33 \pm 0.32^{b}$ \\
\hline $\begin{array}{l}\text { Crude } \\
\text { Lipid }\end{array}$ & $31.63 \pm 0.00^{\mathrm{a}}$ & $1.23 \pm 1.81^{\mathrm{b}, \mathrm{c}}$ & $2.30 \pm 1.51^{b, c}$ & $0.00 \pm 0.52^{c}$ & $5.62 \pm 2.97^{\mathrm{b}}$ & $0.30 \pm 1.91^{\mathrm{c}}$ \\
\hline
\end{tabular}

Table 4: Amino acid composition $(\mathrm{g} / 100 \mathrm{~g})$ of original and spent insect powders following protein solubility

\begin{tabular}{|c|c|c|c|c|c|c|}
\hline Amino Acid & $\begin{array}{c}\text { Silkworm } \\
\text { pH } 7\end{array}$ & $\begin{array}{c}\text { Spent } \\
\text { Silkworm } \\
\text { pH } 2 \\
\end{array}$ & $\begin{array}{c}\text { Locust } \\
\text { pH } 7\end{array}$ & $\begin{array}{c}\text { Spent } \\
\text { Locust } \\
\text { pH } 5\end{array}$ & $\begin{array}{c}\text { Cricket } \\
\text { pH } 2\end{array}$ & $\begin{array}{c}\text { Spent Cricket } \\
\text { pH } 10\end{array}$ \\
\hline Alanine & $12.57 \pm 1.21^{\mathrm{b}}$ & $0.00 \pm 0.00^{\mathrm{c}}$ & $19.08 \pm 7.99^{b}$ & $20.49 \pm 0.16^{\mathrm{a}}$ & $0.00 \pm 0.00^{c}$ & $0.00 \pm 0.00^{\mathrm{c}}$ \\
\hline Glycine & $10.24 \pm 0.80^{\mathrm{a}}$ & $0.00 \pm 0.00^{c}$ & $2.14 \pm 0.00^{\mathrm{b}}$ & $10.91 \pm 0.79^{a}$ & $0.00 \pm 0.00^{c}$ & $0.00 \pm 0.00^{\mathrm{c}}$ \\
\hline Valine & $10.97 \pm 1.81^{\mathrm{a}}$ & $3.31 \pm 5.73^{\mathrm{b}}$ & $13.15 \pm 0.14^{\mathrm{a}}$ & $11.14 \pm 0.54^{\mathrm{a}}$ & $2.63 \pm 4.56^{\mathrm{b}}$ & $0.00 \pm 0.00^{\mathrm{c}}$ \\
\hline Isoleucine & $6.82 \pm 0.83^{\mathrm{a}}$ & $0.00 \pm 0.00^{\mathrm{b}}$ & $0.00 \pm 0.00^{\mathrm{b}}$ & $7.10 \pm 0.13^{\mathrm{a}}$ & $0.00 \pm 0.00^{\mathrm{b}}$ & $0.00 \pm 0.00^{\mathrm{b}}$ \\
\hline Leucine & $8.40 \pm 0.13^{\mathrm{a}}$ & $0.00 \pm 0.00^{c}$ & $0.82 \pm 1.15^{\mathrm{b}}$ & $8.48 \pm 0.15^{\mathrm{a}}$ & $0.00 \pm 0.00^{c}$ & $0.00 \pm 0.00^{c}$ \\
\hline Threonine & $4.78 \pm 0.44^{b}$ & $11.69 \pm 7.34^{\mathrm{a}}$ & $10.13 \pm 8.24^{\mathrm{a}}$ & $5.54 \pm 2.82^{\mathrm{b}}$ & $5.63 \pm 6.89^{b}$ & $5.44 \pm 7.69^{b}$ \\
\hline Serine & $4.52 \pm 0.74^{b}$ & $11.66 \pm 5.54^{\mathrm{a}}$ & $23.77 \pm 1.36^{\mathrm{a}}$ & $5.60 \pm 2.20^{\mathrm{b}}$ & $2.75 \pm 3.88^{c}$ & $6.73 \pm 9.51^{b}$ \\
\hline Proline & $7.16 \pm 0.49^{a}$ & $0.00 \pm 0.00^{c}$ & $0.85 \pm 1.20^{\mathrm{b}}$ & $6.84 \pm 0.13^{\mathrm{a}}$ & $0.00 \pm 0.00^{c}$ & $0.00 \pm 0.00^{c}$ \\
\hline Aspartic Acid & $9.17 \pm 0.81^{\mathrm{a}}$ & $0.00 \pm 0.00^{c}$ & $0.39 \pm 0.56^{\mathrm{b}}$ & $6.04 \pm 0.41^{\mathrm{a}}$ & $0.00 \pm 0.00^{c}$ & $0.00 \pm 0.00^{c}$ \\
\hline Glutamic Acid & $7.69 \pm 0.90^{\mathrm{a}}$ & $0.00 \pm 0.00^{\mathrm{b}}$ & $0.00 \pm 0.00^{\mathrm{b}}$ & $8.40 \pm 1.29^{\mathrm{a}}$ & $0.00 \pm 0.00^{\mathrm{b}}$ & $0.00 \pm 0.00^{\mathrm{b}}$ \\
\hline Phenylalanine & $4.85 \pm 0.19^{\mathrm{a}}$ & $2.88 \pm 4.07^{\mathrm{b}}$ & $0.53 \pm 0.75^{\mathrm{c}}$ & $2.83 \pm 0.12^{\mathrm{b}}$ & $1.73 \pm 2.45^{b}$ & $0.00 \pm 0.00^{\mathrm{d}}$ \\
\hline Lysine & $6.08 \pm 0.65^{\mathrm{a}}$ & $2.28 \pm 3.22^{\mathrm{b}}$ & $2.97 \pm 3.20^{\mathrm{b}}$ & $5.29 \pm 2.50^{\mathrm{a}}$ & $2.62 \pm 3.71^{b}$ & $0.00 \pm 0.00^{\mathrm{a}}$ \\
\hline Histidine & $4.75 \pm 3.05^{\mathrm{a}}$ & $0.00 \pm 0.00^{\mathrm{d}}$ & $1.30 \pm 1.83^{\mathrm{b}}$ & $3.93 \pm 2.65^{\mathrm{a}}$ & $0.53 \pm 0.74^{\mathrm{c}}$ & $1.46 \pm 2.53^{\mathrm{b}}$ \\
\hline Tyrosine & $3.26 \pm 0.76^{\mathrm{a}}$ & $2.53 \pm 3.58^{\mathrm{a}}$ & $1.41 \pm 1.38^{\mathrm{b}}$ & $3.19 \pm 1.80^{\mathrm{a}}$ & $1.74 \pm 2.46^{\mathrm{b}}$ & $0.00 \pm 0.00^{\mathrm{c}}$ \\
\hline
\end{tabular}


Table 5: SDS-page densitometry analysis of protein (\%) from spent cricket, locust and silkworm powder following one-step organic solvent extraction with various organic solvents

\begin{tabular}{|c|c|c|c|c|c|}
\hline \multicolumn{6}{|l|}{ A. Cricket } \\
\hline $\begin{array}{l}\text { Standard } \\
(\mathbf{k D})\end{array}$ & Hexane & Chloroform & $\begin{array}{c}\text { Chloroform- } \\
\text { Methanol }\end{array}$ & $\begin{array}{l}\text { Methyl-Tert- } \\
\text { Butyl-Ether }\end{array}$ & $\begin{array}{c}\text { Hexane- } \\
\text { Isopropanol }\end{array}$ \\
\hline 20 & $13.20 \pm 7.33^{\mathrm{a}}$ & $9.61 \pm 5.44^{\mathrm{a}}$ & $9.83 \pm 8.91^{\mathrm{a}}$ & $11.28 \pm 14.93^{\mathrm{a}}$ & $19.56 \pm 18.20^{\mathrm{a}}$ \\
\hline 25 & $18.94 \pm 3.48^{\mathrm{a}}$ & $12.06 \pm 4.94^{\mathrm{a}, \mathrm{b}}$ & $4.34 \pm 1.76^{\mathrm{b}, \mathrm{c}}$ & $3.02 \pm 2.57^{\mathrm{c}}$ & $16.93 \pm 10.57^{\mathrm{a}, \mathrm{b}, \mathrm{c}}$ \\
\hline 50 & $13.42 \pm 3.14^{\mathrm{c}}$ & $29.23 \pm 4.36^{\mathrm{a}}$ & $10.15 \pm 3.47^{\mathrm{c}}$ & $9.94 \pm 6.11^{\mathrm{c}}$ & $17.37 \pm 5.52^{\mathrm{b}}$ \\
\hline 75 & $19.23 \pm 7.00^{\mathrm{a}}$ & $11.29 \pm 1.22^{\mathrm{a}, \mathrm{b}}$ & $12.72 \pm 7.11^{\mathrm{a}, \mathrm{b}}$ & $7.24 \pm 5.84^{\mathrm{b}}$ & $9.54 \pm 5.43^{b}$ \\
\hline 150 & $45.50 \pm 8.87^{\mathrm{a}}$ & $29.3 \pm 5.02^{\mathrm{a}}$ & $32.38 \pm 4.73^{\mathrm{a}}$ & $39.8 \pm 12.45^{\mathrm{a}}$ & $9.61 \pm 5.23^{\mathrm{a}}$ \\
\hline \multicolumn{6}{|l|}{ B. Locust } \\
\hline $\begin{array}{c}\text { Standard } \\
(\mathrm{kD})\end{array}$ & Hexane & Chloroform & $\begin{array}{c}\text { Chloroform- } \\
\text { Methanol } \\
\end{array}$ & $\begin{array}{l}\text { Methyl-Tert- } \\
\text { Butyl-Ether }\end{array}$ & $\begin{array}{c}\text { Hexane- } \\
\text { Isopropanol }\end{array}$ \\
\hline 50 & $18.47 \pm 3.88^{a}$ & $21.93 \pm 0.87^{\mathrm{a}}$ & $32.76 \pm 5.86^{\mathrm{a}}$ & $17.61 \pm 4.67^{\mathrm{a}}$ & $11.55 \pm 4.91^{\mathrm{a}}$ \\
\hline 75 & $17.41 \pm 2.64^{\mathrm{a}}$ & $11.54 \pm 6.47^{\mathrm{a}}$ & $15.61 \pm 5.94^{\mathrm{a}}$ & $11.83 \pm 1.95^{\mathrm{a}}$ & $26.83 \pm 7.01^{\mathrm{a}}$ \\
\hline 100 & $32.16 \pm 7.51^{\mathrm{a}, \mathrm{b}}$ & $16.80 \pm 3.84^{\mathrm{a}, \mathrm{b}}$ & $14.19 \pm 5.40^{\mathrm{b}}$ & $44.83 \pm 10.13^{\mathrm{a}}$ & $37.19 \pm 2.62^{\mathrm{a}}$ \\
\hline 150 & $38.92 \pm 2.37^{\mathrm{a}}$ & $10.72 \pm 11.14^{\mathrm{a}}$ & $29.61 \pm 4.50^{\mathrm{a}}$ & $5.50 \pm 0.79^{\mathrm{a}}$ & $6.96 \pm 5.28^{\mathrm{a}}$ \\
\hline \multicolumn{6}{|c|}{ C. Silkworm } \\
\hline $\begin{array}{c}\text { Standard } \\
(\mathrm{kD})\end{array}$ & Hexane & Chloroform & $\begin{array}{c}\text { Chloroform- } \\
\text { Methanol } \\
\end{array}$ & $\begin{array}{l}\text { Methyl-Tert- } \\
\text { Butyl-Ether }\end{array}$ & $\begin{array}{c}\text { Hexane- } \\
\text { Isopropanol }\end{array}$ \\
\hline 20 & $17.88 \pm 6.57^{\mathrm{a}}$ & $15.09 \pm 6.60^{\mathrm{a}}$ & $14.46 \pm 7.24^{\mathrm{a}}$ & $14.29 \pm 4.22^{\mathrm{a}}$ & $15.67 \pm 6.02^{\mathrm{a}}$ \\
\hline 37 & $20.59 \pm 7.83^{\mathrm{a}}$ & $42.46 \pm 1.82^{\mathrm{a}}$ & $13.41 \pm 4.48^{\mathrm{a}}$ & $34.27 \pm 1.83^{\mathrm{a}}$ & $12.57 \pm 4.71^{\mathrm{a}}$ \\
\hline 50 & $19.77 \pm 6.24^{\mathrm{a}, \mathrm{b}}$ & $0.51 \pm 4.03^{\mathrm{a}, \mathrm{b}}$ & $6.34 \pm 2.14^{\mathrm{b}}$ & $12.26 \pm 5.93^{\mathrm{a}, \mathrm{b}}$ & $16.79 \pm 1.23^{\mathrm{a}}$ \\
\hline 75 & $16.58 \pm 5.29^{\mathrm{a}, \mathrm{b}}$ & $15.06 \pm 4.03^{\mathrm{a}, \mathrm{b}}$ & $47.99 \pm 8.41^{\mathrm{a}}$ & $16.1 \pm 8.53^{\mathrm{a}, \mathrm{b}}$ & $9.01 \pm 3.08^{b}$ \\
\hline 100 & $8.48 \pm 4.05^{\mathrm{a}}$ & $9.20 \pm 0.47^{\mathrm{a}}$ & $17.88 \pm 6.57^{\mathrm{a}}$ & $9.36 \pm 6.39^{\mathrm{a}}$ & $9.44 \pm 3.26^{\mathrm{a}}$ \\
\hline
\end{tabular}

